\title{
DEFERENCE IS DEAD (LONG LIVE CHEVRON)
}

\author{
Nathan Richardson*
}

Chevron U.S.A. v. Natural Resources Defense Council has stood for more than 35 years as the central case on judicial review of administrative agencies' interpretations of statutes. Its contours have long been debated, but more recently it has come under increasing scrutiny, with some - including two sitting Supreme Court justices - calling for the case to be overturned. Others praise Chevron, calling deference necessary or even inevitable. All seem to agree the doctrine is powerful and important.

This standard account is wrong, however. Chevron is not the influential doctrine it once was and has not been for a long time. It has been eroded from the outside as a series of exclusions have narrowed its scope, and has been hollowed out from the inside as Justices have become ever more willing to find clear meaning in statutes, thereby denying deference to agencies. In recent years, agencies have won only a handful of statutory interpretation cases, and none in more than four years. Only once since 2015 has deference been outcome-determinative. At the Supreme Court level (though not, for now, in the circuit courts), deference is dead. The once-crystal Chevron has turned to mud. As a result, however, it is less likely to be formally overturned than widely believed - critics of deference and of administrative power on the Court would gain little. Instead, Chevron's future is likely to be one of further decline, at least in the short term. This has implications for major policy areas like climate change, health care, and immigration where regulatory policy is necessary and challenges are likely to reach the Court.

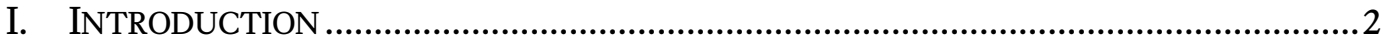

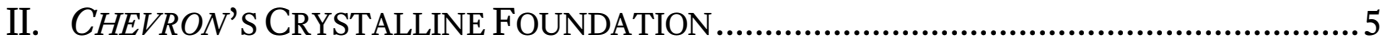

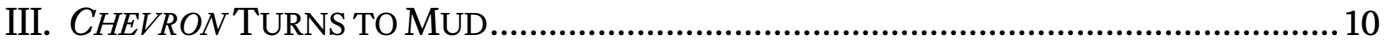

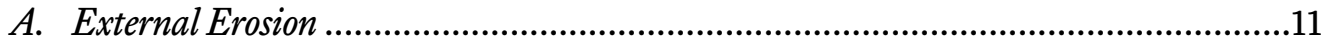

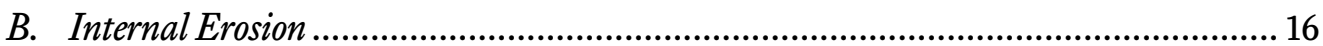

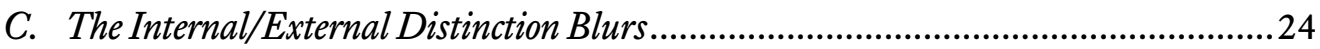

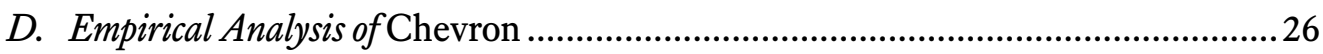

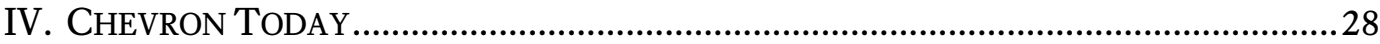

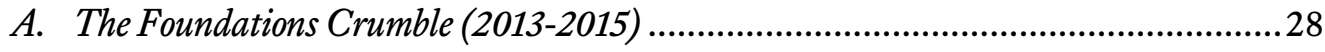

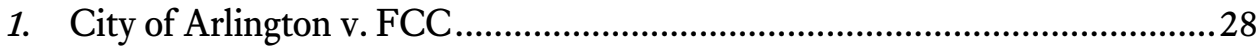

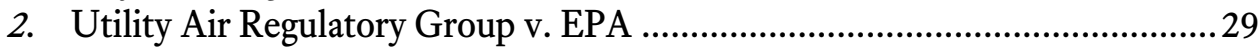

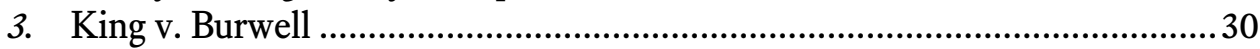

\footnotetext{
* Associate Professor, University of South Carolina. The suggestions and encouragement of my colleagues, including but not limited Shelley Welton, Derek Black, and Josh Eagle, were highly valuable. Special thanks to C.F., without whose help this project would have been impossible to complete. Thanks also to Kent Barnett, Tejas N. Narechania, William Yeatman, and many others for their comments and suggestions, large and small.
} 


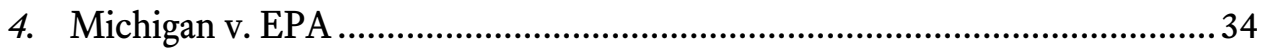

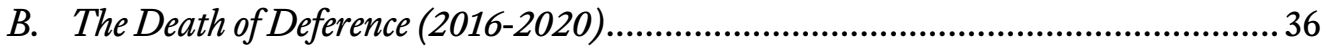

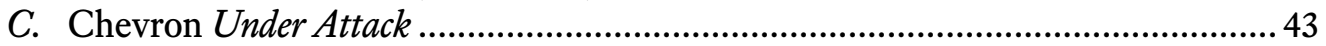

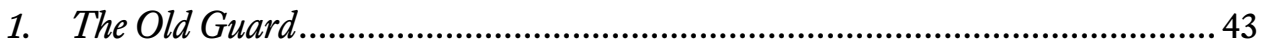

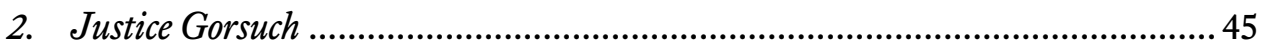

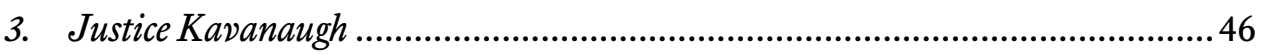

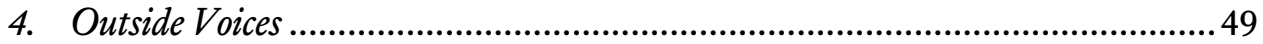

D. Effects of Chevron's Decline at Agencies ............................................................50

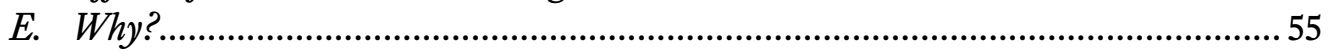

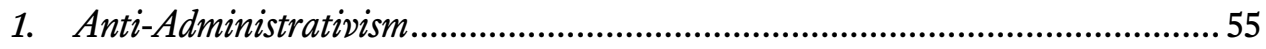

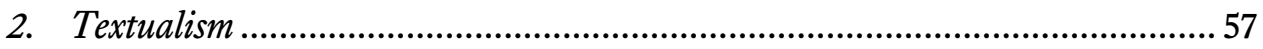

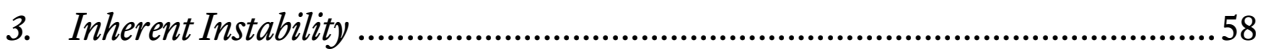

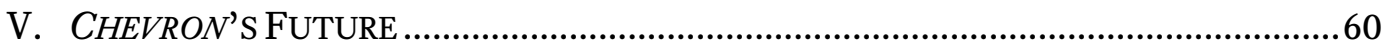

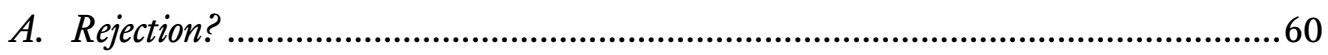

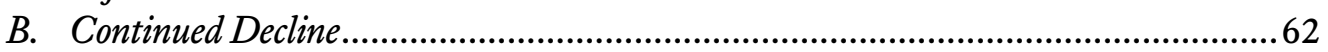

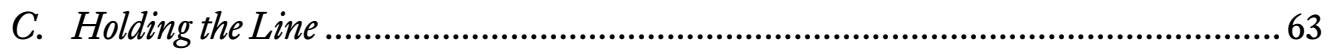

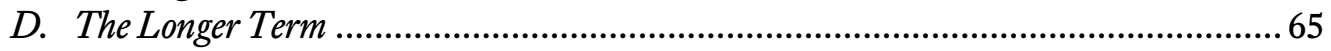

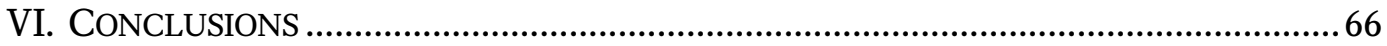

\section{INTRODUCTION}

Administrative law is a delicate balance of power between Congress, agencies, and the courts. Congress is ultimately in charge-the statutes it enacts are agencies' sole source of authority. ${ }^{1}$ But Congress acts only rarely, and when it does, leaves substantial gaps. The tasks of identifying the scope of those gaps, and defining the powers agencies have to fill them (or not), are left to the courts and the agencies themselves. ${ }^{2}$ In the modern era, the central case defining this balance of interpretive power between agencies and courts has of course been Chevron v. NRDC, decided by the Supreme Court in $1984 .{ }^{3}$ Chevron has been so influential for so long because it crystallized a central question in administrative law (when courts would defer to agency interpretations of statutes), replacing fuzzy,

\footnotetext{
${ }^{1}$ See Michael P. Healy, Reconciling Chevron, Mead, and the Review of Agency Discretion: Source of Law and the Standards of Judicial Review, 19 GEO. MASON L. REV. 1, 9 (2011) ("Skidmore and Armour established early on in the administrative era that Congress plays the critical role of providing clear statutory meaning when it wishes to do so, and binds both courts and agencies in that situation.").

${ }^{2}$ Or, perhaps more precisely, these tasks are the province of interest groups, bureaucrats, and other political actors acting within, exerting influence from outside, and litigating against agencies.

${ }^{3}$ Chevron U.S.A. Inc. v. Nat. Res. Def. Council, Inc., 467 U.S. 837 (1984).
} 
multifactor standards with rule-like clarity, at least in a broad swath of cases. ${ }^{4}$ Chevron's reputation for influence is nearly unsurpassed in the administrative law canon; Cass Sunstein elevated Chevron to the highest of pedestals, calling it a "counter-Marbury for the administrative state." 5

But at the Supreme Court level Chevron now lacks the power and predictability it claims to have (and may once have had, though it probably never had the influence its reputation suggests). This decline in Chevron's influence dates back to at least the 1990s, but has accelerated: over the past five terms, agencies have won only 3 of 15 statutory interpretation cases, and in only one of those three did Chevron matter (i.e. the Court deferred to the agency's interpretation). ${ }^{6}$ Moreover, Chevron appears under threat. Prominent judges and academics, including two sitting Supreme Court Justices, have called for its reconsideration and possible rejection. ${ }^{7}$ Whether it will survive, and for how long, is an open question.

As Michael Herz concluded almost five years ago, "[a]t this point, it takes chutzpah to write about Chevron." ${ }^{8}$ Nevertheless, since then debate over Chevron (and predictions of its demise) seem to have increased in volume. But perhaps there is room to say a bit more. I am not the first to note Chevron's decline. Among academics, Linda Jellum in $2006^{9}$ and Michael Herz in 2015, ${ }^{10}$ and Jonathan Adler in 2017, ${ }^{11}$ among others, have noted aspects of the decline of meaningful Chevron deference at the Court. There are contrary views: Nicholas Bednar \& Kristin Hickman in 2017, ${ }^{12}$ and Adrian Vermeule in a 2016 book $^{13}$ have argued that deference retains vitality and is even inevitable. Christopher Walker and Kent Barnett have documented that Chevron retains influence in the lower courts, at least for now ${ }^{14}$ the claims made here are exclusively about the doctrine's present and future at the Supreme Court level, though they may trickle down to lower courts over time.

This article makes three new contributions to this literature. First, it catalogs the role of Chevron at the Court in recent years; this evidence, detailed in Section IV, lends support

${ }^{4}$ See Ronald J. Krotoszynski, Why Deference?: Implied Delegations, Agency Expertise, and the Misplaced Legacy of Skidmore, 54 ADMIN. L. REv. 735, 742 (2002); see also United States v. Mead Corp., 533 U.S. 218, 241 (2001) (Scalia, J., dissenting) ("[T] he Court now resurrects, in full force, the pre-Chevron doctrine of Skidmore deference ... whereby ' $[\mathrm{t}]$ he fair measure of deference to an agency administering its own statute ... var[ies] with circumstances,' ... The Court has largely replaced Chevron, in other words, with that test most beloved by a court unwilling to be held to rules (and most feared by litigants who want to know what to expect): th'ol' 'totality of the circumstances' test.").

${ }^{5}$ See Cass R. Sunstein, Law and Administration after Chevron, 90 Colum. L. REv. 2071, 2075 (1990).

${ }^{6}$ See data and discussion infra Section IV.B.

${ }^{7}$ See discussion infra Section IV.C.

${ }^{8}$ Herz, supra note 10, at 1867.

${ }^{9}$ Linda Jellum, Chevron's Demise: A Survey of Chevron from Infancy to Senescence, 59 ADMIN. L. REV. 725 (2007).

${ }^{10}$ Michael Herz, Chevron is Dead; Long Live Chevron, 115 Colum. L. Rev. 1867 (2015).

${ }^{11}$ Jonathan H. Adler, Restoring Chevron's Domain, 81 Mo. L. REV. 983 (2016).

${ }^{12}$ Nicholas R. Bednar \& Kristin E. Hickman, Chevron's Inevitability, 85 GEO. WASH. L. REV. 1392 (2017).

${ }^{13}$ See generally AdRIAN VERMEULE, LAW's ABNEGATION: From LAW's EMPIRE TO THE AdMINISTRATIVE STATE (2016).

${ }^{14}$ Kent H. Barnett \& Christopher J. Walker, Chevron in the Circuit Courts, 116 Mich. L. Rev. 1 (2016). 
to the thesis that deference has declined precipitously. Second, it adopts a model for understanding Chevron's rise and fall: Carol Rose's metaphor of legal "crystals" and "mud", which predicts a cyclical pattern, from consolidation and simplification to complexity and ambiguity. ${ }^{15}$ This model suggests Chevron's decline was probably inevitable. Finally, the Article (in Section V) makes and justifies a prediction that despite its weakness, Chevron is unlikely to be overturned, and suggests some plausible futures for the doctrine.

At the Supreme Court level, Chevron's ability to provide certainty has been on the wane for more than two decades. To be sure, Chevron remains a near-necessary citation in administrative law cases, retains a central position in administrative law curricula, and persists as one of the most well-known and cited cases in American law. But at the Supreme Court level, Chevron today applies to an ever-shrinking range of cases, has little impact on the outcome of cases to which it still applies, and is of little use as a predictive tool for future disputes. In short Chevron's crystal has turned to mud. Agencies before the Supreme Court in recent years appear to receive little or no interpretive deference, whatever Chevron says. In my view it is fair to say that deference is dead at the Supreme Court, though it is worth noting that lower courts and agencies do not seem to have followed, at least not yet. ${ }^{16}$

This erosion of Chevron's rule-like character has been at times explicit, and at times implicit. First, the Supreme Court's has established a series of explicit carve-outs from Chevron's scope. Agency interpretations of criminal law, interpretations of statutes empowering multiple agencies, and so-called "major questions", among other classes of cases, have been excluded from Chevron deference. Second, the Court has at times given little more than lip service to Chevron's deference requirement, implicitly eroding its scope and reliability. These trends have been present for a long time, perhaps all the way back to Chevron itself. But they have accelerated in recent cases. Taken together, they mean agencies are entitled to deference in a shrinking pool of cases, with fuzzy boundaries, and that deference is weaker and more uncertain even when the Court purports to give it. In short, not only has the Court's interpretive deference to agencies declined over time, but also (and possibly more importantly) the predictability and reliability of that deference has declined as well.

But these developments do not mean Chevron is likely to be overruled. That can't be ruled out, but erosion of Chevron's force and clarity - its muddying-make it less likely, not more. The reasons why are explored below, but they boil down to a simple idea: Why go to the effort to overrule a case that isn't very important anymore? The Court has already shown Chevron is rarely an obstacle and, when it is, that its scope can be shrunk, or mandate weakened so as to render it toothless. Chevron deference will continue to be cited when judges find it helpful (or convenient) to do so, but its ability to decide cases is rapidly diminishing, if it has not disappeared already. Perhaps one day Chevron will be replaced

\footnotetext{
${ }^{15}$ See generally Carol Rose, Crystals and Mud in Property Law, 40 STAN. L. REV. 577 (1988).

${ }^{16}$ See Barnett \& Walker, supra note 14.
} 
with a new deference rule, but for now the pressure appears to be in the opposite direction - toward more doctrinal uncertainty, not less. ${ }^{17}$

This is a positive claim, not a normative one. In the interest of full disclosure, my view is that in the short term Chevron's decline will lead to greater judicial involvement in policy matters, and I am not optimistic that will lead to better results. In the longer term, whether muddying of deference doctrine is good depends on how and when it recrystallizes again, a topic I speculate about at the end of this article. But I hope here only to persuade that my positive claim is true-that Chevron is far less meaningful than it is widely understood to be, but is nevertheless likely to survive - so that a normative debate over that (and what should follow) can be had.

\section{CHEVRON'S CRYSTALLINE FOUNDATION}

Though Chevron is likely familiar to most readers, it's worth briefly reviewing what it does. Federal administrative agencies are empowered by Congress to do a wide variety of things: environmental regulation, immigration enforcement, provision of benefits, the list is nearly endless. The statutes by which Congress empowers agencies to do these things are complex, and not everyone may agree about what they allow or require agencies to do or refrain from doing; gaps are inevitable. To do their work, agencies must try to fill these gaps. If their actions (or inactions) are challenged in court, judges must then decide if the agency's interpretation of the statute is correct. Chevron is the most important in a series of Supreme Court cases over at least 75 years dealing with how much weight judges should give to the agency's statutory interpretation.

Chevron did (at least) two things. Its first and probably most well-known effect was to shift power from courts to agencies by creating a space within which judges were required to defer to agency interpretations of statutes. ${ }^{18}$ Only if those interpretations contradicted discernible and clear Congressional intent (so-called Chevron Step One), or exceeded the bounds of reasonableness (so-called Step Two), would judges be permitted to replace the agency's interpretation with their own. ${ }^{19}$ Chevron's second innovation was to crystallize the law of deference to agency interpretations, at least in part. Before Chevron, agencies were treated more or less like any party before the court and given an opportunity (but no more) to convince the judges of the wisdom of their position..$^{20}$ Chevron changed thatwhere before there were standards, now there was a rule (defer to agency interpretations),

\footnotetext{
${ }^{17}$ Like any predictions about the Court, these depend on its ideological balance remaining stable; if there are major personnel changes on the Court, all bets are off.

${ }^{18}$ See Sunstein, supra note 5, at 2074-75.

${ }^{19}$ See Antonin Scalia, Judicial Deference to Administrative Interpretations of Law, 1989 DUKE L.J. 511, 51112.

${ }^{20}$ See Cass R. Sunstein, Chevron Step Zero, 92 VA. L. REv. 187, 211 (2006) ("[T] suggested that courts would merely consult such agency interpretations, considering whether they were longstanding, consistent, and well-reasoned.").
} 
at least within some range of cases. ${ }^{21}$ These two changes wrought by Chevron are inextricably intertwined; to the extent that Chevron shifted power from courts to agencies, it was in large part by giving agencies more certainty that their interpretations would be upheld.

Chevron quickly became recognized as a major doctrinal shift in administrative law. ${ }^{22}$ But in a broader sense it was nothing new. Across all areas of law, there is evolution from rules to standards and back or, as Carol Rose described it in a seminal article on the pattern in property law contexts, from "crystals" to "mud" (and back). ${ }^{23}$ Rose's framework is useful not just because it is earthily evocative, but because it is far more precise than the perhaps overexposed rules/standards dichotomy. ${ }^{24}$

To take one of Rose's illustrations, the "crystal" caveat emptor rule has been muddied by modern doctrines requiring disclosure of defects by sellers and imposing an implied warranty of habitability on landlords. But private parties have responded by sometimes including waivers of these duties in contracts (reimposing the crystalline rule). Then courts or legislatures may respond by making certain duties nonwaivable, and on the pattern continues. ${ }^{25}$

Both crystal rules and muddy standards have advantages, which become more apparent the more the legal pendulum swings in the opposite direction. Crystals make for settled expectations, allowing long-term planning and predictable outcomes. Muddy standards allow for case by case determinations, taking account of unique circumstances. They are less vulnerable to exploitation by bad actors who technically comply with rules, and able to deal with unanticipated contradictions or superseding concerns. The appeal of both leads to oscillation. Make the rules too crystallized, and outlier cases will make muddying the waters with exceptions very tempting. Then as the rules are overlaid with those exceptions and epicycles, decision costs go up and predictability declines, making the case for "rationalization" - the re-imposition of rules (though the new rules may be quite different from the old). ${ }^{26}$ This description suggests that the move from crystals to mud and back is endogenous, but external factors might come into play as well. For example, pressure to change might come from perception that some actors are taking advantage of current law,

\footnotetext{
${ }^{21}$ See Scalia, supra note 19, at 511 (Chevron "announced the principle that the courts will accept an agency's reasonable interpretation of the ambiguous terms of a statute that the agency administers." (emphasis added)).

${ }^{22}$ See generally id.; see also Stephen Breyer, Judicial Review of Questions of Law and Policy, 38 ADMIN. L. REV. 363 (1986).

${ }^{23}$ See Rose, supra note 15, at 595 (drawing on the work of historian P.S. Atiyah to suggest that law evolves from mud to crystal and back, cyclically).

${ }^{24}$ See Pierre Schlag, Rules and Standards, 33 UCLA L. REV. 379, 380 (1985) (suggesting that "much of legal discourse (including the very fanciest law-talk) might be nothing more than the unilluminating invocation of 'canned' pro and con arguments about rules and standards.").

${ }^{25}$ See Rose, supra note 15 , at 581-83.

${ }^{26} I d$. at $590-93$.
} 
or that it does not adequately protect groups or interests who lacked political power in the past. $^{27}$

Chevron fits this mud-to-crystal pattern well, even if it didn't go all the way. The Skidmore standard that prevailed before 1984 required judges to consider a wide (and nonexclusive) set of factors when deciding whether to defer to agency interpretations of law, including the consistency of the agency's position, the agency's level of expertise, and the interpretation's "power to persuade." ${ }^{28}$ It would be hard to sketch a looser standard, and in practice Skidmore deference was probably little different from de novo review, with agencies cast as "little more than expert witnesses." ${ }^{29}$ Each case, and each agency interpretation of a statute, would be evaluated by judges on its own merits. There were no hard rules, only loose standards.

In contrast, Chevron demanded deference to agency interpretations from judges, at least in the range of cases where Congressional intent was clear. Perhaps unintentionally, ${ }^{30}$ it does (or at least $\mathrm{did}$ ) something quite radical: after Chevron, judges were now required to accept some agency interpretations they felt were wrong, or at least inferior. ${ }^{31}$ As Justice Kavanaugh has put it,

[W]hen the Executive Branch chooses a weak (but defensible) interpretation of a statute, and when the courts defer, we have a situation where every relevant actor may agree that the agency's legal interpretation is not the best, yet that interpretation carries the force of law. Amazing. ${ }^{32}$

Chevron did not go as far as it might have. A fully crystalline solution to the question of interpretive authority would be to simply say that agencies always win. But of course that would make courts impotent in many administrative law cases, violating both Marbury ${ }^{33}$ and Article III. ${ }^{34}$

${ }^{27}$ This could prompt change in either direction. If current law is rule-like and the apparent threat is from actors that technically comply but violate the spirit of the law (or other important norms), then a move toward mud would allow decisionmakers to catch bad behavior. On the other hand, if actors are perceived to be taking advantage of uncertain standards to decide cases arbitrarily, or in line with their preferences, then a more crystalline law could prevent that.

${ }^{28}$ Skidmore v. Swift \& Co., 323 U.S. 134, 140 (1944).

${ }^{29}$ See Jellum, supra note 9 , at 738.

${ }^{30}$ See Thomas W. Merrill, The Story of Chevron: The Making of an Accidental Landmark, 66 ADMIN. L. REV. 253, 275 (2014) (noting that the parties, attorneys, and Justices, including its author Justice Stevens, did not view Chevron as a landmark case or doctrinal change when it was decided).

${ }^{31}$ See Breyer, supra note 22, at 379.

32 Brett Kavanaugh, Fixing Statutory Interpretation, 129 HARV. L. REV. 2118, 2151 (2016) (reviewing Robert A. KATZMANN, Judging STATUTES (2014)).

${ }^{33} 5$ U.S. (1 Cranch) 137, 177 (1803) ("It is emphatically the province of the judicial department to say what the law is.").

${ }^{34}$ U.S. ConsT. art. III, $§ 1$ ("The judicial Power of the United States, shall be vested in one supreme Court, and in such inferior Courts as the Congress may from time to time ordain and establish."). 
Instead, Chevron takes a more constrained approach: judges first decide if statutory ambiguity exists. If not, i.e., if "Congress has directly spoken," there is no deference. ${ }^{35}$ If ambiguity does exist, then judges are directed to defer to the agency interpretation, at least within reason. ${ }^{36}$ Skidmore's multifactor inquiry is collapsed to a single question, whose outcome (in theory) determines the case. If there is no ambiguity, the agency's expertise, power to persuade, and the other factors are irrelevant and the agency loses. If there is ambiguity, those factors are either similarly irrelevant, or nearly so, and the agency almost always wins. ${ }^{37}$ This clarity and brevity are hallmark legal crystallization, even if they don't go all the way.

To be sure, Chevron was never fully crystalline. It never dictated the outcome of all cases. Its innovation-deference-only applies when a court finds statutory ambiguity. Even when it does apply, it only shifts decisionmaking authority to another body (the agency), rather than dictating a substantive result. And even then it only shifts that authority within some range of "reasonableness" (though, again, Step Two is so deferential that at the Supreme Court level as to be nearly irrelevant)..$^{38}$

That said, Chevron never had a golden age of clarity; in characterizing it as a crystallization I do not mean to imply that it did. It took the Court years to figure out what it meant, ${ }^{39}$ and by that time it was already being constrained and reshaped, as the next Section details. It is plausible, therefore, to call Chevron a failed attempt at crystallization. Linda Jellum does so, arguing that "the opinions of the late 1980s and 1990s show a court divided and confused by Chevron.... There is no consistency, just a muddy battlefield." 40 If this view is correct, then Chevron did little: Skidmore deference was a muddy mess, Chevron was too, and that remains the case today.

In my view this goes too far, or was at least premature. Jellum's characterization is largely driven by a doctrinal fight within Chevron that she observes and documents between

35 Chevron U.S.A. Inc. v. Nat. Res. Def. Council, Inc., 467 U.S. 837, 842 (1984). As Chevron cases illustrate, this inquiry is far more complex than it appears. Is the question whether the text or Congress' intent is clear? What tools can be brought to bear to resolve any apparent ambiguity? See Jellum, supra note 9, at 727.

36 This "reasonableness" standard in Chevron's "second step" probably collapses into traditional arbitrary and capricious review, see Matthew C. Stephenson \& Adrian Vermeule, Chevron Has Only One Step, 95 VA. L. REV. 597, 598 (2008).

37 See Stephen Breyer et al., Administrative LaW and Regulatory Policy 319 (8th ed. 2017) (“In practice, it is rare for a court to set aside an agency interpretation in step two. By most counts, the Supreme Court has done so only twice."). See also VERMEULE, supra note 13, at 158 ("At [the Supreme Court] level, agencies almost never lose [arbitrariness challenges]," within which Vermeule includes Chevron Step Two cases. Since 1982, he finds, "the Court has passed on the merits of arbitrariness challenges sixty-four times. Of those, agencies have lost ... only five times - a remarkable win rate of 92 percent.").

${ }^{38}$ See VERMEULE, supra note 13 , at 158.

${ }^{39}$ As noted above, Justice Stevens claims not to have intended a revolutionary doctrinal change when he wrote the majority opinion in Chevron. See Merrill, supra note 30, at 275. Linda Jellum describes the process by which the Court came to grips with Chevron's import. See Jellum, supra note 9, at 743-53. Articles by Justices Scalia and Breyer not long after Chevron was decided were particularly influential. See Scalia, supra note 19; Breyer, supra note 22.

${ }^{40}$ Jellum, supra note 9, at 760. 
textualist and "intentionalist" views on what interpretive tools can be used to determine whether statutory ambiguity exists. ${ }^{41}$ This dispute is important for understanding Chevron deference, and I agree that the rise of textualism plays an important role in Chevron's decline over the long term. ${ }^{42}$ But the 1980s-90s disputes she discusses do not affect the basic crystallization that Chevron achieved; and even if they did, it was temporary-as Jellum describes, the textualists won. ${ }^{43}$ Jellum's characterization of early Chevron as "muddy" is also driven by the court's 1994 decision in MCI Telecommunications v. ATET; for reasons detailed in the next Section I agree that this case substantially undercut Chevron by narrowing its scope.

The inconsistent application and internal conflict that mark the Court's early Chevron cases don't change the fact that it was a significant step toward crystallization, relative to what preceded it. Jellum does not appear to disagree; she notes that " $[\mathrm{p}]$ rior to Chevron, not every agency opinion was entitled to deference. But Chevron established an all-ornothing default rule." ${ }^{44}$ This is easier to see if one steps back from the wider fight over textualism at the time (within which Chevron cases were an inevitable battlefield). Justice Scalia was nominated to the Court in 1986, and quickly became an ardent Chevron supporter..$^{45} \mathrm{He}$ was soon followed by five other new Justices over the next 8 years, radically changing the makeup of the Court. For this new Court, Chevron was the bedrock case in its domain (agency interpretation of statutes). ${ }^{46}$ The law (or at least the Court) was ready for crystallization. Over time, Chevron became foundational, even "quasi-constitutional," "the undisputed starting point for any assessment of the allocation of authority between federal courts and administrative agencies." 47

It appears to have changed outcomes, too. Agencies won cases more often under Chevron than under the preceding Skidmore regime, to a small but still significant degree. ${ }^{48}$ Probably more importantly, agencies could also now have real confidence judges would uphold their interpretations, at least within some range. Review of agency decisions became

${ }^{41} I d$. at $753-60$.

${ }^{42}$ See infra discussion Section IV.E.2.

${ }^{43}$ Jellum, supra note 9 , at 761.

${ }^{44} I d$. at 743 .

${ }^{45}$ See Scalia, supra note 19, at 521 ("I tend to think, however, that in the long run Chevron will endure and be given its full scope - not so much because it represents a rule that is easier to follow and thus easier to predict (though that is true enough), but because it more accurately reflects the reality of government, and thus more adequately serves its needs.").

${ }^{46}$ Jellum, supra note 9, at 748-60.

${ }^{47}$ Sunstein, supra note 20 , at 188.

${ }^{48}$ See William N. Eskridge \& Lauren E. Baer, The Continuum of Deference: Supreme Court Treatment of Agency Statutory Interpretations from Chevron to Hamdan, 96 GEO. L.J. 1083, 1099-1100 (2008) (finding a 76.2\% win rate for agencies in Supreme Court cases through 2006 under Chevron deference, versus a 73.5\% win rate under Skidmore and an overall win rate of 68.3\%). See infra Section III.D, for a discussion of this and other empirical analyses of Chevron. 
more predictable, allowing agencies to experiment more with new regulatory approaches. ${ }^{49}$ With the confidence that litigation outcomes are more predictable, agencies can better know (or, more precisely, themselves better define) the limits of their authority. ${ }^{50}$ In short, Chevron significantly empowered the executive branch at the judiciary's expense. ${ }^{51}$ As Justice Kavanaugh put it (while criticizing Chevron),

In many ways, Chevron is nothing more than a judicially orchestrated shift of power from Congress to the Executive Branch.... From my more than five years of experience at the White House, I can confidently say that Chevron encourages the Executive Branch (whichever party controls it) to be extremely aggressive in seeking to squeeze its policy goals into ill-fitting statutory authorizations and restraints. ${ }^{52}$

Within a few years, a core question in administrative law-interpretive deference to agencies - had been crystallized, shifting power seemingly permanently toward agencies and away from courts.

\section{CHEVRON TURNS TO MUD}

Nearly as rapidly, however, Chevron's crystal started to erode. Within a few years after Chevron was decided, the Supreme Court began to add exceptions to its reach, and additional exceptions have been added over time. Students and practitioners must now master a complex list of carve-outs, with litigants predictably arguing as much about whether a case falls into one of the exceptions as they do about Chevron's core inquiry about statutory clarity.

Over the same period, the Supreme Court has by fits and starts reduced the degree of deference shown in those cases that remain within Chevron's scope-justices seem increasingly willing to find that a statute is clear (i.e. that Congress has spoken to the issue), and that therefore agency interpretations can be rejected at Chevron's "Step One." And on a small number of recent occasions agencies have also lost cases at Chevron's "Step 2";

${ }^{49}$ Sunstein, supra note 20, at 190 ("Chevron has signaled a substantial increase in agency discretion to make policy through statutory interpretation. For this reason, Chevron might well be seen not only as a kind of counter-Marbury, but even more fundamentally as the administrative state's very own McCulloch v. Maryland, permitting agencies to do as they wish so long as there is a reasonable connection between their choices and congressional instructions."). This shadow effect of Chevron is, I suspect, far greater than the marginal change in case outcomes (though it is probably impossible to measure).

${ }^{50} \mathrm{In}$ fact, if you assume that the level of agency tolerance for risk is stable over time, a perhaps naive view is that Chevron shouldn't change the rate of agency victories/losses in interpretive cases at all, at least in the long term. Instead, agencies would react by increasing the aggressiveness of their interpretations until their post-Chevron success rate is the same as the pre-Chevron rate. However, this assumes that the variation in results before and after Chevron is the same. In fact, if Chevron did crystallize the law, giving more consistent results, that variation should (almost by definition) decrease. Increased certainty about outcomes should then allow agencies to be even more aggressive in their interpretations, essentially reallocating some tolerated losses from bad luck to calculated risks.

${ }^{51}$ See Sunstein, supra note 20, at 190. See also Jellum, supra note 9, at 728-29, 736-37.

${ }^{52}$ Kavanaugh, supra note 32, at 2150. 
that is, Justices have determined that although statutory ambiguity existed, the agency's interpretive resolution of that ambiguity was unreasonable (as noted above, this has been extremely rare under Chevron).

In short, Chevron has been eroded from the outside (by reducing its scope) and from the inside (by reducing the degree of deference courts give in practice, even if the doctrine does not ostensibly change or narrow). What was once a clear and simple doctrinal rule has become ever more complex over time. ${ }^{53}$ Because much of Chevron's value comes from its crystalline clarity, this increase in complexity has seriously diminished the doctrine's significance.

While a comprehensive account of the evolution of Chevron in practice is well beyond the scope of this essay, a review of the most important shifts is perhaps necessary. Chevron itself contains no obvious limiting principles - it's two-step inquiry applies whenever "a court reviews an agency's construction of the statute which it administers." ${ }^{24}$ This is Chevron-as-crystal, or as close as it gets. Courts must defer to reasonable agency interpretations of statutes. As Carol Rose's theory predicts, however, simple crystalline principles come under pressure from real-world edge cases. For Chevron, this happens fairly quickly.

\section{A. External Erosion}

Initially, the erosion was external-classes of cases were taken out of Chevron's domain because of perceived tension between deference and other values, problems of practical implementation, and other limitations. For example, Chevron deference was deemed as early as 1990 not to apply to agency interpretations of criminal statutes; interpretations of criminal statutes are reviewed de novo. ${ }^{55}$ Deference in the criminal context would conflict with the rule of lenity, and interfere with courts' longstanding central role in the administration of criminal law. ${ }^{56}$ More broadly, the danger of concentration of power in criminal adjudication is well understood-"judge, jury, and executioner." Withholding deference in the criminal context is not widely controversial; even strong defenders of

${ }^{53}$ See Dan Farber, The Chevron Doctrine: Is It Fading? Could That Help Restrain Trump?, LEGALPLANET (July 2, 2018), https://legal-planet.org/2018/07/02/straws-in-the-wind-warning-signs-for-chevron/ (detailing complexity added to Chevron over time).

${ }^{54}$ Chevron U.S.A. Inc. v. Nat. Res. Def. Council, Inc., 467 U.S. 837, 842 (1984).

55 See Crandon v. United States, 494 U.S. 152, 177 (1990) (Scalia, J., concurring) ("The Justice Department, of course, has a very specific responsibility to determine for itself what this statute means in order to decide when to prosecute; but we have never thought that the interpretation of those charged with prosecuting criminal statutes is entitled to deference."). See also United States v. Apel, 571 U.S. 359, 369 (2014) ("[W]e have never held that the Government's reading of a criminal statute is entitled to any deference.").

${ }^{56}$ See Abramski v. United States, 573 U.S. 169, 191 (2014) ("[C]riminal laws are for courts, not for the Government, to construe."). See also Kristin E. Hickman, Of Lenity, Chevron, and KPMG, 26 VA. TAX REV. 905, 916-17 (2007) ("[T]o a court thinking in lenity terms, an ambiguous statute ultimately can only have one meaning: the more lenient one."). 
deference to agencies rarely suggest it should be extended to prosecutors, ${ }^{57}$ or that carving criminal statutes out of Chevron's domain is a serious threat to the wider rule. I suspect that had someone asked Justice Stevens or the rest of the majority in Chevron, immediately after it was handed down, whether they meant it to apply to criminal statutes, they would have answered "no, of course not."

Other explicit constraints on Chevron's domain or, as Peter Strauss has called it, Chevron's space, ${ }^{58}$ have followed. An incomplete list includes interpretations articulated for the first time during litigation, ${ }^{59}$ interpretations of statutes administered by multiple agencies (including the Administrative Procedure Act itself), ${ }^{60}$ statutes for which Congress has specifically provided for de novo review, ${ }^{61}$ and interpretations regarding the scope of judicial review. ${ }^{62}$ Like the exclusion of interpretations of criminal statutes, these exceptions can be easily defended, and seem relatively modest (though the frequency of litigation and large number of cross-agency statues means both exceptions may be quite significant in practice). The Court's refusal to defer to interpretations of multi-agency statutes is an outgrowth of Chevron itself, which actually does contain a limitation on its own scope: it applies only to an agency's interpretations of statutes "which it administers." ${ }^{63}$ Multiagency statutes, by definition, aren't administered by any single agency, and therefore can't fall within Chevron's domain. The practical problems that would come from deference in this context are fairly obvious, too. Would the Court have to uphold inconsistent or even contrary interpretations of a statute by two or more agencies?

Each of these exclusions seems sensible, perhaps even obvious. ${ }^{64}$ But nevertheless, they shrink Chevron's domain, eroding the scope of its crystalline clarity. Mud creeps in.

\footnotetext{
${ }^{57}$ But see Dan M. Kahan, Is Chevron Relevant to Federal Criminal Law?, 110 HaRv. L. Rev. 469 (1996) (arguing that the common-law-like delegation of interpretive authority to courts in criminal law should instead be given to the Department of Justice).

58 Peter Strauss, "Deference" is Too Confusing-Let's Call Them "Chevron Space" and "Skidmore Weight, ” 112 COLUM. L. REV. 1143 (2012).

${ }^{59}$ See Bowen v. Georgetown Univ. Hosp., 488 U.S. 204, 212 (1988) ("We have never applied the principle of those cases to agency litigating positions that are wholly unsupported by regulations, rulings, or administrative practice.").

${ }^{60}$ See, e.g., Metro. Stevedore Co. v. Rambo, 521 U.S. 121, 138 n.9 (1997) (denying deference to an Office of Workers' Compensation Programs interpretation of the APA on the grounds that it "is not a statute that the [agency] is charged with administering").

${ }^{61}$ See 5 U.S.C. $§ 552(a)(4)(B)$ (2016) (requiring de novo review of FOIA claims). See also John C Brinkerhoff Jr \& Daniel B Listwa, Deference Conservation-FOIA's Lessons for a Chevron-less World, 71 STAN. L. REV. ONLINE 146 (2018), https://www.stanfordlawreview.org/online/deference-conservation-foias-lessons-for-achevron-less-world/.

${ }^{62}$ See Adams Fruit Co. v. Barrett, 494 U.S. 638, 650 (1990) ("[A] role for the Department of Labor in administering the statute ... does not empower the Secretary to regulate the scope of the judicial power vested by the statute.").

${ }^{63}$ Chevron U.S.A. Inc. v. Nat. Res. Def. Council, Inc., 467 U.S. 837, 842 (1984).

${ }^{64}$ Some other category exclusions are harder to explain. For example, until 2011, it was unclear whether Chevron applied in tax cases. See Mayo Found. Med. Educ. \& Rsch. v. United States, 562 U.S. 44, 54 (2011) (holding that Chevron, rather than the multifactor National Muffler standard, applied in tax cases). Mayo is a
} 
This process of external erosion of Chevron reached its peak in 2000-2001, with the Court's decisions in Christensen v. Harris County ${ }^{65}$ and, in particular, United States v. Mead Corp. ${ }^{66}$ In Mead the Court refused to defer to a Customs Service classification of imported day planners (one of 10-15,000 such interpretations each year). ${ }^{67}$ Despite the fact that such classifications are, in fact, statutory interpretations (of the tariff schedule), the Court ruled that such ministerial interpretations, lacking "the force of law", are not entitled to deference. While it's difficult to parse what the majority meant by reference to "force of law" (after all, the Customs Service determination did subject the importer to higher tariffs), the opinion does place significant emphasis on the fact that tariff categorization is a quick, nearly process-free interpretive decision by the agency. ${ }^{68}$ Christensen similarly rejected deference for agency interpretations in an opinion letter. ${ }^{69}$ The Mead majority suggests that Chevron's domain is really for agency interpretations that come out of meaningful deliberative processes, like formal adjudication and notice-and-comment rulemaking (though the Court does not go so far as to say that only interpretations in these proceedings will get deference) ${ }^{70}$

Mead's constriction of Chevron's scope can be readily defended-agencies making small-bore ministerial decisions, even when they are nominally interpretations of statutes, aren't engaging in the kind of deep technical analysis that gives them an expertise advantage over courts, and (as the court finds in Mead), Congress arguably didn't intend to delegate broad interpretive powers when it granted agencies the authority to make small decisions. ${ }^{71}$ On the other hand, it's not obvious why making large numbers of small decisions requires less expertise than big, considered and contentious rulemakings. And the effects of such decisions may be large, as the number of customs classifications indicates - the delegation of power is a big one. Turning crystal to mud in Mead is defensible, but not as obviously so as in earlier constraints on Chevron.

rare counterexample to the pattern of narrowing of Chevron's scope discussed in this section, though it may just be the Court resolving unclear precedent rather than a meaningful expansion of the doctrine.

${ }^{65} 529$ U.S. 576 (2000).

${ }^{66} 533$ U.S. 218 (2001).

${ }^{67} \mathrm{Id}$. at 233.

${ }^{68}$ Id. at 231 ("[The Customs Service's rulings] present a case far removed not only from the notice-andcomment process, but from any other circumstances reasonably suggesting that Congress ever thought of classification rulings as deserving the deference claimed for them here.").

${ }^{69} 529$ U.S. at 587.

${ }^{70}$ See Mead, 533 U.S. at 229 ("We have recognized a very good indicator of delegation meriting Chevron treatment in express congressional authorizations to engage in the process of rulemaking or adjudication that produces regulations or rulings for which deference is claimed."). But see $i d$. at 231 ("The fact that the tariff classification here was not a product of such formal process does not alone, therefore, bar the application of Chevron.").

${ }^{71} I d$. at 231 ("The authorization for classification rulings, and Customs's practice in making them, present a case far removed not only from notice-and-comment process, but from any other circumstances reasonably suggesting that Congress ever thought of classification rulings as deserving the deference claimed for them here."). 
Moreover, the Court in Mead explicitly opted for mud over crystal, reviving the moribund Skidmore deference regime, rather than opting for de novo review as in the criminal context. ${ }^{72}$ As discussed above, Skidmore grants an amorphous and highly contextsensitive degree of deference to agency interpretations. It's as muddy as standards get.

Justice Scalia objected to the Mead majority's contraction of Chevron's domain and in particular to the revival of Skidmore deference in a trademark fiery dissent. ${ }^{73}$ For Justice Scalia, Mead is "an avulsive change in judicial review of administrative action" that "has replaced the Chevron doctrine" and "we will be sorting out the consequences ... for years to come." 74 Resurrecting Skidmore "has replaced Chevron ... with that test most beloved by a court unwilling to be held to rules (and most feared by litigants who want to know what to expect): th' ol' 'totality of the circumstances' test." 75 In other words, Justice Scalia accused the Court of replacing Chevron crystal with anachronistic Skidmore mud. ${ }^{76}$ As he points out, this is doubly true: Mead introduces ambiguity both about Chevron's scope and about the degree of deference available when a case falls outside that scope. ${ }^{77} \mathrm{In}$ his view, this is pernicious. Perhaps, Scalia argues, "[i]t was possible live with the indeterminacy of Skidmore deference in earlier times[, b]ut in an era when federal statutory law administered by federal agencies is so pervasive, and when the ambiguities . . . that those statutes contain are innumerable, totality-of-the circumstances Skidmore deference is a recipe for uncertainty, unpredictably, and endless litigation." 78 Scalia closes with a prediction that Mead's "consequences will be enormous, and almost uniformly bad." 79 Nor was Scalia alone in his criticism: scholars and other commentators have called Mead and the court's attempts to apply it "incoherent" or "a mess." 80

Justice Scalia's predictions in his Mead dissent in retrospect seem somewhat overblown. He was undoubtedly correct that Mead made the deference inquiry more complex for courts and litigants, adding what Cass Sunstein has called "Step Zero" to that inquiry. ${ }^{81}$ Step Zero is a land mine students and brief writers now have to navigate, to their great frustration. Nevertheless, agencies can easily avoid Mead and retain access to Chevron deference by using APA procedures (notice-and-comment or formal adjudication). Though Mead revealed the Skidmore abyss, it can still be bridged. Even if an agency does not use

${ }^{72} I d$. at 234 ("To agree with the Court of Appeals that Customs ruling letters do not fall within Chevron is not, however, to place them outside the pale of any deference whatever. Chevron did nothing to eliminate Skidmore's holding that an agency's interpretation may merit some deference whatever its form.").

${ }^{73} \mathrm{Id}$. at 239 (Scalia, J., dissenting).

${ }^{74} \mathrm{Id}$.

${ }^{75} \mathrm{Id}$. at 241.

${ }^{76} I d$. at 250 .

${ }^{77} I d$. at 239.

${ }^{78} I d$. at 250 .

${ }^{79} \mathrm{Id}$. at 261.

${ }^{80}$ See Kristin E. Hickman, The Three Phases of Mead, 83 FordHAM L. REV. 527 (2014); see also Lisa Schultz Bressman, How Mead Has Muddled Judicial Review of Agency Action, 58 VAND. L. REV. 1443, 1444 (2005) (examining court of appeals decisions applying Mead and concluding that Justice Scalia "actually understated the effect of Mead").

${ }^{81}$ See generally Sunstein, supra note 20. 
such procedures (or lacks the authority to do so), it may still get deference, as the Court first suggested in Mead itself and has reiterated since. ${ }^{82}$ If anything, Mead clarified the issue somewhat by making the level of procedure an important marker, if not a decisive one.

Mead has also lacked the reach in practice that Scalia and other critics predicted it would have. That is due in part, however, to disagreement within the Court about the interaction between Chevron, Mead, and Skidmore. ${ }^{83}$ It is also due to further decisions that have been interpreted to substantially limit Mead's reach-most notably Barnhart $v$. Walton, decided soon after Mead. ${ }^{84}$ In an opinion by Justice Breyer, the Court in Barnhart suggested that even statutory interpretations in informal guidance documents could be entitled to Chevron deference, noting in doing so that "the interstitial nature of the legal question, the related expertise of the Agency, the importance of the question to administration of the statute, the complexity of that administration, and the careful consideration the Agency has given the question over a long period of time." ${ }^{85}$ But these factors sound much more like Skidmore's multifactor test than Chevron's ostensibly brightline rule regarding access to deference.

The edges of Chevron's scope are therefore muddy, but Mead did not make them so alone-courts had struggled for years with whether small-bore agency determinations of various types were entitled to deference. ${ }^{86}$ It often remains unclear when Mead (and therefore Chevron, Skidmore, or something in between) applies. If Mead is less important than Scalia predicted and feared, that's partly because it's even less clear when it applies than he thought. Moreover, it can be applied opportunistically, taking agency interpretations in or out of Chevron's domain as needed. ${ }^{87}$

Mead is the culmination of more than fifteen years of Supreme Court decisions restricting Chevron's scope-eroding its power from the outside. In each case, Chevron's broad (albeit never bright-line) deference rule yielded to some practical consideration. Deference to interpretations in criminal cases, of multi-agency statutes, in mere agency litigating positions, and in small-potatoes guidance documents would interfere with other important values like the rule of lenity, be unworkable in practice, or perhaps, give too much unfettered power to agencies. Or to look at it from the other side, none of these areas, one gets the sense the Court is saying, is really what Chevron was about, for good or at least defensible reasons. So is crystal ground to mud.

\footnotetext{
${ }^{82} \mathrm{Mead}, 533$ U.S. at 231 ("The fact that the tariff classification here was not a product of such formal process does not alone, therefore, bar the application of Chevron.”). See also Barnhart v. Walton, 535 U.S. 212, 221 (2002) ("the fact that the Agency previously reached its interpretation through means less formal than "notice and comment" rulemaking... does not automatically deprive that interpretation of the judicial deference otherwise its due.").

${ }^{83}$ See Hickman, supra note 80, at 530.

${ }^{84}$ Barnhart v. Walton, 535 U.S. 212 (2002).

${ }^{85} \mathrm{Id}$. at 222

${ }^{86}$ See Thomas W. Merrill \& Kristin E. Hickman, Chevron 's Domain, 89 GEO. L.J. 833 (2001).

${ }^{87}$ See, e.g., Amy J. Wildermuth, What Twombly and Mead Have in Common, 102 Nw. U. L. REv. ColloquY 276, 277-78 (2008) (claiming Mead is susceptible to "results-oriented manipulation").
} 


\section{B. Internal Erosion}

A second (albeit to some extent overlapping) phase of erosion of Chevron undercut the deference doctrine from the inside. The Court has repeatedly purported to apply Chevron while denying meaningful deference. The roots of this internal erosion may go back to Chevron's earliest days, ${ }^{88}$ but most clearly emerged in a series of cases in the early 2000 s. The doctrinal meaning of each of these cases is of course contestable, but taken together they have substantially reduced the scope of Chevron in practice. Initially, this occurred by narrowing Step One - that is, through increasing willingness to find that Congress had "clearly spoken" in a statute, thus leaving no ambiguity for an agency to interpret. More recently, at least one case suggests deference has narrowed at Step Two as well.

This sub rosa erosion of Chevron is more corrosive than external, explicit narrowing of scope because it not only reduces the doctrine's power to decide cases, but also creates ambiguity and sows doubt. At the risk of pushing the crystals and mud metaphor too far, external erosion grinds down crystalline rules, while internal erosion softens or dissolves them whole.

To be sure, the losing party, dissenting judges, and outside observers who disagree with the outcome of a case will often, perhaps always, accuse the majority of incorrectly applying relevant doctrine (or applying it in form but not in good faith). In Chevron cases, this typically comes as an accusation that the majority has found ambiguity (and therefore, under Chevron, deferred to the agency interpretation) where a harder look, applying the traditional tools of statutory interpretation, would have uncovered a clear meaning. ${ }^{89} \mathrm{Or}$, conversely, that the majority too readily found a clear meaning when deeper inquiry would have revealed ambiguity. ${ }^{90}$ The presence of such dissents and critiques is not, alone, enough to prove that Chevron is ungrounded, indeterminate, or even eroding. Disagreement over how a rule or doctrine should be applied is possible no matter how crystalline the doctrine (though one of the advantages of crystalline rules are that such disagreements are, in theory, rarer). Nevertheless, each push on the boundaries of a doctrine creates precedent for further such moves, and repeated or egregious violence done to those boundaries can render them meaningless. In my view, the Court has done such violence to the boundaries of Chevron's Step One in at least one such case, probably two, and possibly more.

The clearest case of internal erosion is FDA v. Brown \& Williamson, decided by the Court in 2000, a year before Mead. ${ }^{11}$ The Food and Drug Administration had issued

${ }^{88}$ See Jellum, supra note 9, at 748-60 (documenting evolving understandings of Step One in the 1980s and 1990s).

${ }^{89}$ See, e.g., Babbitt v. Sweet Home Chapter, Cmtys. for Great Or., 515 U.S. 687, 715 (1995) (Scalia, J., Rehnquist, J., \& Thomas, J., dissenting) (arguing that the majority failed to discern a clear textual meaning of "harm" in the Endangered Species Act).

${ }^{90}$ See, e.g., Massachusetts v. EPA, 549 U.S. 497, 558 (2007) (Roberts, C.J., Scalia, J., Thomas, J., \& Alito, J., dissenting) (" $[\mathrm{I}] \mathrm{n}$ the face of textual ambiguity, the Court's application of Chevron deference ... is nowhere to be found.").

${ }^{91}$ Food \& Drug Admin. v. Brown \& Williamson Tobacco Corp. (Brown \& Williamson), 529 U.S. 120 (2000). 
rulemakings regulating tobacco products, asserting jurisdiction based on its interpretation of its own primary governing statute, the Food, Drug, and Cosmetic Act (the FDCA). ${ }^{92}$ The FDCA gave the FDA authority to regulate "drugs" and "devices" "intended to affect the structure or any function of the body." ${ }^{93}$ In the FDA's view, nicotine was a "drug" and cigarettes were "devices" within the FDCA's definitions due to their well-established effects on the body's structure and function. ${ }^{94}$ Tobacco firms sued the agency, claiming that it lacked authority to regulate their products. ${ }^{95}$

The case comes down to a relatively simple question of statutory interpretation - are tobacco products "drugs" and/or "devices" within the FDCA's definitions? If so, the FDA has authority to (in fact, must) regulate them. If not, the agency doesn't have that authority. This is a clear-cut question of statutory interpretation that does not fall into one of the exclusions from Chevron's domain. Deference should therefore apply: unless Congress has clearly spoken (Step 1) or the agency's interpretation is unreasonable (Step 2), the agency interpretation prevails. ${ }^{96}$

Statutory interpretation is often hard. But this looks like it should be an easy case. No one seriously contests that nicotine and tobacco products affect the structure and function of the body, and are intended to do so. That's the point of smoking. Nevertheless, the Court rejected the FDA's interpretation in a 5-4 holding. ${ }^{97}$ Not only did the court reject the FDA's assertion that its interpretation reflected the plain meaning of the statute, but the Court in fact reached the opposite conclusion: Congress' clear intent in the FDCA, it ruled, was to deny the FDA regulatory authority over tobacco. ${ }^{98}$ So much for deference. Indeed, at first blush the outcome seems like anti-deference; where the statute is (or at least seems) clearly in favor of the agency's position, as it does in Brown \& Williamson no deference is necessary. Chevron didn't change that. But like I said, statutory interpretation is hard. Maybe you think the FDCA isn't as clear as I do. But even if so the agency should still prevail because, under Chevron, the Court should defer in such ambiguous cases.

The Court, of course, did not overrule Chevron in Brown \& Williamson. So what is going on? One possibility is simply motivated reasoning by the justices in the majority: uncomfortable with a major expansion in federal regulatory power, they were unwilling or unable to do what Chevron commands-to defer to agency reasonable agency interpretations of ambiguous statutes with which they personally disagree. ${ }^{99}$ Of course even if policy preferences were the driving force behind the result in Brown \& Williamson, the

${ }^{92} I d$. at $126-29$.

${ }^{93} \mathrm{Id}$.

${ }^{94} I d$. at 127.

${ }^{95} \mathrm{Id}$. at 129 .

${ }^{96}$ Chevron U.S.A. Inc. v. Nat. Res. Def. Council, Inc., 467 U.S. 837, 842-44 (1984).

${ }^{97}$ Brown \& Williamson, 529 U.S. at 161.

${ }^{98} \mathrm{Id}$. at $160-61$.

${ }^{99} \mathrm{Cf}$. Breyer, supra note 22, at 379 ("[N]either a strict view of Chevron, nor any other strictly defined verbal review formula requiring deference to an agency's interpretation of law can prove successful in the long run [because] such a formula asks judges to develop a cast of mind that often is psychologically difficult to maintain."). 
majority can't just say that in the opinion-legal reasons to reach the result have to be given. And if one is inclined to interpret the majority opinion more charitably, those reasons might be convincing. And in either case they set precedent, shaping how statutory interpretation cases under Chevron are decided afterwards.

The stated reasoning for the result in Brown \& Williamson is that extrinsic evidence, beyond the statute itself, show that Congress did not intend to grant the FDA authority to regulate tobacco (or, more precisely, interpretive authority to determine whether it had that substantive authority). ${ }^{100}$ Chevron instructs courts to divine Congressional intent via the "traditional tools of statutory interpretation": ${ }^{101}$ text, but also context, canons of interpretation, and the like. The majority in Brown \& Williamson expands the list of tools to include evidence of intent from other, later statutes. Under the FDCA, products regulated by the FDA must be "safe", but the Court concluded that "safe" tobacco was an oxymoron, and that the FDA would be forced eventually to ban cigarettes. ${ }^{102}$ This, the Court found, was inconsistent with other statutes related to tobacco passed by Congress after the FDCA, such as laws requiring warning labels or banning some tobacco advertising. ${ }^{103}$ These later statutes, under this interpretation, worked an implicit repeal of the FDCA ${ }^{104}$ (despite the fact that such implicit repeal is usually disfavored). ${ }^{105}$ The Court also pointed to the "economic and political significance" of the agency's regulatory action as a reason to conclude Congress did not intend to grant regulatory or interpretive authority (a point the Court would later clarify as an independent exception to Chevron) ${ }^{106}$ and to the inconsistency of the FDA's claim of authority with its past practice of refusing to regulate tobacco. ${ }^{107}$

The FDA, according to the majority, had misread the FDCA in its broader contextthe ostensibly clear definitions of "drug" and "device" in the statute had to be read in light of other Congressional action. Moreover, in the majority's reasoning, the tension between textual and extra-textual (indeed, statutory and extra-statutory) evidence did not just create ambiguity which, under Chevron, the agency would have had the opportunity to fill. Instead, it fully overcame the text of the statute, making the intent of Congress to deny FDA authority over tobacco unambiguous.

In simplest Chevron terms, the agency thought it didn't need deference at all, but the Court said the agency loses at Step One. It is impossible to know without probing the minds of the Justices in the majority which of these readings of Brown \& Williamson is correct (motivated reasoning or broadening of Step One to include implied repeal). I suspect some

\footnotetext{
${ }^{100}$ Brown \& Williamson, 529 U.S. at 160-61.

${ }^{101}$ Chevron, 467 U.S. at 843 n.9.

102 Brown \& Williamson, 529 U.S. at 130.

${ }^{103} \mathrm{Id}$. at 137.

${ }^{104} \mathrm{Id}$.

${ }^{105}$ See Branch v. Smith, 538 U.S. 254, 264 (2003).

${ }^{106}$ See infra discussion Section III.C.

${ }^{107}$ Brown \& Williamson, 529 U.S. at 147.
} 
of both. But for our purposes here it's not necessary to choose-both have corrosive effects on Chevron's predictability and power.

As noted above, Step One is the key to whether Chevron is crystal or mud. If Chevron had instructed courts to always and everywhere defer to agency interpretation, subsequent cases would be easy to understand and to predict. But, as noted, that would be incompatible with Marbury and probably unconstitutional. The opposite rule - de novo review of agency interpretations - would be also be crystalline with respect to the deference rule (i.e., none), but not with respect to case outcomes: the reviewing court might agree or disagree with the agency's statutory interpretation. Chevron's Step One principle-that judges defer when statutes are ambiguous - is a compromise approach. The initial meta-inquiry about ambiguity is de novo, entirely within the hands of judges. But once complete, the pendulum swings toward substantial deference. An escape hatch remains in Step Two: judges may reject "unreasonable" or "impermissible" agency interpretations, but until recently judges have rarely if ever done so. ${ }^{108}$ Therefore if Step One is broad (i.e. lots of statutes are ambiguous), Chevron deference has great power. And if the boundaries of Step One are reasonably clear (i.e. courts take a consistent approach to determining whether there's ambiguity), Chevron deference is predictable.

The Court's approach to Step One in Brown \& Williamson undercut both of these values. If one reads Brown \& Williamson as entirely results-oriented, the damage to Chevron is relatively clear. If judges have broad or unlimited freedom to decide what statutory provisions are ambiguous and which are not, according to their policy preferences and unmoored to any principle, then the deference available at Step Two should they find ambiguity is, if not meaningless, at least secondary. Substantial power would be reallocated from agencies to judges. Step One discretion would swallow Chevron.

But even if one does not read Brown \& Williamson as an exercise of naked resultsoriented judging, its expansion of the "traditional tools of statutory interpretation" has similar effects. The broader the list of factors and sources of evidence that judges may marshal to determine whether ambiguity exists, the greater their discretion and the less deferential Chevron becomes. Statutory text, context, purpose, interpretive canons, and (for some Justices) legislative history were already acknowledged as sources for divining the clarity of Congressional intent. Debate among Justices over which factors should be considered, and which should determine the outcome in any case, was of course common. ${ }^{109}$ But to the then-existing list of factors Brown $\&$ Williamson added implied repeal by subsequent statutes, the "economic and political" significance of the regulatory action, and the degree to which an agency interpretation breaks with past practice. ${ }^{110}$ In doing so, Brown \& Williamson expanded the Step One inquiry from one grounded (at least largely) in the statute toward a wide-ranging multifactor analysis, one that sounds much more like Skidmore mud than Chevron crystal. There is no way to reasonably predict which factors a

\footnotetext{
108 See BREYER ET AL., supra note 37, at 319.

${ }^{109}$ See, e.g. , Jellum, supra note 9 (describing textualist-intentionalist divide within Chevron Step One).

${ }^{110}$ Brown \& Williamson, 529 U.S. at 147.
} 
reviewing Court will choose to consider, to emphasize, and to minimize. Opportunities for results-oriented judging increase - there is little difference between a "test" with many factors and a test with none at all. Brown \& Williamson alone may not have made Chevron Step One completely indeterminate at the Court, but no other case took a bigger step in that direction.

Moreover, the Court in Brown \& Williamson announced no change in Chevron's scope, unlike with the external erosions discussed above. Brown \& Williamson was ostensibly a pure Step One case, decided within the four corners of Chevron. This has potentially greater effect on Chevron as a doctrine because the precedents it sets - the additions it makes to the Step One toolbox - are not limited to any discernible class of cases. Implied repeal, economic and political significance, and change in longstanding agency interpretation were, after Brown \& Williamson, factors that every court may (possibly must) consider in deference cases.

Justice Scalia, who would be a year later so scathing in his critique of Mead's muddying of Chevron, was in the Brown \& Williamson majority and appears to have had little or no objection to the Court's approach. This should perhaps not be surprising. as Scalia always took a broad view of the Court's toolkit for determining whether statutory language is ambiguous. In an oft-quoted defense of Chevron in 1989, he argued that:

[T] he "traditional tools of statutory construction" include not merely text and legislative history but also, quite specifically, the consideration of policy consequences.... Policy evaluation is, in other words, part of the traditional judicial tool-kit that is used in applying the first step of Chevron-the step that determines, before deferring to agency judgment, whether the law is indeed ambiguous. Only when the court concludes that the policy furthered by neither textually possible interpretation will be clearly "better" (in the sense of achieving what Congress apparently wished to achieve) will it, pursuant to Chevron, yield to the agency's choice. But the reason it yields is assuredly not that [the court] has no constitutional competence to consider and evaluate policy. ${ }^{111}$

If judges' policy preferences are a fair basis for deciding whether a statute is ambiguous, the factors added by Brown \& Williamson are small potatoes. Perhaps Scalia does not really believe judicial policy preferences should control Step One outcomes; later in the same article he praises Chevron's predictability:

Chevron is unquestionably better than what preceded it. Congress now knows that the ambiguities it creates, whether intentionally or unintentionally, will be resolved, within the bounds of permissible interpretation, not by the courts but by a particular agency, whose policy biases will ordinarily be known. ${ }^{112}$

Reconciling these two views is difficult, however. If judges' views on policy are relevant at Step One, it is unclear how Congress can rely on agency policy preferences to control

\footnotetext{
${ }^{111}$ Scalia, supra note 19 , at 515.

${ }^{112} I d$. at 517.
} 
outcomes under Chevron. "[W]ithin the bounds of permissible interpretation" in the second quotation is doing a lot of work. This indeterminacy casts Justice Scalia's Mead dissent in a new light. His version of Chevron isn't and never was the bright-line rule he claims is threatened by Mead's revival of Skidmore. Scalia's Chevron, if that is what was applied in Brown \& Williamson, shifts much less power from judges to agencies and has much less predictable outcomes than the standard account of Chevron (or his own claims) suggest. The broad view of Step One Scalia articulates in his 1989 essay seems inconsistent with the Brown \& Williamson Court's approach insofar as Scalia and the rest of the majority there include the agency's reversal of a longstanding position in the factors they consider relevant. Scalia pointed to Chevron's abandonment of that Skidmore's inclusion of agency stability of position as one of the later case's chief virtues, preventing judicial ossification of regulatory law. ${ }^{113}$

Perhaps it is unfair to single out Justice Scalia. The four other Justices in the Brown \& Williamson majority were equally willing to expand the scope of Step One. Although the four dissenting Justices argued forcefully that the Court should have deferred to the FDA's interpretation, they did not call for a narrower approach to Step One (other than by rejecting the majority's reading of later Congressional enactments). ${ }^{114}$ And many of the same Justices dissenting in Brown \& Williamson have been accused of motivated reasoning at Chevron Step One in other cases. ${ }^{115}$ My claim here is not to suggest that Justice Scalia is unique in holding a broad view of Step One that sharply limits Chevron's power and predictability; I suspect that when the chips are down it is quite difficult for any judge to do what Chevron asks and set aside their preferences in favor of the agency's. Scalia's honest inclusion of judicial policy preferences within the Step One toolkit is therefore worthy of some praise, even if it undercuts the virtues he attributes to Chevron in the same essay. It is harder to square these views and his vote in Brown \& Williamson with the rule-like Chevron he describes in his Mead dissent, however.

Brown \& Williamson was not unique in its broad view of the Court's Step One tools, nor was its influence limited to the justices who signed on to its majority opinion-a broad Step One would not be a factional project. In Massachusetts $v$. EPA decided a few years later, all four justices who would have deferred to the FDA's statutory interpretation of the FDCA refused to defer to the EPA's interpretation of the Clean Air Act that greenhouse gases that contribute to climate change were not "air pollutants" subject to regulation under the law. ${ }^{116}$ Only Justice Kennedy was in the majority in both cases. The cases differ in many important respects.

Massachusetts, like Brown \& Williamson, is marked by an aggressive approach to Step One and a resulting refusal to defer to the agency's view. Brown $\mathcal{E}$ Williamson paid little

${ }^{113} I d$.

${ }^{114}$ Brown \& Williamson, 529 U.S. at

115 See, e.g., Babbitt v. Sweet Home Chapter, Cmtys. for Great Or., 515 U.S. 687, 715 (1995) (Scalia, J., Rehnquist, J., \& Thomas, J., dissenting) (arguing that the majority failed to discern a clear textual meaning of "harm" in the Endangered Species Act based on a misreading of the statute's purpose).

${ }^{116}$ See Massachusetts v. EPA, 549 U.S. 497 (2007). 
heed to statutory text, appealing to extra-textual factors (some of them found in Step One toolbox for the first time). In contrast, the Massachusetts court focused almost solely on one textual provision of the statute, the definition of "air pollutant." 117 This required rejecting all of the agency's claims for a broader reading, including evidence from later Congressional enactments that, in the agency's view, indicated Congress did not intend to delegate authority to regulate greenhouse gases. ${ }^{118}$ This forced the majority to distinguish Brown \& Williamson, doing so with a vague pronouncement that regulatory authority over tobacco "clashed with" " "common sense' intuition" while lack of authority over greenhouse gases did not. ${ }^{119}$

Justice Scalia in dissent argued that the majority even got its textual analysis wrong, ignoring part of the relevant definition and missing ambiguity that should have gotten the agency to Step Two. ${ }^{120}$ Cass Sunstein, no critic of the administrative state in general or of climate regulation, has criticized the Massachusetts court for too quickly resolving the Step One ambiguity inquiry and (therefore) showing insufficient deference to the agency's interpretation..$^{121}$

The Court's approaches to Chevron Step One in Brown \& Williamson and Massachusetts are therefore superficially quite different-Massachusetts is all about text; Brown \& Williamson is all about, well, everything else. Such contrast probably shouldn't be surprising, given that the justices in dissent and majority are almost exactly reversed. ${ }^{122} \mathrm{But}$ a closer look is revealing - the justices' methodological approaches in the two cases are against type. Noted textualist Scalia (joined by Justice Thomas) spends a great deal of time in both cases appealing to context, purpose, and broad legislative intent. At the same time, the more liberal justices are quite willing to pound the text. This gives away the game. It is difficult to read the results in the two cases as determined by anything other than the policy preferences of a majority of the court, with mere lip service given to the statutory ambiguity inquiry in Chevron. Even if one is not willing to go that far, the extreme range of judicial flexibility in Chevron Step One still makes access to the deference in Step Two extremely unpredictable, and therefore substantially reduces Chevron's power and influence. In short, Brown \& Williamson shows that judges can dig through the Step One toolbox until they find

${ }^{117} \mathrm{Id}$. at 528 .

${ }^{118} I d$. at $529-30$.

${ }^{119} \mathrm{Id}$. at 531 .

${ }^{120} I d$. at 558 (Roberts, C.J., Scalia, J., Thomas, J., \& Alito, J., dissenting).

${ }^{121}$ See Cass R. Sunstein, Changing Climate Change, 2009-2016, 42 HARv. EnvTL. L. Rev. 231, 242-43 (2017).

${ }^{122}$ Seven of the justices on the Court when Brown \& Williamson was decided remained on the court in 2007 when Massachusetts was decided, and the two changes in personnel did not affect the Court's ideological balance. Justice Kennedy voted in the majority in both cases. Justices Breyer, Stevens, Ginsburg, and Souter dissented in Brown \& Williamson but were in the majority in Massachusetts. Justices Scalia and Thomas were in the majority in Brown \& Williamson but dissented in Massachusetts. Justices O'Connor and Rehnquist were also in the majority in Brown \& Williamson, but were replaced by Justices Alito and Roberts, who dissented in Massachusetts. 
the evidence they need, while Massachusetts shows judges can grab one tool and more or less ignore the others. If that reading is correct, almost anything is possible at Step One.

It is possible that expansion of the boundaries of Step One, eroding Chevron from the inside, was inevitable. Just as it is difficult in individual cases for judges to follow Chevron's deference command, it is difficult for courts to hold the line on a principled doctrine in the face of edge cases and other pressures; this is Carol Rose's insight. Crystal looks eternal, but cannot hold for long, much less forever. Michael Herz describes Chevron as a "selfregulatory regime" that relies "on entities [here, judges] to oversee themselves." 123 Such regimes are extremely hard to maintain. As he puts it in the Chevron context, "[o]nly in the rarest of self-protective settings will courts create and stand by a super-strong hands-off principle. Chevron has never, in practice, amounted to an abdication of the judicial role, if only because judges are not going voluntarily to disarm."124

A narrow view on the "traditional tools" available at Step One no doubt makes Chevron cases more predictable. But, as the deep disagreement over textual meaning in Massachusetts illustrates, not much. Even a small toolkit gives judges broad freedom. For example, the Court applies traditional canons of statutory construction (part of the "traditional tools") at Step One, denying deference if they allow plain meaning to be discerned. ${ }^{125}$ As Karl Llewelyn famously argued, these canons are in reality indeterminate; they do not compel a consistent reading of statutes. ${ }^{126}$ Judges may pick and choose among them to reach a preferred result. This complexity, unpredictability, and, well, muddiness gets worse as more interpretive tools are to the Step One inquiry, as the Court did in Brown $\mathcal{E}$ Williamson, shifting power back to judges. Even if one reads Brown \& Williamson as consistent with past Chevron Step One practice, all that proves is that the inquiry was always extremely broad-judges were never really, in Herz's terms, self-regulating at all.

Not all scholars read the evolution of Step One and, by extension, Chevron's power and influence the same way. Linda Jellum argues that rather than expanding in scope, Step One has narrowed; where once it looked to intent as well as text, the Court over time has come to focus almost exclusively on "a search for mere statutory clarity." 127 In Jellum's view, this narrowing explains the Court's reduced reliance on Chevron, effectively narrowing its

\footnotetext{
${ }^{123}$ Herz, supra note 10 , at 1873.

${ }^{124}$ Id. at 1871. See also Breyer, supra note 22, at 379 (noting psychological difficulty of meaningful and persistent deference doctrines).

${ }^{125}$ See, e.g., Epic Sys. Corp. v. Lewis, 138 S. Ct. 1612, 1630 (2018) ("[T]he Chevron Court explained that deference is not due unless a 'court, employing traditional tools of statutory construction,' is left with an unresolved ambiguity. ... Where, as here, the canons supply an answer, 'Chevron leaves the stage. "). But see Kenneth A. Bamberger, Normative Canons in the Review of Administrative Policymaking, 118 YALE L.J. 64 (2008) (noting tension between use of "normative" canons of construction and Chevron's allocation of interpretive authority to agencies, leading to circuit splits on how canons should be applied in Chevron cases.)

${ }^{126}$ See Karl N. Llewellyn, Remarks on the Theory of Appellate Decision and the Rules or Canons About How Statutes are to be Construed, 3 VAND. L. REV. 395 (1950).

${ }^{127}$ See Jellum, supra note 9 at 761.
} 
scope. ${ }^{128}$ Thus, Chevron has entered "senescence" because "textualism reigns." 129 As described above, I don't agree that the Court has narrowed Step One over time; quite the opposite. But Professor Jellum and I are otherwise not far apart. We agree that the Court often plays lip service to Step One ambiguity analysis in Chevron cases. For Jellum, this is evidence that Step One has become less relevant, with the Court "almost impatient" to get to deeper review at Step Two. ${ }^{130}$ Instead, I think that Step One has been expanded so much that Step Two is only very rarely relevant.

Under this view Brown \& Williamson is unusual not because of its expansive view of the tools available for determining ambiguity at Step One, but in its willingness to discuss that range openly. In other cases the Court similarly reaches its preferred result in Step One, but feels no need to discuss how in any depth. Perhaps the Brown $\mathcal{E}$ Williamson Court was forced to show the full arsenal of Step One only because the statutory language was so clearly in the agency's favor. Brown \& Williamson is emphatically not a textualist holding. In any case, Professor Jellum and I certainly agree that Chevron has declined in significance, though perhaps for somewhat different reasons.

\section{The Internal/External Distinction Blurs}

Chevron's decline has been continuous and, perhaps, inexorable. But for a time the Court was at least willing to make explicit its constraints on deference. By the late 1990s, however, implicit, internal erosion of Chevron became the norm. In my view Brown \& Williamson was the pivotal case in this trend, pulling back the curtain enough to reveal Chevron's empty core.

The best evidence that Brown \& Williamson was a major departure from previous Chevron practice is that the Court has since excised the case from the main line of Chevron jurisprudence by creating a new, explicit limitation on Chevron's scope-the so-called "major questions" doctrine. Under the doctrine, certain "extraordinary cases" involving interpretive questions that have major political, economic, or social implications are taken out of the Chevron framework. ${ }^{131}$ In other words, the major questions doctrine is, along with Mead, part of "Step Zero" of the Chevron process. ${ }^{132}$ The reference to "extraordinary cases" comes from language in Brown \& Williamson, and in later cases Brown \& Williamson and another case decided a year before, $M C I v$. $A T \mathcal{E} T$, have been treated as the first major questions doctrine cases. ${ }^{133}$ Brown $\&$ Williamson did not announce any doctrinal change, however, and in fact explicitly sited the basis for its holding within Step One (as described

\footnotetext{
${ }^{128} I d$.

${ }^{129} I d$.

${ }^{130} \mathrm{Id}$.

${ }^{131}$ See King v. Burwell, 576 U.S. 473, 485 (2015) (quoting Food \& Drug Admin. v. Brown \& Williamson Tobacco Corp., 529 U.S. 120, 159 (2000)). See also generally Nathan Richardson, Keeping Big Cases from Making Bad Law: The Resurgent “Major Questions” Doctrine, 49 ConN. L. REv. 355 (2016).

${ }^{132}$ See Sunstein, supra note 20, at 231-34.

133 See Richardson, supra note 131, at 363-67 (discussing foundational role of MCI and Brown \&
} Williamson). 
above). Neither did $M C I$ purport to change Chevron doctrine; the basis for the holding there is somewhat cryptic, but it can be read as either an Brown \& Williamson -style expansive Step One case, or a rare agency loss at Step Two. ${ }^{134}$ Despite these dubious roots, the major questions doctrine has since reappeared from time to time in subsequent Court decisions and dissents ${ }^{135}$ before being explicitly enshrined in Chevron doctrine in 2015's King v. Burwell (about which more below). ${ }^{136}$

The major questions doctrine has been heavily criticized as an erosion of Chevron and a judicial power-grab. ${ }^{137}$ As I have argued elsewhere at length, however, there is an alternative interpretation - the major questions doctrine at least cabins the erosion of Chevron in Brown \& Williamson, MCI, and their progeny to a narrow class of "major" cases. ${ }^{138}$ Without it, judges unwilling to follow Chevron's self-restraint requirements in such cases are forced to wedge their arguments into the preexisting Chevron framework, typically (as in Brown \& Williamson) by finding the statute unambiguously dictates the reading they prefer. ${ }^{139}$ Doing so muddies Step One doctrine, creating precedent for further mischief. ${ }^{140}$ A formal major questions doctrine confines that mischief to a small sandbox of cases, possibly restricted to the Supreme Court. ${ }^{141}$

Of course, that only works if the class of major cases is relatively small, and if its boundaries can be at least roughly determined in advance. ${ }^{142}$ So far the list of Supreme Court cases explicitly citing the doctrine is small, though there does seem to be a recent increase. ${ }^{143}$ But, just as with Mead's "force of law" requirement, the boundaries of the major questions doctrine have never been clear. What makes a case "major"? It appears to be some combination of economic significance, political controversy, a significant shift in the agency's asserted regulatory authority, though the cases never list factors explicitly. ${ }^{144}$ It is therefore hard to say how effective the major questions doctrine has been in constraining erosion of Chevron, much less to predict how effective it will be in the future.

The Court has also linked the major questions doctrine to a parallel quasi-clear statement rule for significant grants of regulatory authority to agencies. As Justice Scalia has repeatedly articulated the principle, "Congress does not hide elephants in mouseholes" - in other words, courts will be unwilling to resolve statutory ambiguities in

${ }^{134} I d$. at $364-65$.

${ }^{135} \mathrm{Id}$. at $360-78$.

${ }^{136}$ See King v. Burwell, 576 U.S. 473, 485 (2015). length).

137 See Richardson, supra note 131, at 390-409 (discussing critiques of the major questions doctrine at

${ }^{138}$ See generally id.

${ }^{139} \mathrm{Id}$. at $409-29$.

${ }^{140} I d$.

${ }^{141} I d$.

${ }^{142} I d$. at 426.

${ }^{143} I d$. at $376-79$.

${ }^{144} I d$. at $381-85$. 
favor of agencies if doing so would substantially increase their authority. ${ }^{145}$ It is unclear where in the Chevron framework this principle does its work. Some of the cases suggest it is an additional factor in the major questions doctrine analysis - where statutory support is in some sense thin, and the implications large, Chevron will not apply at all. ${ }^{146}$ Or the principle may operate within Step One, setting a higher bar for ambiguity where the agency's resolution of the claimed ambiguity would substantially increase its authority. ${ }^{147}$ Either interpretation reduces Chevron's power and predictability, however. "Elephants in mouseholes" is a simple principle in application-it increases the degree of statutory ambiguity required for agencies to access Chevron deference.

Making sense of the effect of these doctrines and principles on Chevron is difficult, but the apparent effect is to create two additional hurdles for agencies seeking deference. Step One requires there to be some statutory ambiguity. But if the agency's interpretation of that alleged ambiguity substantially increases agency authority, deference may still not be available under the "elephants in mouseholes" doctrine. Instead a clear statement from Congress -i.e., lack of ambiguity - is required. And even statutory text strongly in favor of the agency's reading can be overcome if the economic and/or political significance is sufficient to make it an "extraordinary case," which the major questions doctrine takes out of the Chevron framework entirely. It is, of course, courts who decide when and whether these three hurdles have been overcome. All have unclear margins but lie in wait to disarm Chevron whenever called upon.

\section{Empirical Analysis of Chevron}

By the mid-2000s, Chevron was "mature," with over two decades of refinement of its analytic process and definition of its scope. As the preceding discussion illustrates, that evolution had been inexorably in the direction of a narrower, weaker Chevron, but nevertheless it had become generally understood as the defining case on agency interpretations of statutes. Justice Scalia's dissent in Mead, excoriating the majority for unearthing an ancient and discarded Skidmore deference, ${ }^{148}$ is perhaps the best evidence of Chevron's official supremacy.

How powerful and predictive (i.e. how crystalline) was Chevron at that point? In 2008, William Eskridge and Lauren Baer published a comprehensive and highly influential

145 See Whitman v. Am. Trucking Ass'ns, 531 U.S. 457, 468 (2001) ("Congress, we have held, does not alter the fundamental details of a regulatory scheme in vague terms or ancillary provisions - it does not, one might say, hide elephants in mouseholes."). See also Utility Air Regulatory Grp. v. EPA, 573 U.S. 302, 324 (2014) ("We expect Congress to speak clearly if it wishes to assign to an agency decisions of vast "economic and political significance." " (quoting Food \& Drug Admin. v. Brown \& Williamson Tobacco Corp., 529 U.S. 120, 160 (2000)).

${ }^{146}$ See Richardson, supra note 131 , at 371-76.

${ }^{147} I d$.

${ }^{148}$ United States v. Mead Corp., 533 U.S. 218, 239 (2001) (Scalia, J., dissenting). 
analysis of agency statutory interpretation cases at the Supreme Court. ${ }^{149}$ Their dataset included roughly 1000 post-Chevron cases decided between 1984 and 2006 (so including MCI and Brown \& Williamson, but not Massachusetts). ${ }^{150}$ On the one hand, they found that the Court rarely applied Chevron, doing so in only $28.5 \%$ of the cases they identify as within Chevron's scope, as defined by Mead. ${ }^{151}$ This led Eskridge and Baer to conclude that "[b]ased upon our data, we conclude that there has not been a Chevron 'revolution' at the Supreme Court level." 152 When applied, however, Chevron did appear to meaningfully increase agencies' rate of success (76.2\% under Chevron, relative to $68.3 \%$ in all cases). ${ }^{153}$ Another empirical study by Cass Sunstein and Thomas Miles found a slightly lower agency success rate of $67 \%$ over cases between 1989 and 2006. ${ }^{154}$ The differences between the two studies' findings may be due to methodological differences, or they may indicate that the Court became less deferential in Chevron cases after $1990 .{ }^{155}$ Overall, these two analyses support the view that Chevron was powerful, affecting case outcomes, and possibly increasing the predictability of those outcomes (though perhaps not by as much as its reputation would suggest)..$^{156}$

More recent scholarship has cast some doubt on elements of Eskridge and Baer's analysis. 2018 research by Natalie Salmanowitz and Holger Spamann, relying on parties' briefs in a subset of the same cases analyzed by Eskridge \& Baer, found that the Court actually applied Chevron in a much greater percentage of applicable cases, around $80 \%{ }^{157}$ If this revised estimate is correct, then Chevron looks even more far-reaching (at least through 2006).

However, both the Salmanowitz/Spamann $80 \%$ and Eskridge/Baer 28.5\% estimates are somewhat misleading in this regard, as they constrain the denominator to Chevron as circumscribed by Mead -in other words they take some or all of the doctrinal erosion of Chevron for granted in defining its ambit. ${ }^{158}$ Eskridge and Baer's $8.4 \%$ estimate (the number of cases applying Chevron relative to their entire dataset of agency statutory interpretation cases) is the only figure that does not do this. ${ }^{159}$ As of 2006, therefore, the case for Chevron's power and influence at the Court was mixed. The trend since has been clearer.

${ }^{149}$ Eskridge \& Baer, supra note 48. See also Natalie Salmanowitz \& Holger Spamann, Does the Supreme Court Really Not Apply Chevron When It Should?, 57 INT'L REv. L. \& ECON. 81, 81 (2019) (characterizing Eskridge \& Baer's article as "one of the most highly cited legal empirical articles ever published").

${ }^{150}$ Eskridge \& Baer, supra note 48, at 1094.

${ }^{151} I d$. at 1125.

${ }^{152} \mathrm{Id}$. at 1090 .

${ }^{153} I d$. at $1099-1100$.

${ }^{154}$ See Thomas J. Miles \& Cass R. Sunstein, Do Judges Make Regulatory Policy? An Empirical Investigation of Chevron, 73 U. CHI. L. REV. 823, 849 (2006).

155 See Richard J. Pierce, Jr., What Do the Studies of Judicial Review of Agency Actions Mean?, 63 ADMIN. L. REV., no. 1, 2011, at 77, 83.

${ }^{156}$ But see id. at 85 (concluding from these two and other empirical studies that the choice of deference doctrines does not matter much for case outcomes).

${ }^{157}$ See Salmanowitz \& Spamann, supra note 149, at 89.

${ }^{158} I d$. at 82.

${ }^{159}$ Eskridge \& Baer, supra note 48, at 1125. 


\section{CHEVRONTODAY}

\section{A. The Foundations Crumble (2013-2015)}

Chevron's decline did not stop in 2006, however; in fact it has accelerated in recent years. Four cases from 2013-2015 are particularly important: City of Arlington v. FCC, ${ }^{160}$ Utility Air Regulatory Group v. EPA, ${ }^{161}$ King v. Burwell, ${ }^{162}$ and Michigan v. EPA. ${ }^{163}$ They are explored below, followed by an overview of cases in the last four Court terms, during which Chevron has only once determined a case's outcome.

\section{City of Arlington, Texas v. FCC}

City of Arlington, Texas v. FCC, decided in 2013, is noteworthy as a near-miss erosion of Chevron's power and predictability. In the case, the Court considered whether "jurisdictional" agency statutory interpretations were entitled to Chevron deference. ${ }^{164} \mathrm{In}$ a 6-3 opinion authored by Justice Scalia, the Court said no, ${ }^{165}$ over dissent from Chief Justice Roberts. ${ }^{166}$ This was not because agency control over the boundaries of their own authority was not troubling to Scalia-foxes guarding henhouses is the prevailing metaphor. ${ }^{167}$ But instead he and the other justices in the majority rejected a jurisdictional limitation on Chevron because it would be impossible to administer in practice. ${ }^{168}$ In Scalia's view, it is impossible to draw a line between jurisdictional and non-jurisdictional questions. ${ }^{169}$ Interpreting regulatory statutes always (or almost always) means deciding whether some class of behavior comes within the regulatory ambit of an agency. ${ }^{170}$ In other words, everything is jurisdictional. "The effect would be to transfer any number of interpretive decisions... from the agencies that administer the statutes to federal courts." 171

As Professor Herz has observed, "[f]or Justice Scalia, this was a case about whether Chevron lived or died... on this account, City of Arlington is the case that saved Chevron." 172 Carve out jurisdictional questions, and Chevron loses its heart, or at least its power to affect outcomes by allocating interpretive authority. ${ }^{173}$ But had City of Arlington

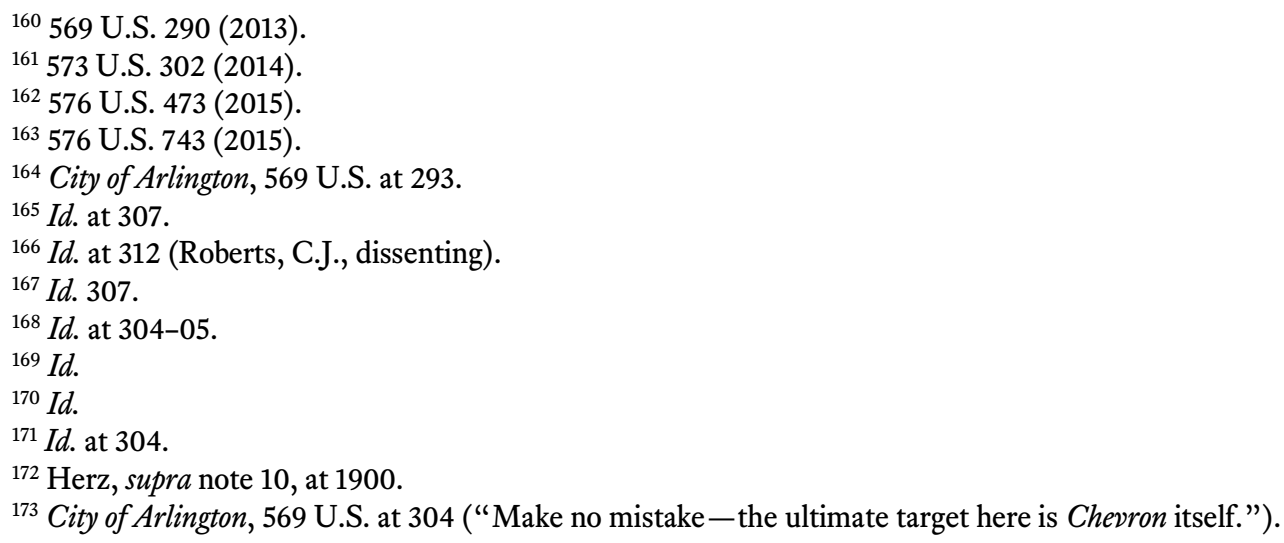


come out the other way it would have added another explicit exception to Chevron to the already-long list. What makes a jurisdictional exclusion fatal to Chevron but not the other exclusions and erosions? Perhaps it's too big an exclusion, or too malleable; this seems to be Scalia's view. ${ }^{174}$ Maybe that's right, but some of the already-established limitations on Chevron's scope seem either larger, fuzzier, or both (most notably the major questions doctrine). And the steady growth in court's tool kit and power in Step One has similar effects to those Scalia fears from a jurisdictional exclusion. Courts (and litigants) can pick and choose arguments, and the effect is to "transfer any number of interpretive decisions" from agencies to the courts. What Scalia feared in City of Arlington had already come to pass, years before (as he warned in Mead, or was happy to permit in Brown \& Williamson).

Even the rejection of a jurisdictional exclusion in City of Arlington may not matter much in the long run. Herz compares Justice Scalia's opinion and Chief Justice Roberts' dissent to ships passing in the night, having much in common. ${ }^{175} \mathrm{He}$ further argues that courts applying the case do in practice exclude some "jurisdictional" component of the interpretive inquiry from Chevron deference, making it effectively part of "Step Zero."176 If this view is correct, City of Arlington was not so much a failed attempt to constrain Chevron as it was a failed attempt to elevate a common practice into established doctrine. The damage Herz argues this would do to Chevron was already happening. If Scalia "saved" Chevron it was by keeping its erosion from becoming obvious.

Even if one does view City of Arlington as a near miss, its rejection of a further categorical exclusion did not augur a turn in Chevron's fortunes, or even much of a pause in its decline. Assault continued over the next two Court terms.

\section{Utility Air Regulatory Group (UARG) v. EPA}

The first illustration came in $U A R G v . E P A$, decided in the next term. ${ }^{177}$ It concerned interpretation of a Clean Air Act provision setting emissions thresholds above which a review and permitting process is required. ${ }^{178}$ If rigidly applied, a large number of very small emissions sources would become subject to EPA regulation - something neither they nor, crucially, the EPA itself wanted. ${ }^{179}$ EPA argued that the numerical thresholds in the statute were an unambiguous directive that it could only avoid because applying them would lead to "absurd results." 180 In a 9-0 decision, the Court agreed that the statute was unambiguous, but in the opposite direction; Congress could not have intended for the thresholds to apply to all pollutants, based on a searching review of similar terms used

${ }^{174} I d$. at 304-05.

${ }^{175}$ Herz, supra note 10, at 1905.

${ }^{176} I d$. at $1905-06$.

177 Utility Air Regulatory Group (UARG) v. EPA, 573 U.S. 302 (2014).

${ }^{178} I d$. at 308-09.

${ }^{179} \mathrm{Id}$. at 312 .

${ }^{180}$ See Prevention of Significant Deterioration and Title V Greenhouse Gas Tailoring Rule; Final Rule, 75 Fed. Reg. 31514, 31516 (June 3, 2010) (to be codified at 40 C.F.R. pts. 50, 51, 70, 71) (defending refusal to apply PSD regulations to small sources as "administrative necessity" that avoids "absurd results"). 
throughout the statute. ${ }^{181}$ In this case, at least, the ambiguity question (Step One) swallowed the range of deference entirely. ${ }^{182}$ Not just the outcome, but the arguments in the case would have been no different if it were decided under Skidmore's multifactor standard. $U A R G$ was a debate in the briefs and opinion about the best reading of a statutory provision that, if strictly applied, would lead to costly and probably unintended results. The Court listened to the agency's reading but unwilling to cede any real interpretive authority.

$U A R G$ is an excellent illustration of how little middle ground is left in Chevron cases in which deference might operate. The agency said the statute meant $X$. The Court said it unambiguously meant Y. UARG is not unique. The scope of Step One has been expanding, at least since Brown \& Williamson. It is now common for both sides of an interpretive dispute to claim that their reading of the statute is the only correct or plausible reading (and that therefore they should win at Chevron's Step One) ${ }^{183}$ The ubiquity of claims of clarity means that cases are really decided at Step One, before Chevron's deference is available at all.

Sometimes statutes are clear, of course, but when crystals become mud, the devil can cite scripture for his purpose. Big, complex statutes like the Clean Air Act, under which many interpretive cases are decided, seem particularly vulnerable: it's usually possible to find something in the statute, somewhere, that supports a given reading, then selectively cite evidence to support a claim that the reading is clear. The contrast with Massachusetts is telling: both cases interpreted similar language ("any air pollutant") in the same statute, yet concluded that language clearly had different meanings. If it is possible to do that without admitting that the language is ambiguous, then the door to deference at Step Two is effectively closed. Internal erosion of Chevron is complete.

\section{King v. Burwell}

External erosion of Chevron continued as well. The Court considered a particularly high-profile case of agency statutory interpretation in 2015 in King v. Burwell. ${ }^{184}$ Litigants challenged the federal government's implementation of health insurance markets, claiming the Affordable Care Act only authorized subsidies to those buying insurance on state-run exchanges. ${ }^{185}$ The IRS interpreted the statute to allow subsidies for users of both federal

\footnotetext{
${ }^{181}$ Utility Air Regulatory Group v. EPA, 573 U.S. at 315-20.

${ }^{182}$ Id. EPA therefore "lost" the case in the formal sense, but because it had not really wanted to regulate most of the emissions sources in question anyway, it ended up with more or less the policy result/regulatory authority it wanted. EPA's entire litigation position was, more or less, "stop me before I regulate again."

${ }^{183}$ It is perhaps unsurprising that parties would so claim; they and their advocates are likely to see their preferred result as the only plausible reading of a statute. But it is more surprising when Justices do the same. UARG and Massachusetts are one example, but it sometimes happens in the same case. See, e.g., County of Maui, Haw. v. Haw. Wildlife Fund, 140 S. Ct. 1462 (2020) (demonstrating that both Justice Breyer's majority opinion and Justice Alito's dissent would resolve the interpretive question at Step One, but with opposite results).

${ }^{184} 576$ U.S. 473 (2015).

${ }^{185} \mathrm{Id}$. at $482-85$.
} 
and state exchanges. ${ }^{186}$ This seemingly technical matter had major implications; if subsidies were made unavailable to citizens in the group of states refusing to run their own exchanges, a significant part of the Obamacare health insurance market could collapse. ${ }^{187}$ Obamacare's high political profile added to the case's salience.

Nevertheless, the case was a very straightforward matter of statutory interpretation. Should the text of the statute, authorizing subsidies for users of exchanges "established by the State", be construed narrowly, or should other evidence of Congressional intent (context, history, other enactments or lack thereof, etc.) be interpreted to allow subsidies for users of federal exchanges? The relevant agency adopted the latter, broader reading. Although (in a 6-3 opinion by Chief Justice Roberts) the Court agreed, upholding the legality of the subsidies, ${ }^{188}$ it explicitly afforded no deference to the agency's position. ${ }^{189}$ Chevron would seem to have required deference, at least unless the meaning of the statute was clear; in its decision below the 4th Circuit applied Chevron and deferred to the IRS' interpretation. ${ }^{190}$

One option available to the Court was of course to find that the text of the statute foreclosed the IRS' interpretation, thereby denying deference at Chevron Step One; Justice Scalia's dissent would have done so. ${ }^{191}$ Another option would have been to rule that Congress unambiguously intended the subsidies to be available to users of federal exchanges; i.e. that the statute was clear in the other direction. If so, then Chevron deference would be irrelevant. Of course such a reading of the statute would be in a great deal of tension with the text of the relevant provision, making it difficult to conclude with a straight face that the statute is not ambiguous. On the other hand that didn't stop the Court in Brown \& Williamson.

Instead, Chief Justice Roberts rejected both of these options and admitted that the statute was ambiguous, considering text, context, purpose, and other factors. ${ }^{192}$ Having concluded that Congress had not "clearly spoken", under the traditional Chevron framework, the Court should have deferred to the agency. But under the modern, constrained Chevron, Roberts concluded that no deference was available, for three reasons - two previously announced, and one new. First, Roberts applied the "elephants in mouseholes" clear statement rule, citing UARG (itself citing Brown \& Williamson):

The tax credits are among the Act's key reforms, involving billions of dollars in spending each year and affecting the price of health insurance for millions of people. Whether those

${ }^{186} I d$. at $482-83$.

${ }^{187} \mathrm{Id}$. at $492-94$.

${ }^{188} I d$.

${ }^{189} \mathrm{Id}$. at $484-505$.

${ }^{190} I d$. at $484-85$.

${ }^{191} I d$. at 499 (Scalia, J., Thomas, J., and Alito, J., dissenting) ("You would think the answer would be obvious - so obvious there would hardly be a need for the Supreme Court to hear a case about it."). See also id. at 510 (Scalia, J., Thomas, J., and Alito, J., dissenting) ("If that is all it takes to make something ambiguous, everything is ambiguous.").

${ }^{192} I d$. at $485-92$. 
credits are available on Federal Exchanges is thus a question of deep "economic and political significance" that is central to this statutory scheme; had Congress wished to assign that question to an agency, it surely would have done so expressly. ${ }^{193}$

Second, the opinion classed the case as "extraordinary", again citing Brown \& Williamson, explicitly applying the major questions doctrine to take the case out of Chevron's domain. ${ }^{194}$

While not new, both of these doctrines limiting Chevron were given their clearest endorsement to date in King v. Burwell. Some had argued the major questions doctrine was dormant or even dead before King was decided. ${ }^{195}$ Moreover, recall that Brown \& Williamson did not explicitly create a new doctrine; it was ostensibly a Step One case. ${ }^{196}$ Unless one views the "elephants in mouseholes" doctrine as indistinguishable from the major questions doctrine, ${ }^{197}$ King was the first Supreme Court case to explicitly state that "extraordinary cases" were outside Chevron's domain. Law professors had debated the major questions doctrine at length, ${ }^{198}$ but it had yet to be formally acknowledged by the Court. Therefore even without announcing new doctrine, King reduced Chevron's reach by solidifying-dare I say, crystallizing - constraints the Court had already put on deference.

At the same time, King was a missed opportunity to add some clarity to the major questions doctrine. The actual interpretive question at issue in the case was relatively minor, in that it involved a single, short sentence appearing once in the statute ( $U A R G$ was far more complex in this regard) and no broad expansion of IRS authority. ${ }^{199}$ But of course its implications were great; as the opinion discusses, without tax subsidies the federal exchanges might fail, and a substantial portion of the policy changes wrought by the ACA with them. ${ }^{200}$ This suggests that the ultimate effects of a statutory interpretation move are what makes a question "major", however incremental that interpretive move is on its own terms. This is in some tension with Brown \& Williamson and the "elephants in mouseholes" principle, which seem to be driven by the size of the agency's claimed increase in authority (e.g., the FDA's claim of authority to regulate tobacco in Brown \& Williamson or the EPA's claim of authority over small GHG emitters in $U A R G$ ). How much does context matter for determining whether a question is major? How big of a role does political controversy play? Was King a major questions case because it made headlines? Given its high political profile

${ }^{193} I d$. at $485-87$.

${ }^{194} I d$. at 484-85.

${ }^{195}$ See, e.g., Abigail R. Moncrieff, Reincarnating the "Major Questions" Exception to Chevron Deference as a Doctrine of Noninterference (or why Massachusetts v. EPA Got it Wrong), 60 ADMIN. L. REv. 593, 594 (2008) ("In Massachusetts v. EPA . . the Court dealt a fatal blow to a fledgling, though controversial, doctrine: the "major questions' exception to Chevron deference.").

${ }^{196}$ See supra discussion Section III.B.

197 See Richardson, supra note 131, at 371-76.

${ }^{198}$ See, e.g., Moncrieff, supra note 195. See also Sunstein, supra note 20.

199 Of course, the ACA itself was a broad regulatory expansion, and to the extent a small IRS role in subsidies held up the entire statute, that expansion was at issue in the case, albeit indirectly.

${ }^{200}$ King v. Burwell, 576 U.S. 473, 492-94 (2015). 
and the economic significance of the healthcare industry, perhaps King was a clear major questions case. Or perhaps it just barely crossed the major questions bar. The Court did not say.

The third and final reason Roberts refused to defer was on the grounds that the IRS lacked the relevant expertise: "[i]t is especially unlikely that Congress would have delegated this decision to the IRS, which has no expertise in crafting health insurance policy of this sort", he concluded. ${ }^{201}$ This deference-denying rationale was new; the Court had not to my knowledge previously denied deference based on an assessment of the agency's expertise. Roberts cited a 2006 case, Gonzales v. Oregon, ${ }^{202}$ but that case is at most a weak precedent. To the extent Gonzales relied on the level of agency expertise it was to determine which agency should receive deference in the context of a statute that bifurcates authority among multiple agencies, not whether an agency or the Court should decide an interpretive question. ${ }^{203}$

This new "stay in your lane" limitation on Chevron creates another hurdle agencies must cross before deference will be made available: they must convince the court that they have the technical chops in the relevant area. This could easily become a requirement little different from Skidmore's "power to persuade" factor-indeed Gonzales specifically cites this Skidmore requirement after denying deference. ${ }^{204}$

Returning to King v. Burwell, Chief Justice Roberts' conclusion that the IRS lacks the relevant expertise is not at all convincing, and illustrates the degree to which the "stay in your lane" doctrinal addition further constrains Chevron. Roberts insinuates that the IRS has drifted away from its area of expertise (tax) into an area (health care) where its views carry no weight.$^{205}$ It's true that the tax subsidies in question are part of health care policy, but they are still tax subsidies. The IRS may or may not know much about how to craft health care policy (e.g. how to set up the exchanges), but it does have expertise on taxes. Given how much of US federal policy is implemented through the tax code, denying deference to the IRS whenever a tax measure has implications beyond revenue, as King $v$. Burwell appears to do, effects a major reduction in Chevron's scope. Congress has not carefully restricted authority it delegates to agencies to narrow lanes of expertise.

\footnotetext{
${ }^{201} I d$. at 474.

202546 U.S. 243 (2006).

${ }^{203} I d$. at 265-70. The statute at issue in Gonzales divided authority for determining whether drugs may be sold among the Secretary of Health and Human Services and the Attorney General, with (broadly speaking) the former charged with resolving medical and scientific questions, and the latter with legal ones. Because the case concerned an "interpretive rule" issued unilaterally by the Attorney General, the Court concluded that whether the interpretation at issue was medical or legal was relevant-if it was medical, not legal, the Attorney General lacked the authority to issue it. Expertise is of course relevant in that inquiry, but the inquiry is important only because of the bifurcated structure of the statute. The ACA also allocated authority to multiple agencies, but the specific authority at issue in King, that of tax subsidies for users of exchanges, was exclusively delegated to the IRS.

${ }^{204} I d$. at 268-69.

${ }^{205}$ King v. Burwell, 576 U.S. 473, 485-87 (2015).
} 
Also, the "stay in your lane" exception appears to be separate from the preexisting exclusion from Chevron of statutes administered by multiple agencies. The Court in King (or in Gonzales) could have easily applied this exclusion to deny deference, but neither court did so, nor did either explain why. In both cases Congress bifurcated authority between multiple agencies for good reason; in the ACA, it makes a lot of sense to delegate health policy decisions to HHS and implementation of tax changes to the IRS. Modern, complex statutes frequently divide authority in similar ways, or different statutes may compel agencies to regulate in overlapping areas. ${ }^{206}$ This undercuts the Court's assertion that the IRS lacked relevant expertise. Even if the "multiple agencies" exception is withering, or only applies to truly general statutes like the Administrative Procedure Act, then the newly articulated "stay in your lane" expertise exclusion is an even more powerful replacement.

King is important not only as an illustration of modern application of Chevron's myriad exceptions, but in that it substantially strengthens those exceptions. In applying both the "major questions" and "stay in your lane"/expertise exceptions, the King majority unearths principles from earlier cases (Brown \& Williamson and Gonzales, respectively) that were not decisive in those cases, and crystallizes them into rules readily applicable in future cases. It is entirely possible that, without $K i n g$, the major questions doctrine would have withered away, or at most remained a dormant curiosity, cited and discussed by far more law review articles than cases. Now, any agency litigating at the Supreme Court must consider whether it will be denied deference because the case is too important. ${ }^{207}$ In this way, King bootstraps Brown \& Williamson and Gonzales, shielding it from accusations that it is creating new rules and elevating dicta to doctrine in the process.

\section{Michigan v. EPA}

In Michigan v. EPA, decided only a few days after King, the Court again rejected an agency's statutory interpretation. ${ }^{208}$ However, unlike in King, the Court granted deference but still rejected the agency's interpretation as unreasonable, despite that deference. ${ }^{209} \mathrm{In}$ other words, the EPA suffered the ignominy of an almost unheard-of loss at Chevron Step Two. The case involved a detailed Clean Air Act issue that is too complex to describe in depth here. But the short version is that the EPA was required to evaluate whether regulating certain emissions from coal power plants was "appropriate and necessary." 210

206 See, e.g., Light-Duty Vehicle Greenhouse Gas Emission Standards and Corporate Average Fuel Economy Standards; Final Rule, 75 Fed. Reg. 25324 (May 7, 2010) (to be codified at 40 C.F.R. pts. 85, 86, 600; 49 C.F.R. pts. 531, 533, 536-538) (joint rulemaking between EPA and NHTSA, part of the Department of Transportation, setting federal fuel economy and emissions standards).

${ }^{207}$ See Richardson, supra note 131, at 424-25 (discussing implications of the major questions doctrine for the Clean Power Plan, an Obama-era attempt to regulate greenhouse gas emissions from power plants).

208576 U.S. 743 (2015).

${ }^{209} I d$. at 759 (characterizing EPA's reading of the statute as "unreasonable").

${ }^{210} \mathrm{Id}$. at 747. 
The agency did so, but without reference to cost, interpreting "appropriate and necessary" to require evaluation only of environmental and technical criteria. ${ }^{211}$

The Court, in an opinion by Justice Scalia, rejected this reading of the statute. ${ }^{212}$ Scalia admitted that the "appropriate and necessary" language was ambiguous in that it did not clearly direct EPA to consider cost, ${ }^{213}$ but ruled that interpreting as EPA did, ignoring cost entirely at this threshold stage, was beyond "the bounds of reasonable interpretation." 214 This was not because, in the majority's view, the EPA's interpretation was incompatible with the text-as Scalia concedes, "[t]here are undoubtedly settings in which the phrase "appropriate and necessary" does not encompass cost." ${ }^{215}$ Nevertheless, context dictated a reading that the text alone did not; as the Court held, "[r]ead naturally in the present context, the phrase 'appropriate and necessary' requires at least some attention to cost." 216

One possible interpretation of Michigan is that it signals further erosion of Chevron deference. It could signal increased willingness at the Court to overrule agency interpretations of admittedly ambiguous provisions. If such Step Two losses for agencies were to become common, then it would become clear that Chevron's core is empty. Previous erosions have limited access to deference by explicitly restricting Chevron's scope, or by implicitly expanding judges' ability to deny deference at Step One. Expanding Step Two would cut to Chevron's heart-Step Two is where the deference magic happens. Past expansion of grounds for denying deference at Step One provides a ready model for erosion of Step Two-scattered case outcomes may gradually crystallize into categories of interpretations that the court deems presumptively or per se unreasonable.

It is possible that in retrospect Michigan will be the first step along this path. It is, in my view, a strong assertion of broad judicial authority at Chevron Step Two. Or, in other words, I don't view the agency's interpretation as particularly unusual, much less unreasonable. As the dissent in Michigan puts it:

Judges may interfere only if the Agency's way of ordering its regulatory process is unreasonable-i.e., something Congress would never have allowed. The question here, as in our seminal case directing courts to defer to agency interpretations of their own statutes [Chevron], arises "not in a sterile textual vacuum, but in the context of implementing policy decisions in a technical and complex arena." ... EPA's experience and expertise. .. and courts' lack of those attributes-demand that judicial review proceed with caution and care. The majority actually phrases this principle well, though honors it only in the breach: Within wide bounds, it is "up to the Agency to decide ... how to account for cost." That judges might have made different regulatory choices-might have considered costs in different ways at different times-will not suffice to overturn EPA's action where

\footnotetext{
${ }^{211} \mathrm{Id}$. at $748-50$.

${ }^{212} \mathrm{Id}$. at 760.

${ }^{213} I d$. at 752 ("[T] his term leaves agencies with flexibility.").

${ }^{214} \mathrm{Id}$.

${ }^{215} \mathrm{Id}$.

${ }^{216} I d$.
} 
Congress, as here, chose not to speak directly to those matters, but to leave them to the Agency to decide. ${ }^{217}$

If the majority were to have announced a general rule that agency interpretations of ambiguous provisions so as not to require consideration of costs are presumptively unreasonable, it would be a substantial constraint on Chevron deference. Not announcing such a rule but implying that similar interpretations will not receive deference does even more damage to Chevron's predictability for agencies.

But reasonable people may disagree about whether an interpretation is reasonable, and disagreement about whether Chevron dictates a particular case's outcome is not good evidence, alone, that deference is being weakened. The Court in Michigan announces no new doctrinal rule, merely an application of Step Two's reasonableness constraint, something present since Chevron was decided. Judges have always had the right to reject at least some agency interpretations of ambiguous statutes. Chevron is, after all, a deference doctrine, not an abdication doctrine. Michigan is unusual because the power to reject agency interpretations at Step Two has been used so rarely, not because that power is new.

Refusal to defer at Step Two may not even, in reality, be quite so unusual. A common view, perhaps the consensus view, among academics is that Step Two is indistinguishable from State Farm-style arbitrary and capricious review under the APA. ${ }^{218}$ This, too, is a deferential standard, but agencies do lose these cases from time to time. ${ }^{219}$ So perhaps Michigan is not so radical. Time will tell whether it is an outlier or the harbinger of erosion of deference at Step Two. At a minimum it is a shot across the bow of agencies.

At the same time, Justice Thomas thought Justice Scalia's opinion didn't go far enough. In concurrence, he explicitly called for Chevron to be reconsidered, on separation of powers grounds. ${ }^{220}$ This would become a recurring pattern for Justice Thomas in Chevron cases over the next few years.

\section{B. The Death of Deference (2016-2020)}

Michigan, UARG, and City of Arlington are not unique. In the years since they were decided, the Court has continued to show little or no appetite for meaningful deference to agencies. At the same time, open criticism of Chevron has risen to the surface. The result has been a total collapse in deference to agency statutory interpretations at the Supreme Court level. Three patterns in Chevron's treatment at the Court over this period (the 201516 through 2019-20 terms) illustrate the decline in deference.

First, the Court cites Chevron much less than it used to. This decline appears to be a long-term trend. Thomas Merrill found in 1992 that the Court cited Chevron in ten to

${ }^{217} I d$. at 771 (Kagan, J., Ginsburg, J., Breyer, J., \& Sotomayor, J., dissenting) (cleaned up).

${ }^{218}$ See Stephenson \& Vermeule, supra note 36.

${ }^{219}$ See VERMEULE, supra note 13, at 158 (finding a 92\% win rate for agencies in arbitrariness challenges at the Supreme Court).

${ }^{220}$ Michigan v. EPA, 576 U.S. 743, 760-64 (2015) (Thomas, J., concurring). 
twenty statutory interpretation cases per year. ${ }^{221}$ Linda Jellum found that by 2006 this had declined precipitously; she identified four citations to Chevron in majority opinions in the 2005-2006 term, only one in the 2004-2005 term, and five in the 2003-2004 term. ${ }^{22}$ This rate of around three per term in the 2000s remains about the same today-Chevron was cited in majority opinions 15 times since the 2015-2016 term, an average of exactly three times per term (and never more than five times). ${ }^{223}$ To some extent this decline is surely due to a parallel decline in the number of cases the Court decides, something Jellum notes in 2006 as well. ${ }^{224}$ In fact the continuing decline in Court opinions at the Court since $2006^{225}$ without a corresponding decline in Chevron citations could be taken to suggest it has risen slightly in significance since then, though with just a few citations per year such small differences are unlikely to mean much.

Second, the decline in citations to Chevron should not be taken to indicate a simple decline in the number of agency statutory interpretation cases. In recent cases the Court has sometimes failed to mention Chevron at all, despite an agency interpretation of a statute being at issue. ${ }^{226}$ The number of such cases is hard to determine precisely, and whether it has declined depends on what one takes to be the best measure of the past rate (whether the $26.8 \%$ found by Eskridge \& Baer, or the roughly $80 \%$ found by Salmanowitz and Spamann). ${ }^{227}$ Scholars have noted a particular trend on the Court of failing or refusing to cite Chevron in immigration cases. ${ }^{228}$ No immigration exception to Chevron has been formally announced, and the Court does still cite it in some immigration cases, ${ }^{229}$ but some scholars have suggested it can now be added to the categories of explicit exceptions already established. ${ }^{230}$ As Michael Kagan describes the Court's approach in a 2019 case:

${ }^{221}$ See Thomas W. Merrill, Judicial Deference to Executive Precedent, 101 YALE L.J. 969, 980-81 (1992).

${ }^{222}$ See Jellum, supra note 9 at 772.

${ }^{223}$ See infra Table 1 and citations. Note that this count does not include Kisor v. Wilkie, 139 S. Ct. 2400 (2019), which extensively cites Chevron but is instead an application of the related Auer/Seminole Rock deference standard for agency interpretations of their own regulations.

${ }^{224}$ See Jellum, supra note 9 at 773.

225 See Adam Feldman, Empirical SCOTUS: Something We Haven't Seen in the Supreme Court Since the Civil War, SCOTUSBLOG (Apr. 16, 2020), https://www.scotusblog.com/2020/04/empirical-scotus-somethingwe-havent-seen-in-the-supreme-court-since-the-civil-war/ (describing long-term decline in the number of cases the Court decides).

${ }^{226}$ See, e.g., Nielsen v. Preap, 139 S. Ct. 954 (2019); BNSF Ry. Co. v. Loos, 139 S. Ct. 893 (2019); Little Sisters of the Poor Saints Peter \& Paul Home v. Pennsylvania, 140 S. Ct. 2367 (2020).

${ }^{227}$ See supra text and accompanying notes Section III.D.

${ }_{228}$ See generally Michael Kagan, Chevron's Liberty Exception, 104 Iowa L. REV. 491 (2019).

${ }^{229}$ See, e.g., Pereira v. Sessions, 138 S. Ct. 2105 (2018).

230 See Amy L. Moore, Slouching Towards Oblivion: Divergent Implementation and Potential Exodus of Chevron Analysis in the Supreme Court's Interpretation of Immigration Law, 87 UMKC L. REV. 549 (2019) (arguing the Court's refusal to cite Chevron in immigration contexts is due in part to overlap with the criminal law exclusion). See also Shoba Sivaprasad Wadhia \& Christopher J. Walker, The Case Against Chevron Deference in Immigration Adjudication, 70 DUKE L.J. (forthcoming 2021), https://papers.ssrn.com/abstract=3662827 (arguing the exception is appropriate). 
The statutory interpretation problem was close enough question that it divided the Supreme Court 5-4. The Solicitor General spent three pages in his opening brief arguing for Chevron deference, and then another three pages on it in his reply. The Respondents argued strongly that Chevron should not apply. Chevron seemed important to everyone involved. Except for the nine who mattered most. They acted like Chevron doesn't exist. ${ }^{231}$

The Court's recent decision, sans Chevron cite, in Little Sisters of the Poor $v$. Pennsylvania ${ }^{232}$ is of particular note. There, the Court considered longstanding and controversial agency interpretations of the Affordable Care Act, but the majority opinion makes no mention of Chevron specifically or the weight of the agency's views more generally. ${ }^{233}$ This is perhaps no surprise given that its author is long-time Chevron critic Justice Thomas, but in other contexts (about which more below), Thomas has noted his objections to Chevron in dissent or in a concurrence in the judgment. The burden of retaining votes for a majority opinion likely meant such an attack was off the table in Little Sisters. Thomas' solution was simply to ignore Chevron. This omission did not escape Justice Kagan's attention; in her concurrence in the judgment, she argues "Chevron deference was built for cases like these." 234

Third and finally, when the court has cited Chevron in recent years, it has not helped agencies much, if at all. The Court has considered an agency's interpretation of a statute and cited Chevron in the majority opinion in 15 cases decided since Michigan and King in 2015 (see table). In only one of those 15, Cuozzo Speed Technologies v. Lee, did the Court deferred to the agency's interpretation. ${ }^{235}$ In two further cases, the Court agreed with the agency's interpretation, but held that deference was irrelevant because the statute's meaning was clear (in other words, the agency won but Chevron was irrelevant to the outcome). ${ }^{236}$

In the remaining 12 cases, the Court rejected agency interpretations and denied Chevron deference, either because a majority of Justices thought statute was clearly contrary to the agency's interpretation (Step One) or because some exception to Chevron took it out of the doctrine's scope. ${ }^{237}$ Three out of fifteen cases is not a good success rate for agencies; in fact no agency has won a Chevron case in more than three years, since Coventry Health Care of Missouri v. Nevils was decided in April 2017. Moreover, controlling the outcome of one out of fifteen cases is slim pickings for a doctrine that is alleged to be (and once was) so important. A sample size of fifteen may be too small to draw firm conclusions about what rate to expect in the future. But it is not a good sign for Chevron.

${ }^{231}$ See Michael Kagan, Chevron Goes Missing in an Immigration Case. Again, Yale J. ON REg. NoticE \& COMMENT (Mar. 19, 2019), https://www.yalejreg.com/nc/chevron-goes-missing-in-an-immigration-case-again/.

${ }^{232}$ Little Sisters of the Poor Saints Peter \& Paul Home v. Pennsylvania, 140 S. Ct. 2367 (2020).

${ }^{233} \mathrm{Id}$. at $2372-74$.

${ }^{234} I d$. at 2397 (Kagan, J., concurring in the judgment).

235136 S. Ct. 2131, 2142-43 (2016).

${ }^{236}$ See infra Table 1.

${ }^{237}$ See infra Table 1. 
When examined in more detail, these cases all illustrate how far Chevron deference has declined.

\begin{tabular}{|c|c|c|c|c|c|}
\hline Case & Cite & Author & Votes $^{238}$ & $\begin{array}{c}\text { Agency } \\
\text { win? }\end{array}$ & Defer? \\
\hline F.E.R.C. v. Electric Power Supply Ass'n & $\begin{array}{c}136 \text { S.Ct. } 760 \\
(1 / 25 / 2016)\end{array}$ & Kagan & $6-2$ & Yes & No \\
\hline Kingdomware Technologies, Inc. v. United States & $\begin{array}{c}\text { 136 S.Ct. } 1969 \\
(6 / 16 / 2016)\end{array}$ & Thomas & $9-0$ & No & No \\
\hline Cuozzo Speed Technologies, LLC v. Lee & $\begin{array}{c}\text { 136 S.Ct. } 2131 \\
(6 / 20 / 2016)\end{array}$ & Breyer & $9-0$ & Yes & Yes \\
\hline Encino Motorcars, LLC v. Navarro & $\begin{array}{c}\text { 136 S.Ct. } 2117 \\
(6 / 20 / 2016)\end{array}$ & Kennedy & $7-2$ & No & No \\
\hline Coventry Health Care of Missouri, Inc. v. Nevils & $\begin{array}{c}\text { 137 S.Ct. } 1190 \\
(4 / 18 / 2017)\end{array}$ & Ginsburg & $8-0$ & Yes & No \\
\hline Esquivel-Quintana v. Sessions & $\begin{array}{c}\text { 137 S.Ct. } 1562 \\
(5 / 30 / 2017)\end{array}$ & Thomas & $8-0$ & No & No \\
\hline Digital Realty Trust, Inc. v. Somers & $\begin{array}{l}\text { 138 S.Ct. } 767 \\
(11 / 28 / 2017)\end{array}$ & Ginsburg & $9-0$ & No & No \\
\hline SAS Institute, Inc. v. Iancu & $\begin{array}{c}\text { 138 S.Ct. } 1348 \\
(11 / 27 / 2017)\end{array}$ & Gorsuch & $5-4$ & No & No \\
\hline Epic Systems Corp. v. Lewis & $\begin{array}{c}\text { 138 S.Ct. } 1612 \\
(5 / 21 / 2018)\end{array}$ & Gorsuch & $5-4$ & No & No \\
\hline Wisconsin Central Ltd. v. United States & $\begin{array}{c}\text { 138 S.Ct. } 2067 \\
(6 / 21 / 2018)\end{array}$ & Gorsuch & $5-4$ & No & No \\
\hline Pereira v. Sessions & $\begin{array}{c}\text { 138 S.Ct. } 2105 \\
(6 / 21 / 2018)\end{array}$ & Sotomayor & $8-1$ & No & No \\
\hline Sturgeon v. Frost & $\begin{array}{l}\text { 139 S.Ct. } 1066 \\
(3 / 26 / 2019)\end{array}$ & Kagan & $9-0$ & No & No \\
\hline Smith v. Berryhill & $\begin{array}{l}\text { 139 S.Ct. } 1765 \\
(5 / 28 / 2019)\end{array}$ & Sotomayor & $9-0$ & No & No \\
\hline PDR Network v. Carlton \& Harris Chiropractic & $\begin{array}{c}\text { 139 S.Ct. } 2051 \\
(6 / 20 / 2019)\end{array}$ & Breyer & $9-0$ & No & No \\
\hline County of Maui, Hawaii v. Hawaii Wildlife Fund & $\begin{array}{c}140 \text { S.Ct. } 1462 \\
(4 / 23 / 2020)\end{array}$ & Breyer & $6-3$ & No & No \\
\hline
\end{tabular}

Even in the cases in which the agency prevailed, Chevron deference seems to have played little role. In Cuozzo, the only case in which the majority explicitly granted deference, the agency prevailed 9-0. ${ }^{239}$ Nevertheless, Justice Breyer's conclusion in the

${ }^{238}$ These vote tallies do not separately count concurrences/concurrences in the judgment, which in some cases do not adopt the majority's reasoning with regard to Chevron. See, e.g., Justice Thomas' concurrence in Cuоzzo, 136 S. Ct. 2131, 2148 (2016).

${ }^{239} \mathrm{Id}$. at 2131. 
majority opinion that deference was due prompted a blistering concurrence (if that is not a contradiction in terms) from Justice Thomas, openly questioning Chevron and noting that, in his view, the outcome was dictated by the clear meaning of the statute, not deference. ${ }^{240}$ The Court would almost certainly have reached the same result with or without deference.

In the other two cases in which the agency prevailed, Coventry Health Care v. Nevils and $F E R C$ v. EPSA, Justice Ginsburg and Justice Kagan (respectively) were careful to make clear that Chevron deference played no role in the outcome. ${ }^{241}$ This suggests that applying Chevron deference is toxic on the Court, and risks losing votes for an opinion. Chevron deference is supposed to increase the chances of an agency prevailing by compelling a marginal justice to accept an agency position he or she views as reasonable, but wrong (or at least second-best). Chevron today does the opposite, repelling some of the justices and possibly reducing the chances of agency success.

In the remaining 12 cases in which agency interpretations were rejected by the Court, Chevron deference was denied on a variety of grounds. The most common was simple rejection of the agency interpretation as contrary to clear Congressional intent at Step One, focused almost entirely on the statutory text; the Court decided $7^{242}$ or perhaps $8^{243}$ of these

${ }^{240} I d$. at 2148 (Thomas, J., concurring) (“[T]oday's decision does not rest on Chevron's fiction that ambiguity in a statutory term is best construed as an implicit delegation of power to an administrative agency to determine the bounds of the law. In an appropriate case, this Court should reconsider that fiction of Chevron and its progeny." (citing Michigan v. EPA, 576 U.S. 743, 760 (2015) (Thomas, J., concurring)).

${ }^{241}$ See Coventry Health Care of Mo., Inc. v. Nevils, 137 S. Ct. 1190, 1198 n.3 (2017) ("Because the statute alone resolves this dispute, we need not consider whether Chevron deference attaches"); F.E.R.C. v. Elec. Power Supply Ass'n, 136 S. Ct. 760, 773 n.5 ("Because we think FERC's authority clear, we need not address the Government's alternative contention that FERC's interpretation of the statute is entitled to deference under Chevron.").

${ }^{242}$ See Kingdomware Techs., Inc. v. United States, 136 S. Ct 1969, 1979 (2016) ("[W]e do not defer to the agency when the statute is unambiguous."); Esquivel-Quintana v. Sessions, 137 S. Ct. 1562, 1572 (2017) ("[T]he statute, read in context, unambiguously forecloses the Board's interpretation."); Digital Realty Tr., Inc. v. Somers, 138 S. Ct. 767, 782 (2017) ("Because 'Congress has directly spoken to the precise question at issue' . . we do not accord deference to the contrary view advanced by the SEC." (quoting Chevron U.S.A. Inc. v. Nat. Res. Def. Council, Inc., 467 U.S. 837, 842 (1984)); SAS Inst., Inc. v. Iancu, 138 S. Ct. 1348, 1358 (2017) ("[A]fter applying traditional tools of interpretation here, we are left with no uncertainty that could warrant deference."); Wis. Cent. Ltd. v. United States, 138 S. Ct. 2067, 2074 (2018) ("[I]n light of all the textual and structural clues before us, we think it's clear enough that the term 'money' excludes 'stock,' leaving no ambiguity for the agency to fill."); Pereira v. Sessions, 138 S. Ct. 2105, 2114 (2018) ("[T] he Court need not resort to Chevron deference ... for Congress has supplied a clear and unambiguous answer to the interpretive question at hand."); Sturgeon v. Frost, 139 S. Ct. 1066, 1080 n.3 (2019) ("Because we see, for the reasons given below, no ambiguity as to Section 103(c)'s meaning, we cannot give deference to the Park Service's contrary construction.").

${ }^{243}$ The most recent Chevron case, County of Maui, applies Chevron somewhat cryptically; it is unclear if the agency loses at Step One or Step Two. Justice Breyer's majority opinion notes that no party has asked for Chevron deference, before finding that (nevertheless) EPA's reading "is neither persuasive nor reasonable," terms that appear in Chevron's second step. But the opinion's subsequent statutory analysis supporting this interpretation is indistinguishable from typical Step One analysis ("EPA's oblique argument ... cannot overcome the statute's structure, its purposes, or the text of the provisions that actually govern."). See County 
cases at Step One. Other grounds for denying deference included application of the "stay in your lane" principle, ${ }^{244}$ Mead's "force of law" requirement, ${ }^{245}$ and the exclusion for interpretations affecting the scope of judicial review. ${ }^{246}$ Another rejected Chevron deference due to the agency's procedural error. ${ }^{247}$ These opinions withholding deference were authored by seven different Justices: Sotomayor, Kagan, Breyer, Gorsuch, Ginsburg, Thomas, and Kennedy. ${ }^{248}$ No Justice wrote more majority opinions than Gorsuch's three. This suggests a broad consensus in favor of a robust, nearly all-encompassing, and predominantly textualist Step One (though again the sample size warrants caution).

One case established what appears to be a new Chevron exception, denying deference to an independent agency's interpretation of a statute because the Solicitor General in an amicus brief offered a contrary interpretation. ${ }^{249}$ This has implications for Presidential authority over independent agencies; apparently the President (and/or DOJ leadership) may deny an agency access to Chevron deference to their interpretations of statutes by taking a position in briefs. This contrasts with the Court's longstanding position that agency litigating positions do not get deference because they lack the force of law and/or have inadequate procedural underpinnings. ${ }^{250}$ Apparently the procedural requirements for denying deference are much lower than those for obtaining it.

In short, the Court has shown almost no inclination in recent years to defer to agency statutory interpretations. Chevron's two-step inquiry to some extent remains the lingua franca of agency statutory interpretation cases, but not always; the Court regularly fails to cite it at all. Even when it does, deference is rarely if ever actually available. No agency has won a case at SCOTUS in which the majority cited Chevron in more than three years.

of Maui, Haw. v. Haw. Wildlife Fund, 140 S. Ct. 1462, 1474-75 (2020). Some have read County of Maui to adopt a "Chevron waiver" doctrine under which deference is not given if an agency fails to ask for it. See Kristin E. Hickman, County of Maui \& Chevron Waiver-Let's Not Get Carried Away, YALE J. ON REg. NoticE \& CoMment (Apr. 27, 2020), https://www.yalejreg.com/nc/county-of-maui-chevron-waiver-lets-not-get-carriedaway/.

${ }^{244}$ See Epic Sys. Corp v. Lewis, 138 S. Ct. 1612, 1629 (2018) (“[O]n no account might we agree that Congress implicitly delegated to an agency authority to address the meaning of a second statute it does not administer.").

${ }^{245}$ See PDR Network, LLC v. Carlton \& Harris Chiropractic, Inc., 139 S. Ct. 2051, 2056 (2019) (holding lower court not bound by an agency interpretive rule that had not undergone notice and comment, but refusing to reach whether such an agency interpretation should be given Chevron deference).

${ }^{246}$ See Smith v. Berryhill, 139 S. Ct. 1765, 1778 (2019) ("The scope of judicial review, meanwhile, is hardly the kind of question that the Court presumes that Congress implicitly delegated to an agency.").

247 See Encino Motorcars, LLC v. Navarro, 136 S. Ct. 2117, 2125 (2016) ("Chevron deference is not warranted where the regulation is 'procedurally defective' - that is, where the agency errs by failing to follow the correct procedures in issuing the regulation.").

${ }^{248}$ See supra Table 1.

${ }^{249}$ See Epic Systems, 138 S. Ct. at 1630 ("[H]ere the Executive seems of two minds, for we have received competing briefs from the Board and from the United States (through the Solicitor General) disputing the meaning of the NLRA. And whatever argument might be mustered for deferring to the Executive on grounds of political accountability, surely it becomes a garble when the Executive speaks from both sides of its mouth, articulating no single position on which it might be held accountable.").

${ }^{250}$ See Bowen v. Georgetown Univ. Hosp., 488 U.S. 204, 212 (1988). 
Agencies went 0-10 over that period. As noted above in the context of Massachusetts v. EPA, $U A R G$, and Brown \& Williamson, the modern understanding of Step One at the Court is broad enough to allow most any result. That makes the deference available at Step Two almost impossible for agencies to access.

Majority opinions in recent years have mostly dispensed with Chevron quickly, resolving cases at Step One such that deference never comes into play. This should perhaps come as no surprise given the expansion of Step One, but the open antipathy by a faction of the Court to Chevron makes appeal to deference doctrines at least less useful for attracting votes, and possibly counterproductive. This is particularly ironic because Chevron's ability to drive case outcomes was its ability to attract (or compel) votes in favor of the agency's interpretation by justices who disagreed with that interpretation. If Chevron meant anything, it was that some justices would vote to uphold the agency interpretation under deference who would not have done so under a de novo standard (or perhaps under Skidmore). ${ }^{251}$

Now, citing Chevron appears to have the opposite effect, driving away votes; only supermajorities are able to uphold agency interpretations while explicitly granting deference. Narrow agency wins, it seems, have to fall within an explicit Chevron exclusion or be framed as Step One cases, in which the agency reading is unambiguously correct. Two (or perhaps three) justices seem unwilling to join an opinion deferring to an agency under Chevron even if they agree with the result. ${ }^{252} \mathrm{~A}$ good portion of the time the Court does not cite Chevron in agency statutory interpretation cases at all. Even when there are sufficient votes to support the agency's position, the Court seems reluctant to admit that deference plays any role in the result. Increasingly, it seems, it does not.

In short, there appears to be little if any scope for Chevron deference at the Supreme Court level. Chevron lives but deference is dead.

It is important to reiterate that this analysis is restricted to the Supreme Court. Chevron's erosion appears to be much more severe and rapid there than in the lower federal courts. Recent work by Kent Barnett and Christopher Walker indicates that Chevron still has substantial influence on case outcomes in the circuit courts. ${ }^{253}$ As they observe, there are big differences between "Chevron Supreme" and "Chevron Regular." 254 One might therefore conclude that the decline of deference at the Supreme Court is not that important. Five cases or so per term isn't very much. That may be true, but the cases that reach the Court are the highest-profile and most significant. Major public policy issues like health care, climate change, and immigration involve agency action for which, at the margin, statutory interpretation questions abound. Also, I am skeptical that a different Chevron Regular and Chevron Supreme can persist forever. Now-Justice Kavanaugh, whose

${ }^{251}$ Some scholars have characterized Chevron in this sense as a voting rule, requiring a supermajority to overrule agency interpretations. See Jacob E. Gersen \& Adrian Vermeule, Chevron as a Voting Rule, 116 YALE L.J. 676 (2007).

${ }^{252}$ See, e.g., Cuozzo Speed Techs., LLC v. Lee, 136 S. Ct. 2131, 2148 (2016) (Thomas, J., concurring).

${ }^{253}$ See Barnett \& Walker, supra note 14.

${ }^{254} \mathrm{Id}$. at 1 . 
criticisms of Chevron are detailed below, readily observed while still on the DC Circuit that "the Supreme Court itself has been reining in Chevron in the last few years." ${ }^{255}$ Now-Justice Gorsuch more or less begged the Court to revisit Chevron while on the Tenth Circuit. ${ }^{256} \mathrm{~A}$ survey of appellate judges in 2018 also suggests significant skepticism about Chevron. ${ }^{257}$

\section{Chevron Under Attack}

\section{The Old Guard}

At the same time as the Court has consistently denied deference to agencies at the Supreme Court, open criticism of Chevron has become en vogue among some Justices. Concurring in Michigan, Justice Thomas criticized Chevron as inconsistent with Marbury and Article III, stopping just short of calling for it to be overturned: "[W]e seem to be straying further and further from the Constitution without so much as pausing to ask why. We should stop to consider that document before blithely giving the force of law to any other agency 'interpretations' of federal statutes." 258 Since Michigan Thomas has continued to call for Chevron to be reconsidered at every opportunity, ${ }^{259}$ most recently recommending not only Chevron but his own opinion in Brand $X$ (extending deference to agency interpretations that contradict early judicial interpretations) to be rejected. ${ }^{260}$

Justice Kennedy's concurring opinion in Pereira v. Sessions, published a week before his retirement, was written explicitly "to note [his] concern with the way in which the Court's opinion in [Chevron] has come to be understood and applied." ${ }^{261}$ For Justice Kennedy:

The type of reflexive deference exhibited in some of these cases is troubling ... Given the concerns raised by some Members of this Court, it seems necessary and appropriate to reconsider, in an appropriate case, the premises that underlie Chevron and how courts have implemented that decision. The proper rules for interpreting statutes and determining agency jurisdiction and substantive agency powers should accord with constitutional separation-of-powers principles and the function and province of the Judiciary. ${ }^{262}$

${ }^{255}$ Kavanaugh, supra note 32, at 2151.

256 See Gutierrez-Brizuela v. Lynch, 834 F.3d 1142, 1149 (10th Cir. 2016) (Gorsuch, J., concurring) ("Chevron and Brand $X$ permit executive bureaucracies to swallow huge amounts of core judicial and legislative power and concentrate federal power in a way that seems more than a little difficult to square with the Constitution of the framers' design. Maybe the time has come to face the behemoth.").

${ }^{257}$ Abbe R. Gluck \& Richard A. Posner, Statutory Interpretation on the Bench: A Survey of Forty-Two Judges on the Federal Courts of Appeals, 131 HARV. L. REv. 1300, 1348 (2018) ("Although every judge we interviewed told us that he or she was bound by Chevron-and all but one of the judges did apply that rule in opinionsmost of the judges we interviewed do not favor the Chevron rule.").

${ }^{258}$ Michigan v. EPA, 576 U.S. 743, 763 (2015) (Thomas, J., concurring).

${ }^{259}$ See, e.g., Cuozzo Speed Techs., LLC v. Lee, 136 S. Ct. 2131, 2148 (2016) (Thomas, J., concurring).

${ }^{260}$ Baldwin v. United States, 140 S. Ct. 690 (2020) (Mem.) (Thomas, J., dissenting from denial of certiorari).

${ }^{261}$ Pereira v. Sessions, 138 S. Ct. 2105, 2120 (2018) (Kennedy, J., concurring).

${ }^{262} I d$. 
Justice Kennedy's concurrence is somewhat puzzling, or at least the venue he chose for it is. In Pereira, the majority in an opinion by Justice Sotomayor denied deference on Step One grounds ${ }^{263}$ - hardly the "reflexive deference" that Kennedy criticizes. If Chevron deference was ever "reflexive", it certainly wasn't by 2017 when Pereira was decided. Justice Alito's dissent in the same case makes for a more effective Chevron critique. He would have upheld the agency's interpretation, and criticizes the majority for failing to defer. ${ }^{264}$ This move may be rhetorically effective, trolling the liberal justices that have historically been more willing to defer, but should not be taken as evidence that Alito really values Chevron deference; in the same dissent he calls it "once celebrated, and now increasingly maligned precedent." 265 Occasionally Justice Alito joins in the Chevronbashing, though he has not called for it to be rejected.

Critique of Chevron is not entirely restricted to the Court's conservative/Republicanappointed Justices. Justice Breyer has long advocated a narrow reading of Chevron, dating back to his 1986 article. ${ }^{266}$ More recently, he argued in dissent in SAS Institute for Chevron to be treated as a mere "a rule of thumb" guided in part by the degree to which the interpreting agency has brought to bear its unique expertise, rather than a "rigid, blackletter rule of law." 267 The three other liberal/Democratic-appointed Justices joined the opinion. ${ }^{268}$

Chevron's cousin, deference to agency interpretations of their own regulation under Auer v. Robbins ${ }^{269}$ and Bowles v. Seminole Rock \& Sand Co., ${ }^{270}$ has come under particularly strong criticism. Most notable is Justice Scalia's concurrence in the judgment in Perez $v$. Mortgage Bankers Ass' $n$, in which he called for Auer to be overturned. ${ }^{271}$ In critiquing Auer, however, Scalia suggested that his longstanding support for Chevron has perhaps waned as well. ${ }^{272}$ Scalia was troubled by agencies issuance of "interpretive rules" that in effect create new law, and by courts' willingness to defer to agencies when these rules are litigated. ${ }^{273}$

${ }^{263} \mathrm{Id}$. at 2114

${ }^{264} I d$. at 2121 (Alito, J., dissenting).

${ }^{265} \mathrm{Id}$.

${ }^{266}$ See Breyer, supra note 22, at 373 ("To read Chevron as laying down a blanket rule, applicable to all agency interpretations of law, such as 'always defer to the agency when the statute is silent,' would be seriously overbroad, counterproductive and sometimes senseless.").

${ }^{267}$ SAS Inst., Inc. v. Iancu, 138 S. Ct. 1348, 1360 (2017) (Ginsburg, J., Breyer, J., Sotomayor, J., \& Kagan, J., dissenting).

${ }^{268} I d$.

${ }^{269} 519$ U.S. 452 (1997).

270325 U.S. 410 (1945).

${ }^{271}$ Perez v. Mortg. Bankers Ass'n, 575 U.S. 92, 108 (2015) (Scalia, J., concurring in part \& concurring in the judgment).

${ }^{272} I d$. at 110 (Scalia, J., concurring in the judgment) (quoting Chevron U.S.A. Inc. v. Nat. Res. Def. Council, Inc., 467 U.S. 837, 842-43 (1984)) ("Heedless of the original design of the APA, we have developed an elaborate law of deference to agencies' interpretations of statutes and regulations. Never mentioning $§ 706$ 's directive that the 'reviewing court ... interpret... statutory provisions,' we have held that agencies may authoritatively resolve ambiguities in statutes.").

${ }^{273} I d$. at 111. 
For Scalia, Auer deference is the source of much of the trouble, but for him the problem "is bad enough, and perhaps insoluble if Chevron is not to be uprooted, with respect to interpretive rules setting forth agency interpretation of statutes." 274 Scalia seems to be whistling past Chevron's graveyard. Justice Alito has publicly claimed that Scalia had begun to question the wisdom of Chevron before his death in 2015. ${ }^{275}$

\section{Justice Gorsuch}

Though of course we will never know how Scalia's views on Chevron would have evolved, the justice who replaced him has made his skepticism clear. Justice Kennedy's concurrence in Pereira cites Chief Justice Roberts' dissent in City of Arlington and Justice Thomas' concurrence in Michigan as examples of "concerns raised by some Members of this Court" about Chevron; it also cites then-10th Circuit Judge Gorsuch's concurring opinion in Gutierrez-Brizuela v. Lynch (2016). ${ }^{276}$ In that case, the 10th Circuit, in an opinion by Judge Gorsuch, ruled in favor of the agency's interpretation of a statute, applying Chevron deference. ${ }^{277}$ Judge Gorsuch also wrote a concurrence to his own opinion to criticize that deference, calling alleged tension between Chevron and the Constitution "an elephant in the room" and suggesting that "[m]aybe the time has come to face the behemoth." ${ }^{278}$ The concurrence is a sweeping and detailed phillipic against Chevron; in particular it uses the various exceptions to Chevron, such as the exclusion of criminal statutes and Mead, lack of clarity about the tools available at Step One, and other inconsistencies to critique the foundational assumptions of implied delegation and agency expertise that undergird deference. ${ }^{279}$ (Not everyone is a fan, however: Asher Steinberg calls the Gutierrez-Brizuela concurrence "the most half-baked critique of Chevron one is likely to encounter outside of a law school classroom.") $)^{280}$

In any case, most of the concurrence reads like a Supreme Court opinion winding up to overrule Chevron. But of course all then-Judge Gorsuch can do at the end is send a plea to the Court, asking it to do what he cannot. As he plaintively puts it, "[w]e managed to live with the administrative state before Chevron. We could do it again. Put simply, it seems

${ }^{274} I d$.

${ }^{275}$ See Adam White, More on Justice Scalia's Doubts About Chevron, YALE J. ON REg. NotiCE \& CommEnT (Nov. 17, 2016), https://www.yalejreg.com/nc/more-on-justice-scalias-doubts-about-chevron/ ("Before his death, Nino was also rethinking the whole question of Chevron deference.").

${ }^{276}$ Pereira v. Sessions, 138 S. Ct. 2105, 2120 (2018) (Kennedy, J., concurring).

277 Gutierrez-Brizuela v. Lynch, 834 F.3d 1142, 1144 (10th Cir. 2016).

${ }^{278} I d$. at 1149-58 (Judge Gorsuch, concurring) (Gorsuch evidently loves big metaphors for Chevron, also calling it a "colossus").

${ }^{279} \mathrm{Id}$.

${ }^{280}$ See Asher Steinberg, Judge Gorsuch and Chevron Doctrine Part III: The Gutierrez-Brizuela Concurring Opinion, YALE J. ON REG. NOTICE \& COMMENT (Mar. 29, 2017), http://yalejreg.com/nc/judge-gorsuch-andchevron-doctrine-part-ii-the-gutierrez-brizuela-concurring-opinion-by-asher-steinberg/. 
to me that in a world without Chevron very little would change-except perhaps the most important things." 281

Of course, now-Justice Gorsuch will play a role in any decision on whether to overturn Chevron. His concurrence in Gutierrez-Brizuela v. Lynch establishes him as a clear vote to do so and, since joining the court, he has joined Justice Thomas as Chevron's most consistent critics. In Epic Systems v. Lewis, Gorsuch (writing for the majority) applies Chevron, but not before noting that "no party ... has asked us to reconsider Chevron deference." ${ }^{282}$ This is hard to interpret as anything other than an invitation to litigants to challenge Chevron directly in the future. In SAS Institute v. Iancu, Gorsuch again punts invitingly: "whether Chevron should remain is a question we may leave for another day." 283 In BNSF v. Loos, Gorsuch (in a dissenting opinion joined by Justice Thomas) refers to "mounting criticism of Chevron deference" and notes with satisfaction the litigants' reluctance, and majority opinion's refusal, to rely on it. ${ }^{284}$ And most recently in $P D R$ Network v. Carlton \& Harris Chiropractic, Gorsuch joins Thomas in a concurrence in the judgment that questions the constitutionality of Chevron, alleging it is possibly inconsistent with the Vesting Clause in Article III. ${ }^{285}$ Justices Thomas and Gorsuch now seem to take shots at Chevron almost every time the opportunity to do so arises. ${ }^{286}$

\section{Justice Kavanaugh}

What about the newest Justice? Brett Kavanaugh's views on Chevron are more nuanced than Justice Gorsuch's, though broadly still skeptical. In his previous position on the DC Circuit, Kavanaugh participated in a large number of administrative law cases, in fact the majority of his written opinions at that level reviewed agency decisions. ${ }^{287}$ In those cases, Kavanaugh's treatment of agencies did not stand out among his peers as particularly skeptical (or deferential); he voted in favor of agency interpretations roughly $75 \%$ of the time $(25 / 33$ cases $) .{ }^{288}$ This is slightly more deferential than all judges in their data set $(71 \%)^{289}$ and, of course, substantially more deferential than the Supreme Court at the time he joined. ${ }^{290}$ Of course, Kavanaugh was constrained by Supreme Court doctrine (including

${ }^{281}$ Gutierrez-Brizuela, 834 F.3d at 1158.

${ }^{282}$ Epic Sys. Corp. v. Lewis, 138 S. Ct. 1612, 1631-32 (2018).

${ }^{283}$ SAS Inst., Inc. v. Iancu, 138 S. Ct. 1348, 1358 (2017).

${ }^{284}$ BNSF Ry. Co. v. Loos, 139 S. Ct. 893, 904-09 (2019) (Gorsuch, J., dissenting).

${ }^{285}$ PDR Network, LLC v. Carlton \& Harris Chiropractic, Inc., 139 S. Ct. 2051, 2056-57 (2019) (Thomas, J., \& Gorsuch, J., concurring in the judgment).

${ }^{286}$ But see Wis. Cent. Ltd. v. United States, 138 S. Ct. 2067, 2074 (2018) (majority opinion by Gorsuch featuring a straightforward, albeit cursory, application of Chevron, dismissing agency position at Step One).

287 See Adam Feldman, The Next Nominee to the Supreme Court, EMPIRICAL SCOTUS (Dec. 7, 2017), https://empiricalscotus.com/2017/12/07/the-next-nominee/.

${ }^{288}$ See Kent Barnett et al., Judge Kavanaugh, Chevron Deference, and the Supreme Court, REg. REv. (Sept. 3, 2018) https://www.theregreview.org/2018/09/03/barnett-boyd-walker-kavanaugh-chevron-deference-supremecourt/.

${ }^{289} \mathrm{Id}$.

${ }^{290}$ See supra Table 1. 
Chevron) while on the DC Circuit, so this pattern does not necessarily reflect how he views that doctrine. But on the other hand there is no Guttierrez-Brizuela anti-Chevron opinion in Kavanaugh's DC Circuit record, despite many opportunities.

Kavanaugh's most extensive comments on Chevron come not from an opinion but in a 2016 book review in the Harvard Law Review. ${ }^{291}$ In it, Kavanaugh criticized Chevron among other interpretive canons and doctrines as distractions from the core judicial task of textualist statutory interpretation. ${ }^{292}$ Chevron, he argued, is an "atextual invention by courts" that shifts a too much power to agencies. ${ }^{293}$ Nevertheless, he argued, "Chevron makes a lot of sense in certain circumstances." ${ }^{294}$ Chevron should not be rejected entirely, he argued, but rather should be limited to "cases involving statutes using broad and openended terms" rather than "a specific statutory term or phrase" (though he offers little guidance for telling the difference). ${ }^{295}$

Some scholars claim Kavanaugh's record shows he has "embraced a strong version" of the major questions doctrine. ${ }^{296}$ In United States Telecom Association v. FCC, Kavanaugh argued in dissent from denial of rehearing en banc that the FCC lacked clear authorization from Congress to issue rules on net neutrality, and that deference was not due for this "major rule." 297 Dan Deacon argues this "major rules" variant is no mere restatement of the existing major questions doctrine, but rather an expansion and "weaponization" of it. ${ }^{298}$ In Kavanaugh's framing, agencies cannot take "major regulatory action[s] without clear congressional authorization." ${ }^{299}$ This is different and, Deacon argues, far broader than the Supreme Court's major questions doctrine. ${ }^{300}$ It also, he argues, imposes an anti-regulatory bias. ${ }^{301}$ Jody Freeman notes that Kavanaugh focused questioning in oral arguments during the DC Circuit's review of the Obama EPA's Clean Power Plan on whether it was too significant to qualify for deference. ${ }^{302}$

Additional evidence that Justice Kavanaugh may take a narrow view of deference is his view on the amount of certainty needed to judicially dispose of an interpretive question

${ }^{291}$ Kavanaugh, supra note 32.

${ }^{292} I d$. at 2150.

${ }^{293} \mathrm{Id}$. at $2150-51$.

${ }^{294} \mathrm{Id}$. at 2152

${ }^{295} \mathrm{Id}$. at $2153-54$.

296 See Christopher J. Walker, Judge Kavanaugh on Administrative Law and Separation of Powers, SCOTUSBLOG (July 26, 2018), https://www.scotusblog.com/2018/07/kavanaugh-on-administrative-law-andseparation-of-powers/.

${ }^{297}$ See U.S. Telecom Ass'n v. FCC, 855 F.3d 381, 417 (2017) (Kavanaugh, J., dissenting from denial of rehearing en banc).

298 Daniel Deacon, Judge Kavanaugh and "Weaponized Administrative Law," YALE J. ON REgULATION NoticE \& COMMENT (July 11, 2018), https://www.yalejreg.com/nc/judge-kavanaugh-and-weaponizedadministrative-law-by-daniel-deacon/.

${ }^{299}$ U.S. Telecom Ass'n, 855 F.3d at 420 (2017) (Kavanaugh, J., dissenting from denial of rehearing en banc).

${ }^{300}$ Deacon, supra note 298.

${ }^{301} I d$.

302 See Amanda Reilly, Would Kavanaugh Limit the Chevron Doctrine?, GreENWIRE (July 10, 2018), https://www.eenews.net/stories/1060088675. 
rather than defer to an agency (i.e. decide at Chevron Step One). In Kavanaugh's view, some judges might require $90 \%$ certainty, but "I probably apply something approaching a $65 / 35$ or $60 / 40$ rule. In other words, if it is $60 / 40$ clear, it is not ambiguous, and I do not resort to [Chevron deference]." ${ }^{303}$ This suggests a very expansive view of Step One, in line with the Supreme Court's current vision (or perhaps even more expansive). A statutory provision more ambiguous than Kavanaugh's 60/40 certainty is near or equivalent to "absolute equipoise"; as Justice Scalia observed in 1989, a Chevron deference doctrine restricted to such cases "becomes virtually meaningless." 304 Nevertheless, Kavanaugh cannot be right that his approach to Step One is so different from other judges; as noted above, he defers to agency interpretations slightly more often than average. ${ }^{305}$ Perhaps his self-judgment is inaccurate, or perhaps it reflects how he would really like to rule, if he had the authority to do so (as he now does on the Court). Alternatively, maybe it is his assessment of other judges that is wrong, and far less than $90 \%$ certainty is typically needed to deny deference. The Supreme Court cases suggest as much, but the persistently high success rate of agencies in the circuit courts does not.

So far, Justice Kavanaugh has not said much about Chevron from the Supreme Court bench. His most notable non-statement is his refusal to join Justice Thomas' Chevron critique in PDR; he wrote his own concurrence in the judgement, which Thomas and Gorsuch joined, ${ }^{306}$ but he was unwilling to join theirs. That could suggest he is not as critical as they are of deference, but I would be cautious before reading much into it at all, much less a change from Justice Kavanaugh's earlier positions. Kavanaugh's most significant statement on agencies' relationship with the Court more generally is his dissent from denial of certiorari in Paul v. US, in which he urges adoption of a more robust nondelegation doctrine (as advocated in Justice Gorsuch's Gundy dissent). ${ }^{307}$ In this dissent, he echoes his existing concerns with agencies that "exercise regulatory authority over a major policy question of great economic and political importance" and citing in support $U A R G$, Brown $\&$ Williamson, and $M C I .{ }^{308}$ This suggests a close connection between nondelegation and the major questions doctrine that should chill any ambitious regulator to the bone. As Andy Hessick has put it, "Chevron is just a battle, and nondelegation is the war." 309 That said, the implications for Chevron specifically are as yet unclear.

303 Brett Kavanaugh, The Joseph Story Distinguished Lecture, HERITAGe Found. (Oct. 25, 2017), https://www.heritage.org/josephstory2017. See also Walker, supra note 296 (quoting relevant part of the lecture and discussing implications for Chevron).

${ }^{304}$ See Scalia, supra note 19, at 520.

${ }^{305}$ See Barnett et al., supra note 288.

306 PDR Network, LLC v. Carlton \& Harris Chiropractic, Inc., 139 S. Ct. 2051, 2057-58 (2019) (Kavanaugh, J., Thomas, J., Alito, J., \& Gorsuch, J., concurring in the judgment).

${ }^{307}$ Paul v. United States, 140 S. Ct. 342 (2019) (Mem.) (Kavanaugh, J., dissenting from denial of certiorari) ("I write separately because Justice Gorsuch's scholarly analysis of the Constitution's nondelegation doctrine in his Gundy dissent may warrant further consideration in future cases.").

${ }^{308} I d$.

${ }^{309}$ Andy Hessick (@AndyHessick), TwITTER (Feb. 28, 2020, 1:30 PM), https://twitter.com/AndyHessick/ status/1233459391346728960. 
It is impossible to be sure how Kavanaugh would vote if given the opportunity to overturn Chevron; and it is harder to guess than with Gorsuch and Thomas, who have made their opposition clear. But Kavanaugh's record does make it clear that he supports continuing the long process of constraining and weakening Chevron. Limiting Chevron to "broad and open-ended terms", as he suggested in his Harvard Law Review article, except for "major rules" as he suggested in USTA v. FCC, would push that narrowing project even further than it has gone already. It might not make much difference in practice, given the low rate of deference to agency interpretations already evident on the Court, but it would make Chevron's decline more obvious.

\section{Outside Voices}

Chevron has always had its critics. ${ }^{310}$ But that criticism has increased notably in recent years, ${ }^{311}$ likely driven by (and possibly itself driving) the critiques within the Court. Cass Sunstein has characterized Chevron as "under siege." 312 Criticism has come from academics, ${ }^{313}$ interest groups, ${ }^{314}$ and even from Congress itself. ${ }^{315}$ Some states have recently moved to reject deference to agency interpretations of statutes in state courts ${ }^{316}$ (though

${ }^{310}$ Among early academic criticisms, see, for example, Cynthia R. Farina, Statutory Interpretation and the Balance of Power in the Administrative State, 89 Colum. L. REV. 452, 456 (1989). See also Sanford N. CaustEllenbogen, Blank Checks: Restoring the Balance of Powers in the Post-Chevron Era, 32 B.C.L. REv. 757, 761 (1991) (A "strong reading of Chevron should be rejected because it is unconstitutional, represents poor political theory, produces bad policy outcomes, and rests on shaky doctrinal foundations. Chevron is based on two questionable premises ....").

${ }^{311}$ See, e.g., Christopher J. Walker, The Federalist Society's Chevron Deference Dilemma, FEDERALIST Soc'Y L. \& LIBERTY (Apr. 3, 2018), https://lawliberty.org/the-federalist-societys-chevron-deference-dilemma/ ("In recent years, there has been a growing call to eliminate Chevron deference. This call has come from the Hill, the federal bench, and the legal academy. Last year it was front and center during the Senate Judiciary Committee's hearing on Neil Gorsuch's nomination to the Supreme Court ....").

312 See, e.g., Cass R. Sunstein, Chevron as Law, 107 GEO. L.J. 1613, 1613 (2019).

${ }^{313}$ See, e.g., Jack M. Beermann, End the Failed Chevron Experiment Now: How Chevron Has Failed and Why It Can and Should Be Overruled, 42 ConN. L. REV. 779 (2010). See also Randy J. Kozel, Statutory Interpretation, Administrative Deference, and the Law of Stare Decisis, 97 TEX. L. REV. 1125 (2019) (arguing stare decisis should not be a barrier to overturning Chevron).

${ }^{314}$ See Joseph Postell \& Paul Larkin Jr., Not Above the Law: Ending the Misguided Chevron-Auer Deference Regime, HERITAGE FOUND. (Sept. 7, 2018), https://www.heritage.org/courts/report/not-above-the-law-endingthe-misguided-chevron-auer-deference-regime.

315 See Brent Owen, U.S. Congress Considers Law That Would Overturn Chevron Deference, VI NAT'L L. REV., No. 224, Aug. 11, 2016, https://www.natlawreview.com/article/us-congress-considers-law-would-overturnchevron-deference.

316 See Daniel M. Ortner, The End of Deference: The States That Have Rejected Deference, YALE J. ON REG. Notice \& COMmEnT (Mar. 24, 2020), https://www.yalejreg.com/nc/the-end-of-deference-the-states-thathave-rejected-deference-by-daniel-m-ortner/ ("[W]hile the Supreme Court has chosen incremental reform rather than a more dramatic rejection of deference, several states in recent years have made a different and more dramatic decision. At least seven state supreme courts have issued decisions that decisively reject Chevron or Auer like deference. And two more states have rejected deference via legislation or referendum."). 
others never recognized it). ${ }^{317}$ Some of it has called for Chevron to be rejected entirely, ${ }^{318}$ while some has called for it to be retained but further constrained. ${ }^{319}$ Christopher Walker has complied an exhaustive literature review of these critiques, ${ }^{320}$ so it is not necessary to do so here in detail.

Combined with the decline of deference at the Court itself, these external critiques make it appear that Chevron has reached a critical moment. Some have speculated that it might be overturned. ${ }^{321}$ For reasons explored in Section $\mathrm{V}$ below, in my view that is unlikely. But open criticism of the doctrine further erodes its power and significance; it exposes publicly what has been true at the Court for at least a decade. Deference is dead.

\section{Effects of Chevron's Decline at Agencies}

Before exploring what the death of deference at the Court means for the future, it's worth briefly exploring what it has meant for agencies so far. To what extent, if any, do agencies still count on deference to their interpretations of statutes?

Some recent opinions suggest they don't count on it at all. $B N S F$ is particularly illustrative: the majority does not cite Chevron or discuss deference, instead simply interpreting the statute in light of past Court precedent; it effectively applies de novo review. ${ }^{322}$ As Justice Gorsuch notes in his dissent, Chevron deference was almost absent from consideration of the case, from briefs through oral argument to the opinion.

In the past, the briefs and oral argument in this case likely would have centered on whether we should defer to the IRS's administrative interpretation ... [but] BNSF devoted scarcely any of its briefing to Chevron. At oral argument, BNSF's lawyer didn't even mention the case until the final seconds - and even then "hate[d] to cite" it. No doubt, BNSF proceeded this way well aware of the mounting criticism of Chevron deference. And no doubt, too, this is all to the good. Instead of throwing up our hands and letting an interested party-the federal government's executive branch, no less-dictate an inferior interpretation of the law that may be more the product of politics than a scrupulous reading of the statute, the Court today buckles down to its job of saying what the law is in light of its text, its context, and our precedent. Though I may disagree with the result the Court

${ }^{317} I d$. (describing Delaware as "a longtime skeptic of deference").

${ }^{318}$ See, e.g., Beermann, supra note 313.

319 See, e.g., Christopher J. Walker, Toward a Context-Specific Chevron Deference, 81 Mo. L. REv. 1095 (2016). See also Adler, supra note 11.

${ }^{320}$ Christopher J. Walker, Attacking Auer and Chevron Deference: A Literature Review, 16 GEO. J. L. \& PuB. POL'Y 103 (2018).

${ }^{321}$ See Valerie C. Brannon \& Jared P Cole, LSB10204, Deference and its Discontents: Will the Supreme Court Overrule Chevron?, CRS LEgAL SIDEBAR (Oct. 11, 2018) (discussing predictions that Chevron will be overturned).

322 BNSF Ry. Co. v. Loos, 139 S. Ct. 893 (2019) (Gorsuch, J., dissenting). 
reaches, my colleagues rightly afford the parties before us an independent judicial interpretation of the law. They deserve no less. ${ }^{323}$

In this sense, $B N S F$ is a post-Chevron case. Chevron's weakness, driven by its descent into muddy indeterminacy, has spilled out into the open. Once the key citation at the core of many administrative law cases, around which the outcome depended, Chevron appears to have become a case litigants "hate to cite." Sometimes the Court may consider deference sua sponte despite no party actually asking for it, but in such cases the agency's refusal to request deference appears to make the Court less willing to grant it. ${ }^{324}$ Such "Chevron waiver," if it becomes regular practice or Court doctrine, creates a deference death spiral. Agencies are less likely to cite Chevron, either because they don't think it will do much good or because it actively repels some Justices, and as a result deference would be waived even if the Court might otherwise have been willing to grant it. ${ }^{325}$

Continued refusal by the Court or parties to cite Chevron in cases where it should doctrinally be relevant will make it much more difficult for to assess future trends in Chevron's significance. The Justices will notice it's absence, of course, as with Justice Kagan's concurrence in Little Sisters of the Poor in which she notes puzzlement at the majority's omission of Chevron in the kind of case that in her view it was "built for." ${ }^{326}$ But casual observers of the Court, or specialists in fields other than administrative law, may not. If litigants do "hate to cite" Chevron, that will create problems for research as well. Salmanowitz and Spamann's work on how often the Court applies Chevron is based on using parties' briefs to determine when Chevron is relevant; they assume that " [i]f neither party argued for Chevron deference, then the case is not plausibly a Chevron case." ${ }^{227}$ That seems like an entirely reasonable assumption, unless parties are refusing to cite Chevron because they fear annoying its opponents on the Court, or think space in briefs is better used on arguments more likely to determine the outcome of the case. Like astronomers in a rapidly expanding universe, we may be living in the last era in which the subject of our study is observable.

Other evidence for agency response to decline in deference at the Court is inconclusive. The largest effect might be hidden: as noted above, a robust Chevron empowers agencies to interpret statutes more boldly; a weakened, narrowed, and muddied Chevron does the

${ }^{323} I d$. at 908-09 (Gorsuch, J., dissenting).

${ }^{324}$ See, e.g., County of Maui, Haw. v. Haw. Wildlife Fund, 140 S. Ct. 1462 (2020) (seeming to deny Chevron deference in part because the Solicitor General had not requested it, though Justice Breyer's discussion of deference is somewhat cryptic). See also Guedes v. Bureau of Alcohol, Tobacco, Firearms, \& Explosives, 140 S. Ct. 789 (2020) (Gorsuch, J., dissenting from denial of certiorari) ("[T]he government expressly waived reliance on Chevron ... [t] his Court has often declined to apply Chevron deference when the government fails to invoke it.").

${ }^{325}$ But see Hickman, supra note 243 (arguing the Court has not adopted Chevron waiver and is not likely to do so).

${ }^{326}$ Little Sisters of the Poor Saints Peter \& Paul Home v. Pennsylvania, 140 S. Ct. 2367, 2397 (2020)

(Kagan, J., concurring in the judgment).

${ }^{327}$ See Salmanowitz \& Spamann, supra note 149 , at 83. 
reverse. Reacting to the decline of deference, agencies might react by interpreting statutes more narrowly, or by not regulating at all in areas of statutory ambiguity. But because we only see the products of rulemaking, not internal deliberations, any decline in agency ambition would be hard or impossible to observe.

In a recent paper, Daniel Hornung describes how wariness about application of the major questions doctrine affected agency deliberations during formulation of the Clean Power Plan (aimed at reducing greenhouse gas emissions from power plants). ${ }^{328}$ Based on this experience, he concludes that expansion of the doctrine (and therefore denial of Chevron deference) will have a negative effect on agencies. ${ }^{329}$ "If the courts continue to rely on the major questions doctrine, the critical role agency lawyers play within these rulemaking processes will deteriorate further, leading to less deliberative processes and statutory interpretation that is less comprehensive." 330 More research on internal agency assumptions about and reactions to declining Chevron deference, potentially including interviews of agency general counsel, would be a valuable research project.

A look at the observable output of agencies - rulemakings - shows some changes in treatment of Chevron over time and across presidential administrations, but no clear trends. On the one hand, citations of Chevron in economically significant rulemakings have clearly and sharply declined in recent years; only five such rulemakings cite Chevron since 2017. ${ }^{331}$ In 2017 and 2018, not a single significant rulemaking cited Chevron; this had not happened since at least 1995.

But a broader view suggests there is no clear trend away from agency appeal to Chevron deference. Considering all rulemakings (not just economically significant ones), citations of Chevron were low in 2017-18 (five citations) but substantially higher in 2019 and 2020. ${ }^{332}$ Even if there is a real decline in the rate at which Chevron is cited in significant rulemakings, that might not be a signal of declining relevance of the doctrine at the Court so much as antipathy toward Chevron specifically or the regulatory state generally among Trump administration leadership. The Trump administration has also issued fewer rulemakings and fewer significant rulemakings than past administrations, so some decline in the raw number of citations to Chevron is to be expected. Indeed the rate of such citations (i.e. the share of rulemakings citing Chevron) has not changed much across presidential administrations since at least the mid-1990s, when searchable Federal Register data becomes available. Nor is there much of a long-term trend, though there is substantial yearto-year fluctuation. (See Figure 1 and Figure 2).

${ }^{328}$ See generally Daniel Hornung, Agency Lawyers' Answers to the Major Questions Doctrine, 37 YALE J. ON REG. 759 (2020).

${ }^{329} I d$. at 762 .

${ }^{330} \mathrm{Id}$.

${ }^{331}$ Data (on file with author) (available in spreadsheet form at https://docs.google.com/spreadsheets/d/ 11wDygZyJ8NQv7BINV5z5k99DEw0pG3Jr07ZE8k4cpGU/edit?usp=sharing). Data was obtained via a search of final rules in the Federal Register citing Chevron (435 U.S. 837). This search is likely to be slightly overinclusive, to the extent it includes any rulemakings citing Chevron for substantive Clean Air Act precedent, rather than as a deference doctrine. The Federal Register has data searchable back to 1994; 1995 is the first full year included.

${ }^{332}$ During 2020, the twenty-two citations are the highest in any year back to at least 1995. 
Figure 1

Rate of Chevron Citations

$$
\text { - All Rules - Economically Significant Rules }
$$

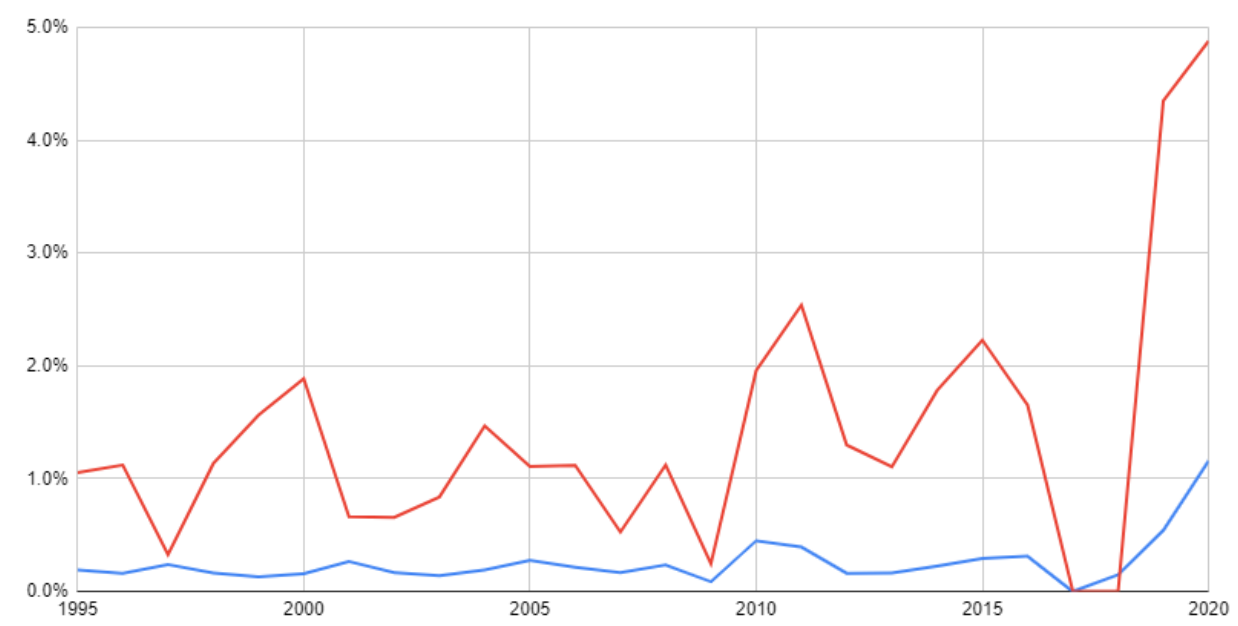

Figure 2

Rate of Chevron Citations by Presidential Administration

All Rules Economically Significant Rules

$2.0 \%$

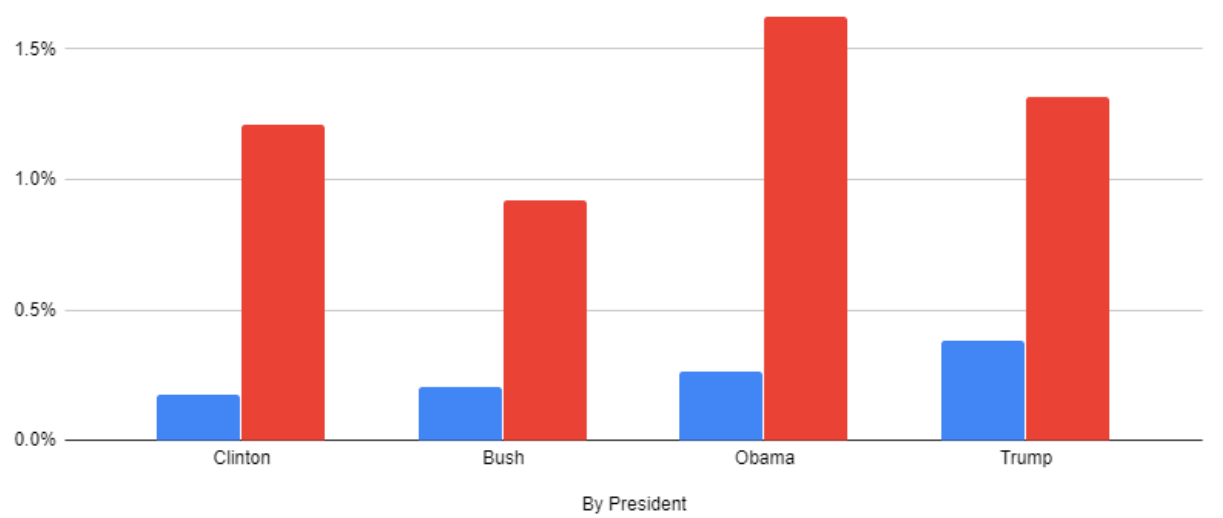

If agency citations to Chevron in rulemakings had appreciably declined, that would have been additional evidence that its predictive power and doctrinal influence had declined 
(though the anti-regulatory sentiment of the Trump administration would be a plausible alternative cause). Indeed one might not expect to see any drop in agency citations until quite recently, despite the long-term decline in Chevron's influence at the Court. It's possible that Chevron's weakness did not become clear until high-profile losses by the Obama administration at the Supreme Court in Chevron cases like Michigan, and victories despite denial of deference in others like King. It is also possible that President Obama's ambitious regulatory agenda in the face of a recalcitrant Congress in most of his time in office required agencies to continue to rely on Chevron deference even as they became aware that it was not much help.

Another reason agency citations to Chevron might not decline even as deference has declined at the Supreme Court is that, as Barnett and Walker have found, ${ }^{333}$ Chevron retains influence in the lower courts. Not all agency rules are challenged in court, and when they are those challenges are usually resolved in the lower courts. To the extent rulemakings are speaking to courts on matters of statutory interpretation, they are primarily defending against challenges there, at least outside of the highest-profile actions that agencies may assume will eventually reach the Supreme Court. Or perhaps agencies are just going through the motions, citing Chevron more out of habit than hope.

An alternative measure of agency reliance on Chevron might be found in the frequency of Chevron citations in their briefs, or those of the Solicitor General, in cases before the Court. As discussed above, there are at least a few recent cases in which the agency or SG do not advance Chevron deference arguments, and one case, County of Maui, in which Justice Breyer raised the issue sua sponte. ${ }^{334}$ Extracting evidence of a trend from agency briefs is likely to be difficult, however. First, as the debate between Eskridge \& Baer and Salmanowitz \& Spamann illustrates, it's hard to identify the universe of cases in which Chevron deference is applicable (i.e. the denominator). Salmanowitz \& Spamann's method for escaping this meta-interpretive quagmire, reference to the agency and SG briefs, is of no use if the briefs themselves are the subject of inquiry. Second, the reasons for agency refusal to cite Chevron might also be tied up with the specific facts of the case; for example, an agency might change its position, muddying the deference inquiry. And finally there just aren't that many Supreme Court statutory interpretation cases. Any evidence uncovered from briefs would have to come with substantial caveats about sample size bias.

It may be, therefore, that there is an evidentiary gap. The large number of rulemakings makes for a robust data set, but it isn't very useful for observing effects of changes in deference at the Court because those rulemakings are only secondarily or tertially (if at all) concerned with Supreme Court litigation. Briefs in Supreme Court cases are obviously only concerned with appealing to the Court, but there may not be enough of them to draw any conclusions, though as noted above reluctance to cite Chevron makes identifying the universe of briefs to examine difficult. Nevertheless, exploration of briefs in recent cases is likely a valuable qualitative research project.

\footnotetext{
${ }^{333}$ See Barnett \& Walker, supra note 14.

${ }^{334}$ See County of Maui, supra note 243.
} 
Whether or not agencies continue to rely on Chevron deference in their internal planning, if they expect an interpretive question to reach the Supreme Court, they shouldn't rely on it. Seeking deference at the Court as an agency increasingly resembles a cruelly designed game: deference is supposedly available, but the list of exceptions, carve-outs, and interpretive canons, some explicit and some unstated, is so mind-numbingly extensive and vague that in practice meaningful deference is unavailable. I am increasingly sympathetic to administrative law students who learn "official" Chevron and its two steps, spend weeks learning various exceptions and reading cases that set inconsistent boundaries, and then decide they can do little but throw up their hands and go through the motions on the exam. Agency lawyers who think their interpretations are likely to reach the Court likely feel the same way. This is no mere technical change. It substantially constrains the power of the executive branch, just as Chevron expanded it. ${ }^{335}$

\section{E. Why?}

Why is Chevron under such attack, and why has deference declined so much at the Court? Three factors seem most important.

\section{Anti-Administrativism}

First, the decline of deference is part of a wider rhetorical and ideological antiadministrative shift on the Court. In Gillian Metzger's view, this trend has become sufficiently ascendant that the administrative state can be described as "under siege," with battles over the scope of administrative power thought resolved in the New Deal era now being refought. ${ }^{336}$ For many critics of Chevron (and architects of its decline), the reduction in agency power is the point. Justice Thomas' and Gorsuch's calls for Chevron to be reconsidered are explicitly motivated by concern over agency authority. ${ }^{337}$ Justice Kavanaugh's call for it to be reformed and constrained is driven by similar institutional concerns. ${ }^{338}$

${ }^{335}$ See generally Linda D. Jellum, The Impact of the Rise and Fall of Chevron on the Executive's Power to Make and Interpret Law, 44 LOY. U. CHI. L.J. 141 (2012).

${ }^{336}$ See generally Gillian E. Metzger, Foreword: 1930s Redux: The Administrative State Under Siege, 131 HARV. L. REV. 1 (2017).

${ }^{337}$ See, e.g., Michigan v. EPA, 576 U.S. 743, 763 (2015) (Thomas, J., concurring) ("Should EPA wield its vast powers over electric utilities to protect public health? A pristine environment? Economic security? ... [W] e should be alarmed that it felt sufficiently emboldened by those precedents to make the bid for deference that it did here."); see also Gutierrez-Brizuela v. Lynch, 834 F.3d 1142, 1149 (10th Cir. 2016) (Gorsuch, J., concurring) ("Chevron and Brand $X$ permit executive bureaucracies to swallow huge amounts of core judicial and legislative power and concentrate federal power ....").

${ }^{338}$ See Kavanaugh, supra note 32, at 2151 ("We must recognize how much Chevron invites an extremely aggressive executive branch philosophy of pushing the legal envelope."). 
Chevron itself was a deregulatory decision, ${ }^{339}$ but in shifting power from courts to agencies Chevron allowed future administrations more regulatory freedom. After Brown $\mathcal{E}$ Williamson and its progeny, agencies are on notice that assertions of new authority will be met with skepticism at best and outright hostility at worst from the Court. The suggestion that an agency today might receive deference for a similarly bold statutory reinterpretation seems laughably quaint. ${ }^{340}$ The resulting expansion/revival of the major questions doctrine is aimed directly at constraining perceived excesses of agency power. The relative absence of any parallel decline in deference in the lower courts might have similar roots: cases that reach the Court are more likely to involve broad or significant agency assertions of authority that alarm anti-administrativists, making them particularly unlikely to defer to agency interpretations (and making deference arguments advanced by other Justices less likely to attract their votes).

This puts deference's decline within a larger ideological project. As Cass Sunstein notes, "The current struggle over Chevron might well be seen a proxy war in a larger battle over the legitimacy of the administrative state, or perhaps as a significant skirmish in that battle." ${ }^{341}$ Attacking Chevron may not even be the most important part of the antiadministrative project; the Court's moves toward a revived nondelegation doctrine ${ }^{342}$ and, perhaps, more robust hard-look review under the $\mathrm{APA}^{343}$ might do more in the long run to constrain agencies. The track record of agencies in federal courts in recent years has been extremely poor, ${ }^{344}$ though that is usually attributed more to the Trump administration's pairing of norm-breaking policy with a careless approach to administrative details. ${ }^{345}$

${ }^{339}$ See Metzger, supra note 336, at 15 ("If anything, the Reagan era sowed the seeds for what conservatives today view as executive overreach. It was the Reagan Administration's deregulatory efforts that produced the Chevron doctrine and deference to an agency's reasonable interpretation of ambiguous statutes that it implements.").

340 To be clear, by "bold" I mean an assertion of broad new authority, not interpretive creativity. The FDA's interpretation was a straightforward application of statutory text, however big the regulatory change it would have wrought.

${ }^{341}$ Sunstein, supra note 312 , at 1618.

${ }^{342}$ See Gundy v. United States, 139 S. Ct. 2116, 2131 (2019) (Gorsuch, J., dissenting). In his Gundy dissent, Justice Gorsuch calls for a reinvigoration of the nondelegation doctrine. He is joined by Justice Thomas and Chief Justice Roberts, while Justice Alito writes separately but expresses sympathy for their views. See id. at 2130 (Alito, J., concurring in the judgment). Justice Kavanaugh took no part in Gundy but later indicated support for Justice Gorsuch's position in his dissent from denial of certiorari in Paul v. United States, 140 S. Ct. 342 (2019). This indicates there are five votes on the court for a revived nondelegation doctrine, though we will likely soon see whether these five have the courage to pull that trigger when they are in the majority, and what form a revived doctrine would take.

${ }^{343}$ See, e.g., Dep't of Com. v. New York, 139 S. Ct. 2551 (2019) (rejecting an agency rulemaking on the grounds its stated rationale was pretextual).

${ }^{344}$ See Roundup: Trump-Era Agency Policy in the Courts, InST. FOR POL'Y INTEGRITY (July 27, 2020), https://policyintegrity.org/trump-court-roundup (tracking success rate in administrative law cases; at the time of this writing the administration had lost almost $90 \%$ of such cases [98/110]).

${ }^{345}$ See, e.g., Fred Barbash \& Deanna Paul, The Real Reason the Trump Administration Is Constantly Losing in Court, WASH. POST (Mar. 19, 2019), https://www.washingtonpost.com/world/national-security/the-real- 
It is noteworthy that opposition to Chevron deference on the Court appears to have survived intact during a deregulatory presidential administration. ${ }^{346}$ Deference to agencies under deregulatory leadership leads to less regulation, though it does still shift power to agencies relative to the courts. This suggests that views on Chevron have hardened. Until and unless a change of heart or personnel on the Court halts its anti-administrative turn, deference to agency interpretations will remain rare.

\section{Textualism}

Another possible cause of deference's decline is the parallel rise of textualism to become the dominant mode of statutory interpretation, led by Justice Scalia. The battles over interpretive methodology that paralleled Chevron's rise and fall ${ }^{137}$ are (for now) largely over. As Justice Kagan famously remarked, "we are all textualists now." 348 At first glance this jurisprudential trend seems unrelated: Chevron's innovation was to require deference when there is statutory ambiguity, regardless of which of the "traditional tools of statutory interpretation" (whether text only, text plus context, or a big toolbox) are used to establish whether ambiguity exists. But restricting the range of interpretive tools (textualism's essential project) means less ambiguity. That may seem paradoxical; shouldn't bringing more tools to bear on interpreting a statute allow more interpretive work to be done, resolving more ambiguity? In practice, no; because different sources of statutory meaning (text, context, purpose, legislative history, etc.) may point in different directions, a smaller set of tools will often produce greater certainty, not less.

Textualist analysis may also led itself rhetorically to more conclusive claims of statutory meaning. If judges must consider multiple, sometimes contradictory, lines of evidence their written opinions must then balance those often-conflicting sources to reach a conclusion about a statute's best meaning. Purely textualist analysis is perhaps more likely to result in a single definitive statement about the statute's meaning. This is somewhat of

reason-president-trump-is-constantly-losing-in-court/2019/03/19/f5ffb056-33a8-11e9-af5b-

b51b7ff322e9_story.html ("[T]he rulings so far paint a remarkable portrait of a government rushing to implement far-reaching changes in policy without regard for long-standing rules against arbitrary and capricious behavior.").

${ }^{346}$ Cf. Adrian Vermeule, Two Futures for Administrative Law, YALE J. On REg. NoticE \& COMmEnT (Nov. 30, 2016), https://www.yalejreg.com/nc/two-futures-for-administrative-law-by-adrian-vermeule/ (predicting either "a new coalition between liberal lawyers and conservative lawyers in the courts, both deciding - for different reasons - that the administrative law of the Obama era is too favorable to presidential administration" or "a bewildering switch of places" between conservative and liberal lawyers' views on administrative law questions "but no major change in legal doctrine." Neither prediction seems to have been entirely borne out; conservatives on the Court and outside government have remained skeptical of administrative authority generally and Chevron specifically, even if their views on executive power more broadly have shifted, and vice versa for liberals). See also Sunstein, supra note 312, at 1619 ("With respect to Chevron, the right and the left have switched sides.").

${ }^{347}$ See generally Jellum, supra note 9.

${ }^{348}$ See The Antonin Scalia Lecture Series: A Dialogue with Justice Elena Kagan on the Reading of Statutes, YouTuBE (Harvard Law School, Nov. 25, 2015), https://www.youtube.com/watch?v=dpEtszFToTg. 
an oversimplification; even committed textualists acknowledge that multiple lines of evidence of meaning are available within textualism, including context and, perhaps, statements of statutory purpose. ${ }^{349}$ Linda Jellum identified the relationship between textualism's rise and Chevron's decline significantly earlier, writing in 2006 that "[a]s the Court embraced a textualist Chevron, it simultaneously adopted a more intentional pre-step (step zero) and limited Chevron's application." 350

In any case, the result on a textualist-dominant Court is that much or all of the statutory interpretation action happens in Chevron Step One, as the cases discussed above illustrate. In the last five terms, 9 or 10 of the 15 Chevron cases have been resolved by finding a definitive interpretation of the statute, making the agency's reading (and any deference due to it) irrelevant.

Textualism may not have this effect on deference forever. Textualism seems to be on the way to losing whatever political valence it may have once had, as Justice Gorsuch's textualist approach in extending the protection of Title VII of the Civil Rights Act to sexual orientation in Bostock v. Clayton County illustrates. ${ }^{351}$ To use Carol Rose's metaphor again, once-crystalline textualism has, perhaps inevitably, been muddied as it has become dominant. It is even possible that Chevron's muddying is merely an epiphenomenon of a larger contemporaneous jurisprudential crystallization (which appears to have now peaked and begun its own muddying). I am no legal philosopher, however, and won't speculate any further than that.

\section{Inherent Instability}

Finally, the seeds of Chevron's decline may have been within it the whole time. Carol Rose's core insight embodied in the crystals and mud framework is that crystalline rules are inherently unstable. ${ }^{352}$ Their muddying over time is normal, expected, and perhaps inevitable. Chevron seems particularly vulnerable to muddying. As noted above, it is a judge-made doctrine that reduces judicial power, and requires judges to accept statutory interpretations that they view as suboptimal. Judges will inevitably chafe under its restrictions. Justice Breyer noted this source of instability in 1986, just two years after Chevron was decided. ${ }^{353}$

${ }^{349}$ See Scalia, supra note 19, at 515. See also Util. Air Reg. Grp. (UARG) v. EPA, 573 U.S. 302, 316-19 (2014) (adopting different operative definitions of the same text in the same statute depending on context).

${ }^{350}$ See Jellum, supra note 9, at 781.

${ }^{351}$ See Bostock v. Clayton Cnty., Ga., 140 S. Ct. 1731, 1737 (2020) ("When the express terms of a statute give us one answer and extratextual considerations suggest another, it's no contest. Only the written word is the law, and all persons are entitled to its benefit.").

${ }^{352}$ See Rose, supra note 15, at 595.

353 See Breyer, supra note 22, at 379 (" [N]either a strict view of Chevron, nor any other strictly defined verbal review formula requiring deference to an agency's interpretation of law can prove successful in the long run [because] such a formula asks judges to develop a cast of mind that often is psychologically difficult to maintain. It is difficult, after having examined a legal question in depth with the object of deciding it correctly, 
Viewed in isolation, the Court's move away from Chevron's initial clarity is radical, even if gradual. But perhaps it should not be so surprising. Chevron is almost as old to us today as the Administrative Procedure Act was when Chevron was decided. Chevron had a good run. And its muddying decline was probably baked in from the beginning. As Rose suggests, the evolution from crystals to mud and back is cyclical, with the seeds of each change planted in the previous one.

That cyclical story matches Chevron's rise and fall. The imprecision and unpredictability of Skidmore-era deference decisions cried out for a clarifying rule, which Chevron supplied (or was drafted into). Perhaps inevitably, the "rule" soon came under attack for its failure to account for circumstance. Early on, it was claimed that deferring to agency interpretations of criminal statutes violates important norms, including the rule of lenity. Then it was claimed that deference shouldn't allow agencies to make sweeping changes to major areas of policy (Brown \& Williamson). And surely deference shouldn't be available for small-potatoes agency decisions without much process (Mead). Perhaps each of these (and the myriad other exceptions to Chevron) can be defended on their own merits, but the trend is clear and the result is a muddied doctrine that has lost whatever power it once had.

Implicit erosions of Chevron have followed a similar pattern. Judges over time created more and more discretionary authority within the threshold ambiguity inquiry (Step One), and unsurprisingly the outcomes usually tracked judges' preferences. The major question exception is an initially implicit restriction on Chevron that over time became explicit. Indeed the seeds of Chevron's internal, implicit erosion were embedded from the beginning. By giving judges the power to decide in Step One which cases were within Chevron's zone of deference, the doctrine gave them the power to chip away at the crystal. In essence, Chevron locked judges into a cell, but handed them the keys. As noted above, there was probably no alternative, at least absent Congressional action. But because of this internal contradiction, a permanently crystalline range of Chevron deference was never plausible.

In an earlier paper, I argued that this tension meant that the major questions doctrine should be valued by defenders of agency authority, not criticized as it typically is. ${ }^{354}$ Because judges will find it particularly difficult to defer to agency statutory interpretations in highprofile and high-stakes major questions cases, separating them from the mainline of Chevron jurisprudence avoids setting precedent that undercuts deference more generally (e.g. continued expansion of judges' power at Step One, Brown \& Williamson-style). ${ }^{355}$ In light of the general decline in deference at the Court documented here, I'm no longer convinced that view on the major questions doctrine is correct. Not because the Court is relying too frequently on the major questions doctrine-it remains rarely cited, at least explicitly (though adoption of Justice Kavanaugh's "major rules" version would change

to believe both that the agency's interpretation is legally wrong, and that its interpretation is reasonable. More often one concludes that there is a 'better' view of the statute for example, and that the 'better' view is 'correct,' and the alternative view is 'erroneous.' ").

${ }^{354}$ See generally Richardson, supra note 131.

${ }^{355} \mathrm{Id}$. at $409-27$. 
that). Instead, there just isn't much mainline Chevron deference to protect, at least at the Supreme Court. In the lower courts, where meaningful deference persists, the major questions doctrine has never much been applied; it is largely a Supreme Court-only doctrine. ${ }^{356}$

Alternatively, it is possible to view Chevron's instability not as an independent cause of its decline, but as the means by which other forces (e.g. anti-administrativism and the rise of textualism) were able to bring about that decline. Crystals don't just become mud on their own, they yield to external pressure brought to bear on their inherent contradictions. Under this view, Chevron's inherent instability is the most important factor in its decline but not the primary cause.

\section{CHEVRON'S FUTURE}

If Chevron has lost most of its influence and power, and is under open attack from multiple justices, one might conclude that it is likely to be overruled. Many scholars and observers have done so. ${ }^{357} \mathrm{~A}$ weak Chevron seems vulnerable to a killing blow, and critics may smell blood in the water. Justices Thomas and Gorsuch appear ready to reject Chevron today. Justices Alito and Kavanaugh have shown some similar inclinations, though their views are less clear. Chief Justice Roberts dissent in City of Arlington shows deep concern with Chevron in some circumstances, though it stops well short of indicating an appetite to overrule it. Nevertheless it's not hard to count to five votes here.

\section{A. Rejection?}

I don't think the Court is likely to overrule Chevron any time soon, however. The Supreme Court does not overrule cases lightly, and is particularly unlikely to overrule a precedent with the name recognition and perceived importance of Chevron. But stare decisis protects the name of precedent more than its content. The principle has not protected Chevron from the erosion discussed above. This is not an unfamiliar pattern - the Court frequently limits the scope of precedent without overruling it; in the extreme a case may be "limited to its facts" (i.e. overruled in all but name). As one scholar describes a doctrinal shift in the opposite direction (from mud to crystal) in another area of law:

Given the Supreme Court's adherence to the minimum contacts language for seventy years now, it seems unlikely that the vocabulary will soon change. The question rather is whether the vocabulary will continue to be a cloak to hide jurisdictional doctrine that is in truth no less rigid than that of the nineteenth and early twentieth century. The minimum contacts

${ }^{356}$ Kavanaugh's "major rules" statement in U.S. Telecom Ass'n v. FCC, 855 F.3d 381, 420 (2017), is notable exception, but is in dissent of denial of en banc review, not merits opinion. The doctrine is rarely invoked, but this is not to suggest that it never is. See Hornung, supra note 328, at 762 (identifying nine invocations of the doctrine in the lower courts since $U A R G$ in 2014).

${ }^{357}$ See Brannon \& Cole, supra note 321 (summarizing and referencing a wide variety of predictions of Chevron's demise). See also Sunstein, supra note 312, at 1617. 
test is in its twilight because it has become almost completely separated from the fairness rationale that underlay the test as it was originally conceived. So while the minimum contacts language will almost certainly persist, the test as a meaningful exposition of the Due Process Clause may not live to see the next dawn, if indeed it is still alive at all. ${ }^{358}$

I predict this is where Chevron is headed; as litigants and Justices themselves recognize the decline in Chevron's power and influence, it will likely play a smaller role in briefs, oral arguments, and opinions.

To illustrate the same point in the opposite direction, it's widely believed that applying Chevron deference substantially constrains judges' role in a case. Then-judge Gorsuch argues as much in his Gutierrez-Brizuela concurrence:

Chevron seems no less than a judge-made doctrine for the abdication of the judicial duty. Of course, some role remains for judges even under Chevron. At Chevron step one, judges decide whether the statute is "ambiguous," and at step two they decide whether the agency's view is "reasonable." But where in all this does a court interpret the law and say what it is? When does a court independently decide what the statute means and whether it has or has not vested a legal right in a person? Where Chevron applies that job seems to have gone extinct. ${ }^{359}$

This is a good description of the textbook understanding of Chevron, and was perhaps how it worked in practice in the 1990s (at least outside the "major questions" line of cases and other early excisions, like criminal cases). But the ever-growing list of judge-made exceptions to Chevron and dramatic expansion in judicial power at Step One, detailed above, make it a wildly inaccurate characterization of Chevron as applied at the Court today. It serves Gorsuch's rhetorical purposes to characterize Chevron as shackling judges, but it has not meaningfully done so in a long time at the Supreme Court, at least since Brown $\mathcal{E}$ Williamson, and in some areas of law (e.g. criminal) far longer than that. As the Court's Chevron cases decided in the last few years illustrate, justices have ample power to control the flow of a Chevron case through the two (or three) step framework and reach any outcome a majority support.

This increase in judges' power and flexibility under Chevron (and the corresponding reduction in power and predictability for agencies) makes formal rejection of the doctrine less likely, not more. Why spend the time, effort, and/or political capital to formally overrule a decision that has little impact today? ${ }^{360}$ If the goal of Chevron's critics is to shift interpretive authority from agencies (back) to courts, that has largely been achieved already, at least at the Supreme Court level. To tie Chevron's future to the reasons for its decline discussed in the previous Section, the anti-administrativists need not overturn it if

\footnotetext{
${ }^{358}$ Patrick J. Borchers, The Twilight of the Minimum Contacts Test, 11 Seton Hall Cir. Rev. 1, 4 (2014).

${ }^{359}$ Gutierrez-Brizuela v. Lynch, 834 F.3d 1142, 1152 (10th Cir. 2016) (Gorsuch, J., concurring).

${ }^{360}$ I have made a similar prediction for similar reasons that Massachusetts $v$. EPA will not be overturned, despite criticism. See Nathan Richardson, The Rise and Fall of Clean Air Act Climate Policy, 10 Mich. J. ENVTL. \& ADMIN. L. (forthcoming 2020), https://osf.io/preprints/socarxiv/wqy93/.
} 
it no longer meaningfully empowers agencies, textualists need not overturn it as they've already won their fight, and the doctrine's inherent instability has declined as it has declined in influence and been muddied, riddled with exceptions. To the extent that work remains to be done, there is no evidence that it cannot be accomplished via the same methods that have eroded Chevron deference already. It is easy to imagine a future for Chevron in which it persists, but continues to shrink in significance.

\section{B. Continued Decline}

If Chevron is not overturned explicitly, then what? Predictions are, of course, dangerous and usually wrong. But having made one already (that Chevron) will not be overruled anytime soon, I am emboldened to speculate. Broadly speaking, implicit and explicit erosion of Chevron is likely to continue. The trend for the foreseeable future is most likely more mud, not crystal.

One possibility is that it fades away silently. Chevron will be given lip service at best. Some justices will cite Chevron less often; when they do, it will be with some reluctance, to buttress an opinion in which the agency wins a close case. Other justices will not cite Chevron at all in their majority opinions, a practice some on the Court appear to have already adopted: Little Sisters from the 2020 term, discussed briefly above, is a good illustration of what might become the norm. ${ }^{361}$ Justice Thomas, fiery in his criticism of Chevron when writing separately, doesn't mention it at all in his majority opinion. ${ }^{362} \mathrm{He}$ doesn't just pull the punch, he refuses to fight at all. This is no cowardice. Chevron just isn't that important. One can imagine a future in which fewer opinions even bother to cite Chevron and go through the process of siting their statutory analysis within its Step One. Instead, their authors will just do the analysis and move on. Chevron's defenders, like Justice Kagan, will presumably continue to cite it and purport to apply the framework, but will rarely if ever be able to command a majority for opinions in which deference is outcome-determinative. When not outcome-determinative, citation of Chevron will prompt the by-now standard outrage from its critics in dissent or separate concurrence. But that need never mature into critique (much less rejection) in a majority opinion. Decades of battle over the scope and impact of Chevron will have been reduced to theater.

Another possibility is that explicit doctrinal change does happen, but by continuing erosion of Chevron at the margins, rather than by overturning it. This could come in a variety of explicit forms. For example, Chief Justice Roberts' dissent in City of Arlington advocating a Chevron exception for "jurisdictional" interpretive questions might become the majority position in a future case without Justice Scalia on the Court to hold the line. ${ }^{363}$ Or the form of agencies' Chevron arguments might be constrained, e.g. by forcing them to adopt a single interpretation of statutory text, rather than arguing in the alternative that it

\footnotetext{
${ }^{361}$ Little Sisters of the Poor Saints Peter \& Paul Home v. Pennsylvania, 140 S. Ct. 2367 (2020).

${ }^{362} \mathrm{Id}$.

${ }^{363}$ See also Adler, supra note 11, at 993 (calling for City of Arlington to be rejected).
} 
is either clearly in their favor or ambiguous but within the scope of deference. The Court could also state clearly that Chevron deference is only available to "procedurally complete" agency decisions, such as notice-and-comment rulemaking and formal adjudication (this has, after Mead, been strongly implied but not formally required). The Court could also overturn NCTA v. Brand $X$ insofar as that case allows agencies to overrule judicial interpretations of statutes, as that decision's author, Justice Thomas, has recently called for. ${ }^{364}$

Alternatively, Chevron's decline might continue silently. The Court might just further expand the scope of existing exceptions to Chevron. The "major questions" doctrine could grow as future cases steadily create precedent increasing its scope-it's relatively easy to argue the doctrine should be applied to a case that is only slightly less "major" than the previous lower bound, especially because the criteria that make a case "major" are never defined. Or the Court could be even more aggressive that it has already become at ferreting out statutory meaning, leaving no cases of statutory ambiguity in which agencies get interpretive deference. As Justice Scalia pointed out more than 30 years ago, Chevron is irrelevant if it only applies when interpretive questions are in true equipoise as that never happens in practice. ${ }^{365}$ Justice Kavanaugh's claim that he is willing to decide cases at Step One when he is only "60/40" certain of a statute's meaning points in this direction. It is easy to imagine a future in which Chevron deference remains nominally available but is never granted in practice because every case can be disposed of at Step Zero or Step One. I doesn't matter much if a dish is on a restaurant menu if the kitchen is closed, or always out of a necessary ingredient.

In short, the long process of Chevron's muddying could continue; however weak Chevron is now, the number of potential explicit exclusions and incremental moves to broaden Step One is infinite. Eventually, supreme Court doctrine in agency statutory interpretation cases may become indistinguishable from Skidmore's multifactor deference "test." This is not to say an imperial Court will ignore agencies entirely; agencies will still get "deference" in that their arguments are (sometimes) taken more seriously than those of other litigants, but there will no longer be a deference rule. Crystals to mud.

\section{Holding the Line}

A final possibility, suggested by Cass Sunstein, is that a Chevron could be recrystallized, but with an explicitly narrower scope; as he puts it, Chevron could be "domesticated." "366 Judicial primacy in determining whether statutory ambiguity exists (i.e. Step One) could be clarified (including a more sharply defined major questions doctrine), the menu of interpretive canons could be clearly established, and the scope of deference

\footnotetext{
${ }^{364}$ See Baldwin v. United States, 140 S. Ct. 690 (2020) (Thomas, J., dissenting from denial of certiorari).

${ }^{365}$ See Scalia, supra note 19, at 520.

${ }^{366}$ See Sunstein, supra note 312, at 1668.
} 
available at Step Two more clearly defined. ${ }^{367}$ This domestication could come in a Supreme Court opinion or, conceivably, from Congress. ${ }^{368}$

The Court has already taken a very similar approach in constraining and crystallizing the related Auer/Seminole Rock doctrine regarding deference to agency interpretations of their own regulations. In Kisor v. Wilkie, Justice Kagan announced a five-factor test for when deference would be available. ${ }^{369}$ But these factors are not really new, ${ }^{370}$ and are quite similar to Sunstein's suggestions for Chevron. Deference is only available where judges determine the regulation at issue is "generally ambiguous" after applying "traditional tools of statutory interpretation." The agency's interpretation must also be "reasonable", reflect the agency's "authoritative position" and "fair and considered judgment", and lie within its "substantive expertise." 371 All of these factors have Chevron parallels: Step One, Step Two, the Mead exception, the "stay in your lane" principle, and the exception for mere litigating positions. Kisor clarifies that these apply in the context of agency interpretations of regulations while collecting and systematizing them. Kisor also suggests (though does not say) that its list of factors is complete; if a reason not to grant deference cannot be found in the five-factor test, deference applies (though of course the Court could add to the list later). In this sense, it is a (re)crystallization of Auer deference.

Could the same be done for Chevron? Maybe. On one hand, it's less necessary; as noted, all of Kisor's factors already exist in the Chevron context. One view of Kisor is that all it really did was to clarify that Chevron's steps, exceptions, and limitations applied to Auer deference too. Doing the same for deference to agency interpretations of statutes would just be a restatement, not a recrystallization. On the other hand, many observers believed Auer would be overturned in Kisor. The fact that it was not is probably due to Justice Kagan's efforts in producing a robust list of exclusions and limitations sufficient to satisfy at least some of the Justices with objections to the doctrine. A similar process might save Chevron and even, to the extent that it recrystallizes the doctrine, forestall further erosion. That certainly seems to be the thrust of Sunstein's proposal.

But even if that comes to pass, it's worth asking whether the rump Chevron deference that it would preserve would really be deference at all. No deference was available in Kisor because multiple factors took the case outside of the scope of deference. It is possible that few if any future cases involving agency interpretations of regulations will survive application of the Kisor factors. Auer may be dead in all but name, Kisor having killed it in a failed attempt to save it. The same could happen with a Kisor-style restatement/recrystallization for Chevron, but in that case it's not necessary to speculate whether much would be left of deference. We can already observe from the Court's Chevron cases that there is little or no deference available anymore. At best, a restatement could only slow the decline, not restore any lost deferential power (or, as seems to have

${ }^{367} \mathrm{Id}$. at $1672-78$.

${ }^{368} I d$. at 1678 .

${ }^{369}$ Kisor v. Wilkie, 139 S. Ct. 2400, 2415-18 (2019).

${ }^{370}$ More precisely, they may be new in the Auer context, but all already existed in the Chevron context.

${ }^{371}$ Kisor, 139 S. Ct. at 2415-18. 
happened in Kisor, forestall a skeptical Court from overturning it). It is, at best, a defensive approach.

One other possible future for Chevron, suggested by Aaron-Andrew P. Bruhl, ${ }^{372}$ is for it to become a lower courts-only doctrine. Deference would be available in the federal district and appellate courts, but not at the Supreme Court. This would de facto overrule Chevron at the Supreme Court level, and is perhaps the most radical shift in the doctrine short of tossing it entirely. This approach has some virtues: it acknowledges and accepts the current, sharp divergence between the level of deference available at the Supreme Court and in lower courts. In doing so it removes a source of doctrinal tension: Supreme Court cases denying deference to agencies no longer risk confusing the lower courts or unintentionally muddying Chevron doctrine there. In my view such a "hierarchically variable" Chevron is unlikely. It probably would not satisfy either Chevron's proponents or its critics on the Court. In particular, Justices Gorsuch and Kavanaugh are unlikely to forget their recent and documented frustration with deference as appellate judges and condemn their erstwhile colleagues to defer to agency interpretations that they would not. It would also increase the Court's workload by creating a class of cases that only it can properly resolve (though overturning Chevron completely would probably increase that workload even more, as the Court would face interminable statutory interpretation circuit splits). But Bruhl's suggestion cannot be ruled out. It may even be the best available description of the status quo.

In short, there are many possible futures for Chevron deference, but of these overturning it seems the least likely, despite being the most-discussed.

\section{The Longer Term}

This is not to suggest that criticism of Chevron will necessarily abate, both within and outside the Court. It may: if $B N S F$ becomes the model and Chevron is frequently ignored, then there will be little need to critique it. If the Court continues to at least play lip service to Chevron, going through the two-step motions, then dissenting (or even concurring) justices and outside critics may of course blame Chevron and continue to call for its rejection. But only if the majority actually grants deference will these critiques have any weight. Recent cases suggest the Court will rarely grant such deference any more (though sample size is small), and this seems unlikely to change. Until and unless it does, criticism of Chevron will at least not increase in volume.

As noted above, Chevron deference continues to play a meaningful role at the district court level. ${ }^{373}$ But decline of the doctrine at the Supreme Court may eventually lead to decline in the lower courts too. Explicit exclusions of classes of cases from Chevron's scope are and will continue to be followed by lower courts. Implicit weakening of Chevron,

372 See generally Aaron-Andrew P. Bruhl, Hierarchically Variable Deference to Agency Interpretations, 89 NoTRE DAME L. REV. 727 (2013).

${ }^{373}$ See Barnett \& Walker, supra note 14. 
primarily via liberal interpretation of Step One, will likely continue to create room for lower courts to reject agency views in favor of their own preferred readings of statutes.

Carol Rose's framework is cyclical; it strongly suggests recrystallization will happen eventually. Overturning Chevron would in one sense further muddy the doctrine: agency statutory interpretation cases would become (slightly) less predictable under a de novo or revived Skidmore standard. But it would be a meta- or second-order recrystallization, in that it would at least clarify the Court's deference doctrine, if not the results. The same can be said for other future paths for Chevron that explicitly reduce its scope (e.g. overruling Brand $X)$, summarize and restate existing exclusions and limitations, Kisor-style, or limit it to lower courts. Each would add doctrinal but not interpretive clarity.

Even if these predictions are right, they are unlikely to persist forever. Over the longer term, as political and policy trends shift, and particularly as the makeup of the Court changes, a revival of deference to agency interpretations is plausible. Administrative law has never been stable for long. The same desire for clarity and predictability that drove Chevron's adoption ${ }^{374}$ might again motivate a deference rule in agency statutory interpretation cases. A change in the ideological balance of the Court would certainly render any predictions made today almost useless. One or both parties might change their position on deference again, or pressing policy issues like climate change might make stronger administrative government necessary, or at least raise its status with elites enough to shift views on the Court. A new deference doctrine might replace Chevron as Chevron replaced Skidmore (intentionally or unintentionally).

Alternatively, Congress could act at any time, in either direction. Chevron is based on, at least allegedly, an implied delegation of interpretive authority by Congress to agencies. Congress could at any point make this delegation explicit-generally, in some range of cases, or only for a specific statute or statutes.

I make no predictions here about when or how a doctrinal recrystallization might happen. Muddy legal doctrine can last a long time - witness the long persistence of many of the Court's multifactor tests. ${ }^{375}$ But Carol Rose's historical analysis suggests neither crystals nor mud last forever.

\section{CONCLUSIONS}

Though it may not have been intended to do so, Chevron rapidly (though never completely) crystallized the degree of deference to agency interpretations of statutes in federal law. Across a wide range of cases and similarly wide range of possible statutory interpretations, agencies and judges had a clear mandate, and a two-step roadmap for getting there. Relative to the Skidmore test that preceded it, Chevron crystallized deference doctrine, and in doing so shifted power from judges to agencies.

\footnotetext{
${ }^{374}$ Or, more precisely, drove the Court to apply Chevron in rule-like fashion, whether that was Justice Stevens' intent or not. A future recrystallization may similarly not be immediately obvious when it happens.

${ }^{375}$ See, e.g., Penn. Cent. Transp. Co. v. City of New York, 438 U.S. 104 (1978) (adopting multifactor test for determining whether regulatory action is a compensable taking within the scope of the Fifth Amendment).
} 
Almost immediately, however, that crystal began to yield. Classes of cases were excluded from Chevron's reach, and the court chipped away at its power and predictability by increasing the range of cases that judges (or at least Justices) could decide. This process of muddying accelerated in the early 2000s, most notably with the announcement of the "major questions" doctrine in Brown \& Williamson. It has only accelerated since.

Today, agency statutory interpretations appear to get no meaningful deference at all at the Supreme Court (though deference remains robust in the lower courts, for now). Agencies have prevailed in only three of the last 15 Chevron cases, and none in the last three years. In only one case over that period did the Court actually defer to an agency interpretation. That holding prompted a Justice to call for Chevron to be overturned. Two or possibly three further Justices have since called for the doctrine to be substantially narrowed or rejected entirely, and similar voices outside the Court have increased in volume. Deference is dead at the Court; indeed it has been on life support for some time, possibly since Brown \& Williamson two decades ago.

Chevron's decline is driven in large part by a wider ideological project skeptical of administrative authority, and may also be a side-effect of the rise to dominance of textualism over the same time period. But Chevron, like all crystalline doctrines, was inherently unstable from the beginning. It's decline should come as no surprise. Adrian Vermeule has argued that the long arc of administrative law bends towards deference (and that this is a defining positive feature). ${ }^{376} \mathrm{He}$ may be right over the long term, but if so we are currently in a reactionary moment. Whether this is good or bad depends on one's policy and institutional priors, and on how the Court rules in unknown future cases. Just because deference is unavailable doesn't mean agencies always lose, as King v. Burwell illustrates.

For some, Chevron's decline in clarity and influence signal its imminent demise. Instead, however, it is likely to persist, at least in name. It remains influential on the lower courts. Even if there are sufficient votes on the Court to overturn it, Chevron's weakness means there is little reason for its opponents to spend the political and institutional capital to overturn it. It is far easier to just criticize Chevron in dissents (and concurrences in the judgment), discrediting it to the point it becomes a precedent litigants "hate to cite" and its remaining defenders on the Court are reluctant to use.

Chevron is therefore likely to persist indefinitely; not because it (or deference generally) are necessary or inevitable, but because it doesn't matter very much anymore at the Court. In the short term, its decline could be made obvious by a decision clearly stating its accumulated exceptions and restrictions, as the Court did for related Auer deference in $K i$ sor. It could even be relegated to a doctrine for the lower courts only.

The evolution of crystal to mud is predictable, but it is also cyclical. In the more distant future, deference doctrine is likely to be recrystallized and possibly restrengthened, shifting power back to agencies. But this seems like a distant prospect from today's perspective, likely requiring big changes in personnel on the court and wider shifts in American politics

${ }^{376}$ See generally VERMEULE, supra note 13. 
and policy. Until then, at least at the Supreme Court, deference is dead though Chevron lives. 